\title{
Pressure ulcer care in the Netherlands versus Germany 0-1: what makes the difference
}

Citation for published version (APA):

Meesterberends, E. (2013). Pressure ulcer care in the Netherlands versus Germany 0-1: what makes the difference. [Doctoral Thesis, Maastricht University]. Maastricht University. https://doi.org/10.26481/dis.20131219em

Document status and date:

Published: 01/01/2013

DOI:

10.26481/dis.20131219em

Document Version:

Publisher's PDF, also known as Version of record

\section{Please check the document version of this publication:}

- A submitted manuscript is the version of the article upon submission and before peer-review. There can be important differences between the submitted version and the official published version of record.

People interested in the research are advised to contact the author for the final version of the publication, or visit the DOI to the publisher's website.

- The final author version and the galley proof are versions of the publication after peer review.

- The final published version features the final layout of the paper including the volume, issue and page numbers.

Link to publication

\footnotetext{
General rights rights.

- You may freely distribute the URL identifying the publication in the public portal. please follow below link for the End User Agreement:

www.umlib.nl/taverne-license

Take down policy

If you believe that this document breaches copyright please contact us at:

repository@maastrichtuniversity.nl

providing details and we will investigate your claim.
}

Copyright and moral rights for the publications made accessible in the public portal are retained by the authors and/or other copyright owners and it is a condition of accessing publications that users recognise and abide by the legal requirements associated with these

- Users may download and print one copy of any publication from the public portal for the purpose of private study or research.

- You may not further distribute the material or use it for any profit-making activity or commercial gain

If the publication is distributed under the terms of Article $25 \mathrm{fa}$ of the Dutch Copyright Act, indicated by the "Taverne" license above, 


\section{PRESSURE ULCER CARE IN THE NETHERLANDS VERSUS GERMANY 0-1}

What makes the difference? 
(C) Copyright Esther Meesterberends, Maastricht 2013

ISBN 978-94-6191-937-3

Cover design: Jeroen Veraa

Layout: Tiny Wouters

Printing: Ipskamp Drukkers

The studies in this thesis have been supported by a grant from the Dutch Ministry of Health, Welfare and Sport (VWS).

Printing of this thesis was financially supported by CARE10 BV, ConvaTec, Mediq Combicare, Nefemed: Belangenorganisatie voor medische hulpmiddelen, Nutricia Research, PAUL HARTMANN B.V. and WCS Kenniscentrum Wondzorg. 


\title{
PRESSURE ULCER CARE IN THE NETHERLANDS VERSUS GERMANY 0-1 What makes the difference?
}

\author{
PROEFSCHRIFT \\ ter verkrijging van de graad van doctor aan de Universiteit Maastricht \\ op gezag van de Rector Magnificus, Prof. dr. L.L.G. Soete, \\ volgens het besluit van het college van Decanen, \\ in het openbaar te verdedigen \\ op donderdag 19 december 2013 om 12.00 uur \\ door
}

Esther Meesterberends 


\section{Promotores}

Prof. dr. J.M.G.A. Schols

Prof. dr. C. Lohrmann (Medical University of Graz, Austria)

\section{Copromoter}

Dr. R.J.G. Halfens

Beoordelingscommissie

Prof. dr. J.P.H. Hamers (voorzitter)

Dr. G.J.J.W. Bours

Prof. dr. C. Lindholm (Sophiahemmet University Stockholm, Sweden)

Prof. dr. G. Meyer (Martin-Luther-University Halle-Wittenberg, Germany)

Prof. dr. T. van der Weijden 


\section{CONTENTS}

Chapter 1 General introduction

Chapter 2 Pressure ulcer guideline development and dissemination in Europe 25

Chapter $3 \quad$ Evaluation of the dissemination and implementation of pressure 41 ulcer guidelines in Dutch nursing homes

Chapter 4 The implementation of pressure ulcer guidelines in Dutch and German nursing homes: a qualitative study

Chapter 5 Pressure ulcer incidence in Dutch and German nursing homes: design of a prospective multicenter cohort study

Chapter $6 \quad$ Knowledge and use of pressure ulcer preventive measures in nursing homes: a comparison of Dutch and German nursing staff

Chapter 7 Do patients in Dutch nursing homes have more pressure ulcers than patients in German nursing homes? A prospective multi-center cohort study

Chapter 8 General discussion

Summary

Nederlandse samenvatting

Dankwoord

About the author 


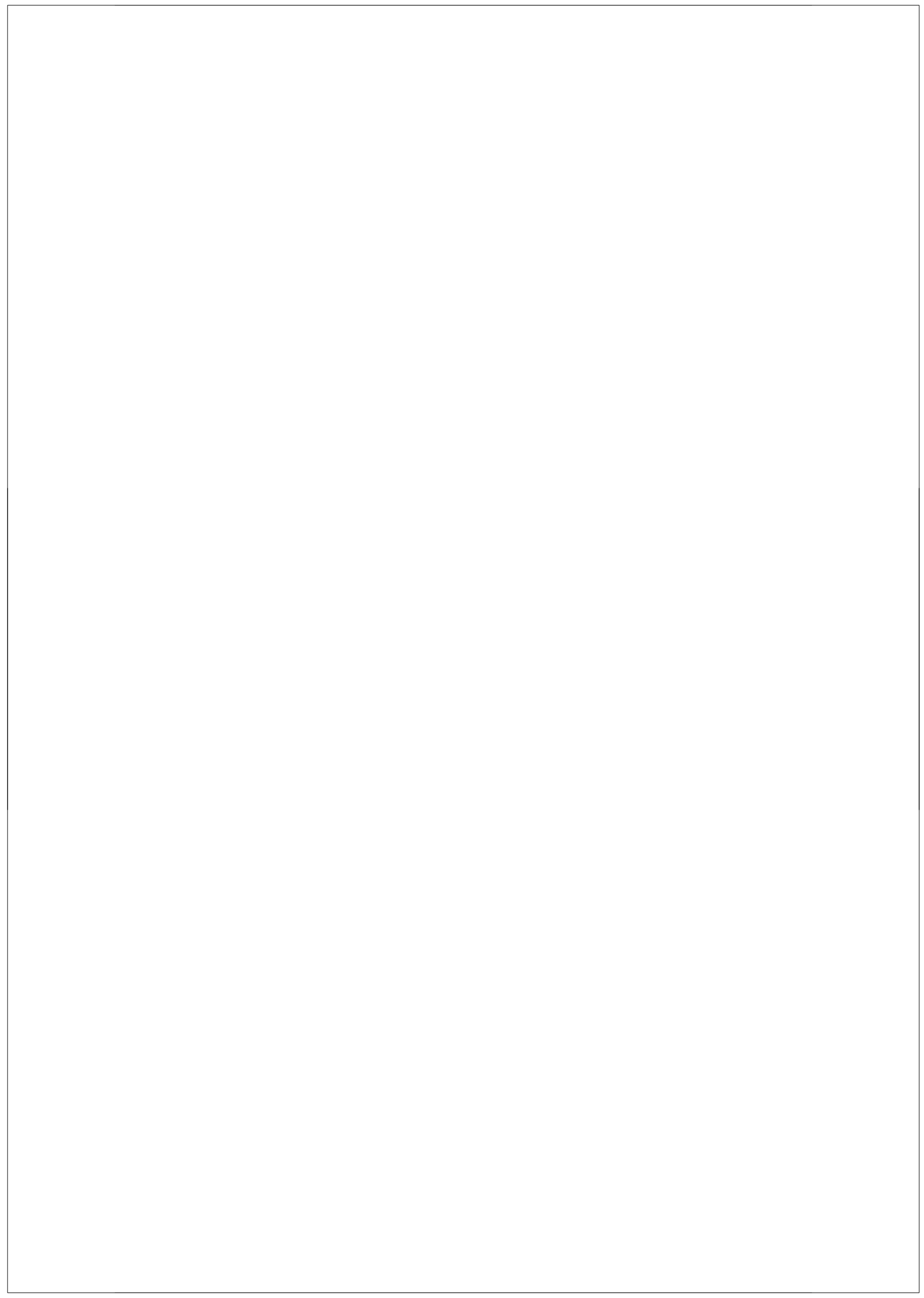




\section{CHAPTER 1}

GENERAL INTRODUCTION 
Chapter 1 


\section{GENERAL INTRODUCTION}

Pressure ulcers, also commonly referred to as pressure sores, decubitus ulcers or simply decubitus, are a common and serious health care problem in nursing homes. ${ }^{1-3}$ Pressure ulcers can have serious consequences. They cause a major burden in terms of patient suffering and frustration ${ }^{4,5}$ and can result in decreased quality of life, increased morbidity and mortality rates, an increased need for intensive nursing and medical care, an increased workload for healthcare workers and, as a consequence, increased healthcare costs. $^{5-9}$

A pressure ulcer is defined as 'a localised injury to the skin and/or underlying tissue usually over a bony prominence, as a result of pressure, or pressure in combination with shear'. ${ }^{10}$ Shear is described as 'a force that is applied to the body lateral to the surface of the skin; it is produced when adjacent surfaces slide across one another'. ${ }^{11}$ Both the intensity and the duration of pressure seem to play a role in the development of pressure ulcers. ${ }^{11,12}$ Pressure intensity is defined as the amount of external pressure exerted on internal tissues. ${ }^{11}$ The duration of the pressure is defined as the time at which external pressure is sustained by internal tissues ${ }^{11}$ and is influenced by the pain perception of the patient and by the degree to which the patient is able to react to this pain. ${ }^{12}$ The intensity and duration of pressure that can be tolerated without developing a pressure ulcer has also been studied. A parabolic relationship between the pressure intensity and duration has been demonstrated, with low pressure tolerated over longer time intervals and high pressure tolerated over much shorter times. ${ }^{13}$ In the presence of a shearing force, lower pressure may cause a pressure ulcer. ${ }^{14-16}$ Pressure and shear, by themselves, do not fully explain the formation of pressure ulcers. Other factors, known as risk factors, appear to play a part in the process. ${ }^{12,17}$ In 1970 , Lowthian introduced a new concept, namely tissue tolerance, also referred to as tissue viability. This concept includes a series of risk factors that are known to influence the risk of an individual patient for developing a pressure ulcer, without directly influencing the degree and the duration of pressure and/or shearing force. ${ }^{18}$ Although risk factors are at least as important as pressure and shearing force, ${ }^{19}$ they alone cannot cause a pressure ulcer; the existence of pressure and/or shearing force is needed. Tissue tolerance is seen as an intermediate variable and not as a causal factor. ${ }^{12}$ The precise amount and duration of pressure and shear necessary for pressure ulcer formation depends on the tissue tolerance of the individual, which may vary between persons. ${ }^{12,17}$

\section{Pressure ulcer prevalence and incidence in Dutch and German nursing homes}

Prevalence of pressure ulcers can be defined as the number of persons with pressure ulcers who exist in a patient population at a given point in time. ${ }^{20}$ The prevalence rate is influenced by the incidence rate as well as the healing time of the pressure ulcer. ${ }^{21}$ The healing time is influenced by treatment interventions. A distinction can be made between 
point prevalence, which is the prevalence measured at a certain point in time, and period prevalence, which is the prevalence measured over a period of time. Incidence is defined as the number of patients who are initially pressure ulcer free, but develop a pressure ulcer within a particular time period in a particular population. ${ }^{20}$ The incidence rate is influenced by preventive interventions.

Studies around the world have reported large differences in pressure ulcer point prevalence rates in nursing homes, varying from $7.7 \%$ to $83.6 \% .^{1,22-27}$ In the Netherlands and Germany, annual pressure ulcer prevalence surveys have been conducted since 1998 (NL) and 2001 (GER) using the same standardised definitions, instruments and methodology. ${ }^{23,28}$ The results of these surveys reveal large differences in prevalence rates between both countries over the past ten years, especially in nursing homes. ${ }^{29-31}$ Prevalence rates in Dutch nursing homes (30.8\%) have been reported to be three times as high compared to German ones (8.3\%). ${ }^{31}$

When examining the differences in prevalence and incidence rates between the Netherlands and Germany, it is important to take into account all factors associated with the development of pressure ulcers. Earlier research has identified several care-related factors that can influence pressure ulcer prevalence rates. These can be divided into structural and process factors according to Donabedian's structure-process-outcome (SPO) model. ${ }^{32}$ This model is used as theoretical background for the studies in this thesis. The SPO model has been designed as a framework for quality assessment in which both the performances of practitioners as well as the contributions of patients and of the health care system are taken into account. Furthermore, detailed information is needed about the causal linkages among the structural attributes of the settings in which care occurs, the processes of care and the outcomes of care. ${ }^{33}$

'Structure' is described as the attributes of the care setting, 'process' is what is actually done in prevention and treatment and 'outcome' refers to the effects of care on patients' health status. ${ }^{33,34}$ In this thesis, outcome is referred to as pressure ulcer prevalence or incidence.

Figure 1.1 gives an overview of the model. These different perspectives will be described in the following sections.

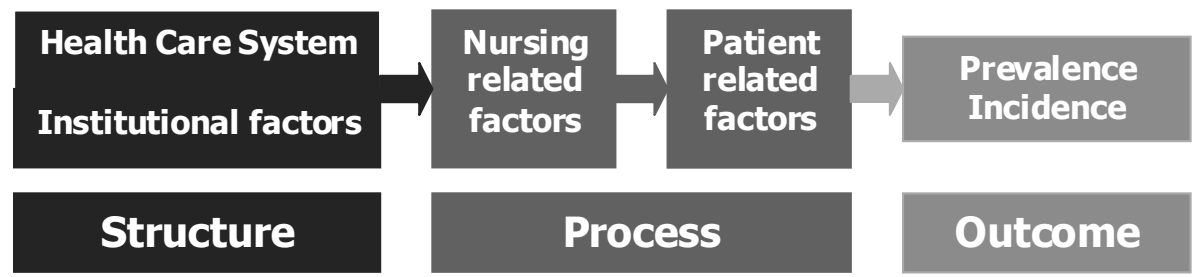

Figure 1.1 Factors influencing pressure ulcer prevalence and incidence rates (according to Donabedian's model) 


\section{Structural factors}

Structural factors are defined as the setting in which pressure ulcer prevention and treatment is provided. These include the following: the availability of pressure ulcer guidelines and pressure ulcer prevention and treatment material, education and staffing levels and qualifications.

\section{Pressure ulcer guidelines}

To address the prevention of pressure ulcers in a systematic way, pressure ulcer guidelines have been developed over the past decades at national ${ }^{35-37}$ and international level. ${ }^{10}$ To change clinical practice, these clinical pressure ulcer guidelines must be disseminated and implemented. Dissemination aims to influence practitioners' awareness, attitudes, knowledge, understanding and acceptance of the guideline ${ }^{38}$ and can be defined as 'the communication of information to care providers to increase their knowledge and skills'. ${ }^{103}$ skills'. ${ }^{39}$ After dissemination, the guideline needs to be implemented by introducing the innovation into daily care. This involves all activities that turn guidelines into action, influencing clinical decision making and behavior. ${ }^{39,40}$

The use of pressure ulcer guidelines is generally assumed to have several benefits, such as improving the quality, consistency and efficiency of patient care..$^{41-43}$ The implementation of a guideline is a difficult and complex process, as it depends on changing a variety of behaviours of health care staff. ${ }^{44}$ Therefore, the use of guidelines is not always reflected in the actual care that patients receive. ${ }^{45-50}$

\section{Staffing}

Pressure ulcer prevalence is one of the most sensitive quality indicators linked to staffing issues according to various studies. ${ }^{51-53}$ Numerous studies have associated staffing changes with changes in pressure ulcer development rates. ${ }^{52,54,55}$ Reduced staffing levels or changes to the staffing mix have also been associated with an increase in pressure ulcer prevalence rates and vice versa. ${ }^{53,55-60}$

\section{Nursing-related factors}

Besides structural factors, nursing-related preventive interventions are also linked to the development of pressure ulcers. Nursing-related preventive interventions include pressure ulcer risk assessment, skin inspection, nutritional screening, repositioning and the use of support surfaces. An adequate application of these preventive interventions is essential for providing good pressure ulcer care. Moreover, the non-application or use of non-recommended preventive measures may also lead to pressure ulcer development. Therefore, it is essential that the nursing staff have adequate knowledge about pressure ulcer preventive measures. 
Chapter 1

\section{Pressure ulcer risk assessment}

The prevention of pressure ulcers includes risk assessment. Risk can be examined by using a pressure ulcer risk assessment scale in combination with clinical judgment. There are several widely used risk assessment scales, such as the Waterlow pressure sore risk scale ${ }^{61}$ and the Braden scale. ${ }^{62}$ Individuals considered to be at risk of developing a pressure ulcer are, for example, those who are bedfast and/or chair fast and individuals with alterations to intact skin. ${ }^{63-65}$

\section{Skin inspection}

Another prevention component is the regular inspection of the skin for signs of redness in individuals identified as being at risk of pressure ulceration. ${ }^{10}$ Using skin emollients to hydrate dry skin is important in order to reduce the risk of skin damage. ${ }^{66}$

\section{Nutritional screening}

Screening patients' nutritional status is also very important in preventing pressure ulcers. A valid, reliable and practical tool should be used for nutritional screening. Several screening tools are available, like the Short Nutritional Assessment Questionnaire $(\mathrm{SNAQ})^{67,68}$, the Malnutrition Universal Screening Tool (MUST) ${ }^{69}$ and the Mini Nutritional Assessment (MNA). ${ }^{70}$ If the nutritional screening identifies individuals as being prone to develop pressure ulcers or to be malnourished or at nutritional risk, then a more comprehensive nutritional assessment should be undertaken by a registered dietician. ${ }^{10,71}$

\section{Repositioning}

Repositioning patients is another important component in preventing pressure ulcers and should be considered for all at-risk individuals. ${ }^{10}$ Repositioning should be undertaken to reduce the duration and magnitude of areas of the body that are vulnerable to pressure ulcers. $^{2,72,73}$ The frequency of repositioning will be influenced by the support surface in use. ${ }^{72}$ Furthermore, variables such as the individual's tissue tolerance, level of activity and mobility and general medical condition will influence the frequency of repositioning. ${ }^{10}$ Moreover, the time an individual spends seated in a chair without pressure relief should be limited. $^{74}$

\section{Support surfaces}

The use of support surfaces, like mattresses, beds, seats and cushions, are also useful in preventing pressure ulcers. When frequent manual repositioning is not possible, an active support surface (overlay or specific static or dynamic anti-pressure ulcer mattress) should be used for patients at higher risk of pressure ulcer development. ${ }^{73,75,76}$ 


\section{Patient-related factors}

Besides structural factors and nursing-related factors, many patient-related factors are linked to the development of pressure ulcers. These patient-related factors can be clustered in the following sub sections: demographic characteristics, functional status, medical condition, disease-related nutritional status, incontinence/ moisture, and hospitalization or nursing home (re)admission.

\section{Demographic characteristics}

Older age has been confirmed by numerous studies to be one of the best predictors for pressure ulcer development. ${ }^{77-80}$ An increasing age has several consequences that negatively influence the capacity of tissue to distribute pressure. Examples are the loss of sub-cutaneous fat, a reduction in skin elasticity and a general slowing down of the tissue repair mechanism. ${ }^{12,81}$ Furthermore, a number of studies have acknowledged that a history of pressure ulcers places persons at a higher risk for developing a pressure ulcer in the future. ${ }^{17,82,83}$

\section{Functional status}

Numerous studies have reported mobility, which is referred to as the ability to turn and move around in bed, as a relevant and important factor linked to the development of pressure ulcers. ${ }^{11,84,85}$ Mobility limitations, dependency in mobility and immobility have all been linked to a higher risk for pressure ulcer development by quite a few studies. ${ }^{86-89} \mathrm{~A}$ factor closely related to mobility is activity. This refers to the ability to get out of bed, and to reduce the effects of pressure on the skin by standing or walking and removing all pressure from non-weight bearing surfaces or shifting weight bearing to different pressure points while sitting. Activity has been stated by many authors as a risk factor for pressure ulcer development. ${ }^{11,84,90}$ Patients who are limited in their activity, for instance, because they are confined to bed, spend long periods sitting in a chair or have difficulty with ambulation, are at significantly greater risk for developing a pressure ulcer. ${ }^{87,91,92}$

\section{Medical condition}

The medical condition of patients can influence the development of pressure ulcers. Several medical conditions have been shown to be closely linked with a higher risk for pressure ulcer development, including the following: diabetes mellitus ${ }^{89,93,94}$, spinal cord injury $^{17,95,96}$, hip or other types of fractures ${ }^{89,97,98}$, orthopaedic surgery ${ }^{83}$, Alzheimer disease $^{91}$ and cardiovascular instability. ${ }^{99,100}$ The severity of illnesses is also linked to a higher pressure ulcer risk. ${ }^{1,101,102}$ Furthermore, infection has also been linked to pressure ulcer development. ${ }^{79}$

Numerous studies have indicated impairments as a risk factor for pressure ulcer development. A deviation could be made into cognitive impairments ${ }^{83,102}$; neurological impairments $^{91,96}$ and sensory impairments, for example, sensory loss due to conditions 
such as spinal cord injury; brain damage and diabetic neuropathy. ${ }^{103-105}$ Furthermore, quite a few studies have indicated altered consciousness, induced by a disease or specific medication like sedatives and anaesthetics, to be a pressure ulcer risk factor. ${ }^{11,87,99}$ Altered consciousness may be induced by a disease or by specific medication, such as sedatives, analgesics and anaesthetics. ${ }^{11}$

Circulatory disturbances can also influence the development of pressure ulcers. Several studies regard a low blood pressure as a risk factor. ${ }^{85,90,106}$ Besides blood pressure, several studies have associated an impaired blood flow and lower hemoglobin levels with an increased pressure ulcer risk. ${ }^{83,89,107}$

\section{Disease-related nutritional status}

Being underweight has been acknowledged to increase the risk for pressure ulcer development. ${ }^{92,108-110}$ Malnutrition, referred to as an impaired nutritional intake, has also been identified by numerous studies as a risk factor. ${ }^{83,90,111}$ Malnutrition is known to prolong wound healing. ${ }^{17,112}$ Body weight influences the intensity of pressure. Higher peak pressures were measured in persons with a low body weight compared with those of normal weight. ${ }^{12,109,113}$ Many studies have found a decrease in body weight to be a risk factor for pressure ulcer development. ${ }^{88,106,114}$ Furthermore, several studies have linked a lower serum albumin to pressure ulcer development. ${ }^{90,113,115}$

Besides nutritional status, dehydration is also associated with an increased pressure ulcer risk. $^{82,94,116}$ Dehydration decreases skin elasticity and increases the capacity for deformation of the tissue, which increases the risk of tissue damage. ${ }^{12}$

\section{Incontinence/moisture}

Skin moisture, a concept also used in several currently utilized pressure ulcer risk assessment scales, is known to be a risk factor for pressure ulcer development. ${ }^{105,116,117}$ Several studies have associated both urinary incontinence $54,80,87,118$ and fecal incontinence ${ }^{93,98,119,120}$ with an increased risk for pressure ulcer development. In contrast, several studies have also associated dry skin with pressure ulcer development. ${ }^{17,108,121}$

\section{Hospitalisation/nursing home (re)admission}

Quite a few studies have associated the time of hospitalization with pressure ulcer development. ${ }^{79,85,87,122}$ Furthermore, readmissions to a nursing home or hospital, nursing home residence prior to hospital admission and hospital residence prior to nursing home admission are found to be risk factors for pressure ulcer development. ${ }^{82,92,123}$

All patient-related risk factors described increase the individual probability of developing a pressure ulcer as well as the vulnerability of a defined population, for example, for predicting the expected prevalence or incidence in a population under risk. 
In summary, the literature has identified numerous factors related to nursing home structure, nursing staff and nursing home residents that can influence pressure ulcer prevalence and incidence rates. Nevertheless, it is not yet clear which combination of these factors leads to higher or lower rates, since most studies focus on one of these aspects, rather than investigating both process and structural factors.

In order to be able to explain the differences in pressure ulcer prevalence rates between the Netherlands and Germany, both process and structural factors have to be examined.

\section{AIMS AND OUTLINES OF THE THESIS}

\section{Aims}

This main objective of this thesis is to investigate the differences in pressure ulcer care between nursing homes in the Netherlands and Germany by measuring the incidence of pressure ulcers and possible related factors with respect to the nursing home residents, the nursing care provided and attributes of the care setting, such as the availability and implementation of a pressure ulcer guideline. The aims of this thesis are as follows:

1. To investigate the process of pressure ulcer guideline development and dissemination in six European countries.

2. To assess the process of pressure ulcer guideline implementation in Dutch and German nursing homes.

3. To assess nursing staff's knowledge about pressure ulcer preventive strategies and nursing staff's preventive practice in nursing homes in the Netherlands and Germany.

4. To investigate the incidence of pressure ulcers in nursing homes in the Netherlands and Germany.

5. To identify patient-related, nursing-related and structural factors associated with pressure ulcer development.

\section{Outline}

Chapter 2 presents the results of a study that investigated the process of pressure ulcer guideline development and dissemination in six European countries (aim 1). Chapter 3 reports on the results of a qualitative study in which the implementation of pressure ulcer guidelines in Dutch nursing homes was explored (aim 2). Chapter 4 provides the results of a qualitative study that compared the process of pressure ulcer guideline implementation in Dutch and German nursing homes (aim 2). Chapter 5 describes the design of a prospective cohort study that investigates the incidence of pressure ulcers in Dutch and German nursing homes and possible explaining factors. It also describes the selection process of nursing homes and participants, measurements and procedures in detail (aims 4 and 5). Subsequently, Chapter 6 presents the results of a cross-sectional survey which was nested in the prospective cohort study described in Chapter 5, in which the knowledge and practice of nursing staff employed in Dutch and German nursing homes 
Chapter 1

was investigated (aim 3). Chapter 7 presents the main outcomes of the prospective study described in Chapter 5 (aims 4 and 5). Finally, Chapter 8 discusses the main findings and some theoretical and methodological considerations of the studies presented in this thesis. The chapter concludes with recommendations for clinical practice and recommendations for future research. 


\section{REFERENCES}

1. Horn SD, Bender SA, Ferguson ML, Smout RJ, Bergstrom N, Taler G, Cook AS, Sharkey SS, Voss AC. The national pressure ulcer long-term care study: pressure ulcer development in long-term care residents. Journal of the American Geriatrics Society 2004;52:359-367.

2. Vanderwee K, Clark M, Dealey C, Gunningberg L, Defloor T. Pressure ulcer prevalence in Europe: a pilot study. Journal of Evaluation in Clinical Practice 2007;13:227-235.

3. De Souza DM, De Gouveia Santos VL. Incidence of pressure ulcers in the institutionalized elderly. Journal of Wound, Ostomy and Continence Nursing 2010;37:272-276.

4. Health Council of the Netherlands. Pressure Ulcers. The Hague: Health Council of the Netherlands; 1999.

5. De Laat EHEW, Scholte op Reimer WJ, Van Achterberg T. Pressure ulcers: diagnostics and interventions aimed at wound-related complaints: a review of the literature. Journal of Clinical Nursing 2005;14:464-472.

6. Erwin-Toth P. Cost-effective pressure ulcer management in extended care. Ostomy Wound Management 1995;41:0889-5899.

7. Berlowitz DR, Brandeis GH, Anderson J, Du W, Brand H. Effect of pressure ulcers on the survival of long-term care residents. Journal of Gerontology: Medical Sciences 1997;52a:106-110.

8. Allman RM, Goode PS, Burst N, Bartolucci AA, Thomas DR. Pressure ulcers, hospital complications, and disease severity: impact on hospital costs and length of stay. Advances in Wound Care 1999;12:22-30.

9. Severens JL, Habraken JM, Duivenvoorden S, Frederiks CMA. The cost of illness of pressure ulcers in the Netherlands. Advances in Skin \& Wound Care 2002;15:72-77.

10. European Pressure Ulcer Advisory Panel and National Pressure Ulcer Advisory Panel. Prevention and treatment of pressure ulcers: quick reference guide. Washington DC: National Pressure Ulcer Advisory Panel; 2009.

11. Smith M. A comprehensive review of risk factors related to the development of pressure ulcers. Journal of Orthopaedic Nursing 2003;7:94-102.

12. Defloor T. The risk of pressure sores: a conceptual scheme. Journal of Clinical Nursing 1999;8: 206-216.

13. Reswick JB, Rogers J. Experience at Ranchos Los Amigos hospital with devices and techniques to prevent pressure sores. In Bedsore biomechanics. (Kenedi RM, Cowden JM, Scales JT, eds.), London: Macmillan Press, 1976:301-313.

14. Dinsdale SM. Decubitus ulcers: role of pressure and friction in causation. Archives of Physical Medicine and Rehabilitation 1974;55:147-152.

15. Bennett L, Lee BY. Pressure versus shear in pressure sore causation. In Chronic ulcers of the skin. (Lee BY, ed.), New York: McGraw-Hill, 1985:39-56.

16. Rowland J. Pressure ulcers: a literature review and a treatment scheme. Australian Family Physician 1993;22:1819-1827.

17. Grey JE, Harding KG, Enoch S. Pressure ulcers. British Medical Journal 2006;332:472-475.

18. Lowthian PT. Bedsores: the missing links? Nursing Times 1970;66:1454-1458.

19. Meijer JH, Germs PH, Schneider H, Ribbe MW. Susceptibility to decubitus ulcer formation. Archives of Physical Medicine and Rehabilitation 1994;75:318-323.

20. Cuddigan J, Ayello EA, Sussman C, Baranoski S. Pressure ulcers in America: prevalence, incidence, and implications for the future. Reston VA: National Pressure Ulcer Advisory Panel; 2001.

21. Rothman KJ. Epidemiology. An introduction. New York: Oxford University Press; 2002.

22. Shiels C, Roe B. Pressure sore care: a survey of residential and nursing homes for elderly people. Elderly Care 1998;10:30-34. 
23. Bours GJJW, Halfens RJG, Lubbers M, Haalboom JRE. The development of a national registration form to measure the prevalence of pressure ulcers in the Netherlands. Ostomy Wound Management 1999;45:28-40.

24. Gunningberg L. Risk, prevalence and prevention of pressure ulcers in three Swedish health-care settings. Journal of Wound Care 2004;13:286-290.

25. Landi F, Russo A, Danese P, Liperoti R, Barillaro C, Bernabei R, Onder G. Anemia status, hemoglobin concentration, and mortality in nursing home older residents. Journal of the American Medical Directors Association 2007;8:322-327.

26. Halfens R, Meesterberends E, Meijers JJM, Du Moulin MFMT, van Nie NC, Neyens JCL, Schols JMGA. Rapportage resultaten: Landelijke Prevalentiemeting Zorgproblemen 2011. Maastricht: Universiteit Maastricht; 2011.

27. Roberts R. Pressure sore care in Clwyd nursing homes. Journal of Wound Care 1994;3:385-387.

28. Dassen T, Petermann B, Heinze C, Lahmann N, Lohrmann C, Mertens E, Tannen A. Dekubitus, Sturzereignisse, Pflegeabhängigkeit: Prävalenzerhebung 2002. Berlin: Institut für Medizin/Pflegepädagogik und Pflegewissenschaft; 2002.

29. Tannen A, Bours G, Halfens R, Dassen T. A comparsion of pressure ulcer prevalence rates in nursing homes in the Netherlands and Germany, adjusted for population characteristics. Research in Nursing \& Health 2006;29:588-596.

30. Tannen A, Dassen T, Halfens R. Differences in prevalence of pressure ulcers between the Netherlands and Germany: associations between risk, prevention and occurrence of pressure ulcers in hospitals and nursing homes. Journal of Clinical Nursing 2008;17:1237-1244.

31. Tannen A, Dietz E, Dassen T, Halfens R. Explaining the national differences in pressure ulcer prevalence between the Netherlands and Germany: adjusted for personal risk factors and institutional quality indicators. Journal of Evaluation in Clinical Practice 2009;15:85-90.

32. Donabedian A. Criteria and standards for quality assessment and monitoring. Quality Review Bulletin 1986;12:99-108

33. Donabedian A. The quality of care. How can it be assessed? Journal of the American Medical Association 1988;260:1743-1748.

34. Donabedian A. Explorations in quality assessment and monitoring, volume I. The definition of quality and approaches to its assessment. Ann Arbour MI: Health Administration Press; 1980.

35. Centraal Begeleidingsorgaan voor de Intercollegiale Toetsing. Decubitus. Tweede herziening. Alphen aan den Rijn: Van Zuiden; 2002.

36. National Institute for Health and Clinical Excellence. Pressure ulcers: the management of pressure ulcers in primary and secondary care. London: National Institute for Health and Clinical Excellence; 2005.

37. Virani T, McConnell H, Lappan-Gracon S, Santos J, Schouten JM, Russell B, Scott C, Burris J, Powell K. Risk assessment \& prevention of pressure ulcers. Toronto: Registered Nurses Association of Ontario; 2005.

38. Field M, Lohr K. Clinical Practice Guidelines: Directions for a New Program. Washington DC: National Academy Press; 1990.

39. Davis DA, Taylor-Vaisey A. Translating guidelines into practice: a systematic review of theoretic concepts, practical experience and research evidence in the adoption of clinical practice guidelines. Canadian Medical Association Journal 1997;157:408-416.

40. Cheater FM, Closs SJ. The effectiveness of methods of dissemination and implementation of clinical guidelines for nursing practice: a selective review. Clinical Effectiveness in Nursing 1997;1:4-15.

41. Woolf SH, Grol R, Hutchinson A, Eccles M, Grimshaw J. Potential benefits, limitations, and harms of clinical guidelines. British Medical Journal 1999;318:527-530. 
42. Ayello E, Sibbald R. Preventing pressure ulcers and skin tears. In Evidence-based Geriatric Nursing Protocols for Best Practice. 3rd ed. (Capezuti E, Zwicker D, Mezey M, Fulmer T, eds.), New York: Springer Publishing Company, 2008:403-429.

43. Basinski AS. Evaluation of clinical practice guidelines. Canadian Medical Association Journal 1995;153:1575-1581.

44. Grimshaw JM, Thomas RE, MacLennan G, Fraser C, Ramsey CR, Vale L, Whitty P, Eccles MP, Matowe L, Shirran L, Wensing M, Dijkstra R, Donaldson C. Effectiveness and efficiency of guideline dissemination and implementation strategies. Health Technology Assessment 2004; 8:341-352.

45. Rizzuto C, Bostrom J, Suter WN, Chenitz WC. Predictors of nurses' involvement in research activities. Western Journal of Nursing Research 1994;16:193-204.

46. Michel Y, Sneed NV. Dissemination and use of research findings in nursing practice. Journal of Professional Nursing 1995;11:306-311.

47. Parahoo K. Barriers to, and facilitators of, research utilization among nurses in Northern Ireland. Journal of Advanced Nursing 2000;31:89-98.

48. Moore Z, Price P. Nurses' attitudes, behaviours and perceived barriers towards pressure ulcer prevention. Journal of Clinical Nursing 2004;13:942-951.

49. Paquay L, Wouters R, Defloor T, Buntinx F, Debaillie R, Geys L. Adherence to pressure ulcer prevention guidelines in home care: a survey of current practice. Journal of Clinical Nursing 2008;17:627-636.

50. Buss IC, Halfens RJG, Huijer Abu-Saad H, Kok G. Pressure ulcer prevention in nursing homes: views and beliefs of enrolled nurses and other health care workers. Journal of Clinical Nursing 2004;13:668-676.

51. Bates-Jensen BM, Schnelle JF, Alessi CA, Al-Samarrai NR, Levy-Storms L. The effects of staffing on in-bed times of nursing home residents. Journal of the American Geriatrics Society 2004;52 931-938.

52. Alexander GL. An analysis of nursing home quality measures and staffing. Quality Management in Health Care 2008;17:242-251.

53. Anderson RA, Hsieh PC, Su HF. Resource allocation and resident outcomes in nursing homes: comparisons between the best and worst. Research in Nursing \& Health 1998;21:297-313.

54. Bianchetti A, Zanetti O, Rozzini R, Trabucchi M. Risk factors for the development of pressure sores in hospitalized elderly patients: results of a prospective study. Archives of Gerontology and Geriatrics 1993;16:225-232.

55. Kramer AM, Fish R. The relationship between nurse staffing levels and the quality of nursing home care. Appropriateness of minimum nurse staffing ratios in nursing homes: Phase II final report. Cambridge: Abt Associates for the Centres and Medicare and Medical Services; 2001.

56. Bostick JE. Relationship of nursing personnel and nursing home care quality. Journal of Nursing Care Quality 2004;19:130-136.

57. Zhang $\mathrm{X}$, Grabowski DC. Nursing home staffing and quality under the nursing home reform act. The Gerontologist 2004;44:13-23.

58. Castle NG, Engberg J. Staff turnover and quality of care in nursing homes. Medical Care 2005; 43:616-626.

59. Hickey EC, Young GJ, Parker VA, Czarnowski EJ, Saliba D, Berlowitz DR. The effects of changes in nursing home staffing on pressure ulcer rates. Journal of the American Medical Directors Association 2005;6:50-53.

60. Lake ET, Cheung RB (2006) Are patient falls and pressure ulcers sensitive to nurse staffing? Western Journal of Nursing Research 28, 654-677.

61. Waterlow JA. Pressure sores: a risk assessment card. Nursing Times 1985;81:49-55.

62. Bergstrom N, Braden BJ, Laguzza A, Holman V. The Braden scale for predicting pressure sore risk. Nursing Research 1987;36:205-210. 
63. Hayes PA, Wolf ZR, McHugh MK. Effect of a teaching plan on a nursing staff's knowledge of pressure ulcer risk, assessment, and treatment. Journal of Nursing Staff Development 1994;10: 207-213.

64. Magnan MA, Maklebust J. The effect of web-based Braden Scale training on the reliability of Braden subscale ratings. Journal of Wound, Ostomy and Continence Nursing 2009;36:51-59.

65. Magnan MA, Maklebust J. The effect of web-based Braden scale training on the reliability and precision of Braden scale pressure ulcer risk assessments. Journal of Wound, Ostomy and Continence Nursing 2008;35:199-208.

66. Bou JE, Segovia GT, Verdu SJ, Nolasco BA, Rueda LJ, Perejamo M. The effectiveness of a hyperoxygenated fatty acid compound in preventing pressure ulcers. Journal of Wound Care 2005;14:117-121.

67. Ferguson M, Capra S, Bauer J, Banks M. Development of a valid and reliable malnutrition screening tool for adult acute hospital patients. Nutrition 1999;15:458-464.

68. Kruizenga HM, Seidell JC, de Vet HC, Wierdsma NJ, van Bokhorst-de van der Schueren MA. Development and validation of a hospital screening tool for malnutrition: the short nutritional assessment questionnaire (SNAQ). Clinical Nutrition 2005;24:75-82.

69. Elia M. Nutritional screening of adults: A multidisciplinary responsibility. Redditch: Malnutrition Advisory Group; 2003.

70. Rubenstein LZ, Harker JO, Salva A, Guigoz Y, Vellas B. Screening for undernutrition in geriatric practice: developing the short-form mini-nutritional assessment (MNA-SF). Journal of Gerontology Series A: Biological Sciences and Medical Sciences 2001;56:366-372.

71. Posthauer ME. The role of nutrition in wound care. Advances in Skin \& Wound Care 2006;19: 43-52.

72. Defloor T, De Bacquer D, Grypdonck MHF. The effect of various combinations of turning and pressure reducing devices on the incidence of pressure ulcers. International Journal of Nursing Studies 2005;42:37-46.

73. Vanderwee K, Grypdonck MHF, Defloor T. Effectiveness of an alternating pressure air mattress for the prevention of pressure ulcers. Age and Ageing 2005;34:261-267.

74. Gebhardt K, Bliss MR. Preventing pressure sores in orthopaedic patients: is prolonged chair nursing detrimental? Journal of Tissue Viability 1994;4:51-54.

75. Sanada H, Sugama J, Matsui $Y$, Konya C, Kitagawa A, Okuwa M, Omote S. Randomised controlled trial to evaluate a new double-layer air-cell overlay for elderly patients requiring head elevation. Journal of Tissue Viability 2003;13:112-121.

76. Van Leen M, Hovius S, Neyens J, Halfens R, Schols J. Pressure relief, cold foam or static air? A single center, prospective, controlled randomized clinical trial in a Dutch nursing home. Journal of Tissue Viability 2011;20:30-34.

77. Bergstrom N, Braden B. A prospective study of pressure sore risk among institutionalized elderly. Journal of the American Geriatrics Society 1992;40:747-758.

78. Halfens RJG, Van Achterberg T, Bal RM. Validity and reliability of the Braden scale and the influence of other risk factors: a multi-centre prospective study. International Journal of Nursing Studies 2000;37:313-319.

79. Bours GJJW, De Laat EH, Halfens RJG, Lubbers M. Prevalence, risk factors and prevention of pressure ulcers in Dutch intensive care units: results of a cross-sectional survey. Intensive Care Medicine 2001;27:1599-1605.

80. Shahin ES, Dassen T, Halfens RJ. Pressure ulcer prevalence in intensive care patients: a crosssectional study. Journal of Evaluation in Clinical Practice 2008;14:563-568.

81. Fletcher J. The principles of pressure sore prevention. Nursing Standard 1996;10:47-55.

82. Spector WD, Fortinsky RH. Pressure ulcer prevalence in Ohio nursing homes: clinical and facility correlates. Journal of Aging and Health 1998;10:62-80. 
83. Thomas DR. Prevention and management of pressure ulcers. Missouri Medicine 2007;104: 52-57.

84. Braden BJ, Bergstrom N. A conceptual scheme for the study of the etiology of pressure sores. Rehabilitation Nursing 1987;12:8-12.

85. Lindgren $\mathrm{M}$, Unosson M, Fredrikson M, Ek AC. Immobility: a major risk factor for development of pressure ulcers among adult hospitalized patients: a prospective study. Scandinavian Journal of Caring Sciences 2004;18:57-64.

86. Maklebust JA, Magnan MA. Risk factors associated with having a pressure ulcer: a secondary data analysis. Advances in Wound Care 1994;7:25-41.

87. Allman RM. Pressure ulcer prevalence, incidence, risk factors, and impact. Clinics in Geriatric Medicine 1997;13:421-436.

88. Berlowitz DR, Brandeis GH, Morris JN, Ash AS, Anderson JJ, Kader B, Moskowitz MA. Deriving a risk-adjustment model for pressure ulcer development using the Minimum Data Set. Journal of the American Geriatrics Society 2001;49:866-871.

89. Haleem S, Heinert G, Parker MJ. Pressure sores and hip fractures. Injury 2008;39:219-223.

90. Ek AC, Unosson M, Larsson J, Von Schenck H, Bjurulf P. The development and healing of pressure sores related to the nutritional state. Clinical Nutrition 1991;10:245-250.

91. Zulkowski K. MDS+ RAP items associated with pressure ulcer prevalence in newly institutionalized elderly: study I. Ostomy Wound Management 1998;44:40-53.

92. Baumgarten M, Margolis D, Gruber-Baldini AL, Zimmerman S, German P, Hebel JR, Magaziner J. Pressure ulcers and the transition to long-term care. Advances in Skin \& Wound Care 2003;16: 299-304.

93. Brandeis $\mathrm{GH}$, Heossain M, Morris JN, Lipsitz LA. A longitudinal study of risk factors associated with the formation of pressure ulcers in nursing homes. Journal of the American Geriatrics Society 1994;42:388-393.

94. Casimiro C, Garcia de Lorenzo A, Usan L. Prevalence of decubitus ulcer and associated risk factors in an institutionalized Spanish elderly population. Nutrition 2002;18:408-414.

95. Krause JS. Skin sores after spinal cord injury: relationship to life adjustment. Spinal Cord 1998; 36:51-56.

96. Salzberg CA, Byrne DW, Kabir R, Van Niewerburgh P, Cayten CG. Predicting pressure ulcers during initial hospitalization for acute spinal cord injury. Wounds 1999;11:45-57.

97. Bergquist $\mathrm{S}$, Frantz R. Pressure ulcers in community-based older adults receiving home health care: prevalence, incidence, and associated risk factors. Advances in Wound Care 1999;12: 339-351.

98. Baumgarten M, Margolis D, Berlin JA, Strom BL, Garino J, Kagan SH, Kavesh W, Carson JL. Risk factors for pressure ulcers among elderly hip fracture patients. Wound Repair and Regeneration 2003;11:96-103.

99. Boyle M, Green M. Pressure sores in intensive care: defining their incidence and associated factors and assessing the utility of two pressure sore risk assessment tools. Australian Critical Care 2001;14:24-30

100. Capon A, Pavoni N, Mastromattei A, Di Lallo D. Pressure ulcer risk in long-term units: prevalence and associated factors. Journal of Advanced Nursing 2007;58:263-272.

101. Pieper B, Sugrue M, Weiland M, Spraque K, Heiman C. Risk factors, prevention methods, and wound care for patients with pressure ulcers. Clinical Nurse Specialist 1998;12:7-12.

102. Horn SD, Bender SA, Bergstrom N, Cook AS, Ferguson ML, Rimmasch HL, Sharkey SS, Smout RJ, Taler GA, Voss AC. Description of the national pressure ulcer long-term care study. Journal of the American Geriatrics Society 2002;50:1816-1825.

103. Carlson EV, Kemp MG, Shott S. Predicting the risk of pressure ulcers in critically ill patients. American Journal of Critical Care 1999;8:262-269. 
104. Gebhardt K. Pressure ulcer prevention. Part 1: Causes of pressure ulcers. Nursing Times 2002; 98:41-44.

105. Fisher AR, Wells G, Harrison MB. Factors associated with pressure ulcers in adults in acute care hospitals. Advances in Skin \& Wound Care 2004;17:80-90.

106. Nixon J, Cranny G, Bond S. Skin alterations of intact skin and risk factors associated with pressure ulcer development in surgical patients: a cohort study. International Journal of Nursing Studies 2007;44:655-663.

107. Olson B, Langemo D, Burd C, Hanson D, Hunter, Cathcart-Silberberg T. Pressure ulcer incidence in an acute care setting. Wound Care 1996;23:15-22.

108. Allman RM, Goode PS, Patrick MM, Burst N, Bartolucci AA. Pressure ulcer risk factors among hospitalized patients with activity limitation. Journal of the American Medical Association 1995;273:865-870.

109. VanGilder C, Macfarlane G, Meyer S, Lachenbruch C. Body Mass Index, weight, and pressure ulcer prevalence: an analysis of the 2006-2007 international pressure ulcer prevalence surveys. Journal of Nursing Care Quality 2009;24:127-135.

110. Shahin ES, Meijers JM, Schols JM, Tannen A, Halfens RJ, Dassen T. The relationship between malnutrition parameters and pressure ulcers in hospitals and nursing homes. Nutrition 2010;26:886-889.

111. Lindgren $M$, Unosson $M$, Krantz AM, Ek AC. Pressure ulcer risk factors in patients undergoing surgery. Journal of Advanced Nursing 2005;50:605-612.

112. Harris $\mathrm{CL}$, Fraser $\mathrm{C}$. Malnutrition in the institutionalized elderly: the effects on wound healing. Ostomy Wound Management 2004;50:54-63.

113. Uzun O, Tan M. A prospective, descriptive pressure ulcer risk factor and prevalence study at a university hospital in Turkey. Ostomy Wound Management 2007;53:44-56.

114. Flanagan M. Predicting pressure sore risk. Journal of Wound Care 1993;2:215-218.

115. Reed RL, Hepburn K, Adelson R, Center B, McKnight P. Low serum albumin levels, confusion, and fecal incontinence: are these risk factors for pressure ulcers in mobility-impaired hospitalized adults? Gerontology 2003;49:255-259.

116. Lindholm C, Sterner E, Romanelli M, Pina E, Torra y Bou J, Hietanen H, livanainen A, Gunningberg L, Hommel A, Klang B, Dealey C. Hip fracture and pressure ulcers: the PanEuropean Pressure Ulcer Study: intrinsic and extrinsic risk factors. International Wound Journal 2008;5:315-328.

117. Baldwin KM, Ziegler SM. Pressure ulcer risk following critical traumatic injury. Advances in Wound Care 1998;11:168-173.

118. Schue RM, Langemo DK. Prevalence, incidence, and prediction of pressure ulcers on a rehabilitation unit. Journal of Wound, Ostomy and Continence Nursing 1999;26:121-129.

119. Keller BPJA, Wille J, van Ramshorste B, van der Werken C. Pressure ulcers in intensive care patients: a review of risks and prevention. Intensive Care Medicine 2002;28:1379-1388.

120. Achterberg WP, Frijters DH, Ribbe MW. Het vóórkomen van ulcera in verpleeghuizen. Tijdschrift voor Gerontologie en Geriatrie 2008;39:115-121.

121. Baumgarten M, Margolis DJ, Localio AR, Kagan SH, Lowe RA, Kinosian B, Holmes JH, Abbuhl SB, Kavesh W, Ruffin A. Pressure ulcers among elderly patients early in the hospital stay. Journals of Gerontology. A: Biological Sciences and Medical Sciences 2006;61:749-754.

122. Gallagher P, Barry P, Hartigan I, McCluskey P, O'Connor K, O'Connor M. Prevalence of pressure ulcers in three university teaching hospitals in Ireland. Journal of Tissue Viability 2008;17: 103-109.

123. Keelaghan E, Margolis D, Zhan M, Baumgarten M. Prevalence of pressure ulcers on hospital admission among nursing home residents transferred to the hospital. Wound Repair and Regeneration 2008;16:331-336. 


\section{CHAPTER 2}

PRESSURE ULCER GUIDELINE DEVELOPMENT AND DISSEMINATION IN EUROPE 


\section{ABSTRACT}

Aims and objectives. To explore the current state of pressure ulcer guideline development and dissemination, from national to local level (i.e. nursing homes) in six European countries: England, Germany, Italy, the Netherlands, Portugal and Sweden.

Background. Pressure ulcers are a persistent problem in healthcare institutions. Their prevalence is influenced by many factors, one of them being the development and dissemination of pressure ulcer guidelines. These are difficult and complex processes, and it is not clear whether they differ between European countries.

Design. Literature review and semi-structured interviews.

Method. Interviews were conducted in six countries at national and nursing home level.

Results. Four countries had national pressure ulcer prevention and treatment guidelines. Portugal had no national guidelines and Sweden had shifted the responsibility to regional level. All participating nursing homes had pressure ulcer guidelines except those in Portugal. Control and monitoring of guideline dissemination was carried out only in Sweden and England.

Conclusions. All countries studied have national or regional pressure ulcer prevention and treatment guidelines, except Portugal. Portugal is also the only country where none of the nursing homes included had pressure ulcer guidelines. Because the dissemination of such guidelines does not imply actual implementation, further research should focus on the implementation process.

Relevance to clinical practice. Clinical guidelines, like pressure ulcer guidelines, are important tools in guiding the care processes in healthcare institutions. Successful dissemination of guidelines from national level to individual healthcare institutions is a first and necessary step in actually applying them. Monitoring of the guideline dissemination process is therefore essential. 


\section{INTRODUCTION}

Pressure ulcers are a persistent problem in healthcare institutions. They cause a major burden in terms of patient suffering and frustration ${ }^{1,2}$ and can result in decreased quality of life, increased morbidity and mortality rates, more intensive nursing and medical care, increased workload for healthcare workers and, as a consequence, increased healthcare costs. $^{3-7}$ Comparing international data on pressure ulcer prevalence rates in healthcare institutions show that these rates vary between countries from $3-83,6 \% .^{8-15}$ In Europe, large differences in pressure ulcer prevalence rates are also present, especially in nursing homes; however, these rates have not been studied extensively. Pressure ulcer prevalence rates in English nursing homes have been reported by two studies. Roberts (1994) found a prevalence rate of $7.5 \%{ }^{16}$; Shiels \& Roe (1998) found a rate of $7.9 \% .{ }^{17}$ In Italy, Landi et al. (2007) reported a nursing home pressure ulcer prevalence rate of $23 \% .{ }^{18}$ A Swedish study revealed a rate of $20 \%$ in a nursing home in $2002 .{ }^{19}$ Annual comparable pressure ulcer prevalence studies performed in Germany and the Netherlands reveal large differences in nursing home prevalence rates. In 2006, pressure ulcer prevalence in nursing homes was $24.2 \%$ in the Netherlands and $8.3 \%$ in Germany. ${ }^{14,15}$

Previous research shows that pressure ulcer onset is caused and influenced by many factors, which can be divided into structural, process and outcome factors. Although some research has been conducted into the differences in outcome factors in various countries $^{20,21}$, no comparison related to structural factors has yet been undertaken. This study focuses on an important structural aspect: the development and dissemination of national, regional and institutional pressure ulcer guidelines. The use of pressure ulcer guidelines is generally assumed to have several benefits, such as improvement of the quality, consistency and efficiency of patient care. ${ }^{22-26}$

Developing a good clinical guideline involves several steps. First, the need, goals and scope of the guideline must be formulated. A multidisciplinary panel must be formed to actually develop the guideline and the target audience has to be identified. A systematic literature review must be carried out to base the guideline on the best available evidence. Recommendations can then be formulated and the guideline drawn up. ${ }^{27-31}$

To change clinical practice, these kinds of clinical pressure ulcer guidelines must then be disseminated. Dissemination aims to influence practitioners' awareness, attitudes, knowledge, understanding and acceptance of the guideline ${ }^{32,33}$ and can be defined as 'the communication of information to care providers to increase their knowledge and skills'. ${ }^{34}$ Several strategies can be used to disseminate clinical guidelines, some of them more effective than others. ${ }^{30,35,36}$ A dissemination strategy shown to be generally effective is the use of reminder systems. ${ }^{34,37,38}$ Strategies that have shown variable effectiveness are audits, feedback, local consensus processes, educational outreach visits, patient-mediated interventions and the use of mass media. Passive implementation strategies, like educational materials alone, written materials, mailed materials and conferences, have shown little to no effect in changing practices. ${ }^{34,37-41}$ 
Clearly, disseminating guidelines is a difficult and complex process, therefore the use of guidelines is not always reflected in the actual care patients receive. ${ }^{42-47}$ Several studies in Europe have reported that pressure ulcer guidelines have not been disseminated and implemented within nursing homes. A 2002 study in Sweden revealed that, in a nursing home, mattresses and a turning schedule were used in only $11.1 \%$ of cases, and $53.4 \%$ of seated patients were repositioned. ${ }^{19}$ In England, Clark (2003) examined the extent of implementation of wound care guidelines. ${ }^{48}$ The results revealed that $88 \%$ of the respondents worked in an environment that had implemented wound care guidelines, but only in $18.3 \%$ of cases were the guidelines fully implemented. A report from the Dutch healthcare inspection in 1999 concluded that the existing pressure ulcer guidelines were not implemented and followed in practice because of a lack of pressure ulcer knowledge by nurses and doctors. ${ }^{1}$ Another Dutch study revealed that only $53 \%$ of the patients were positioned on a support surface when necessary, $33.6 \%$ of all pressure ulcers were dressed as recommended and less than one third of the patients received pressure ulcer education. $^{49}$

It is not yet clear whether there are differences in the development and dissemination of pressure ulcer guidelines between European countries and where any potential differences (and similarities) occur. Therefore, the aim of this study is to explore the current state of pressure ulcer guideline development and dissemination, from national to local level (i.e. nursing homes) in six European countries: England, Germany, Italy, the Netherlands, Portugal and Sweden. These six countries have been chosen due to their variance in pressure ulcer prevalence rates according to the studies mentioned earlier ${ }^{12,14-}$ 19 , their variety in nursing cultures and because they represent Europe from north to south.

The following research questions have been formulated:

1. Which national organisations are involved in the development and dissemination of pressure ulcer guidelines for nursing homes in England, Germany, Italy, the Netherlands, Portugal and Sweden?

2. How are pressure ulcer guidelines developed and disseminated to nursing homes by these national organisations in the six countries?

\section{METHODS}

\section{Design}

To obtain widespread insight into the national and local situations regarding pressure ulcer guideline development and dissemination, we chose to conduct semi-structured interviews both at national and nursing home level. The interview questions were based on relevant items found in the literature on guideline development, dissemination and implementation..$^{29,50-53}$ The instruments on which the questions are based are reliable and validated. 
The interviewees were asked open questions, which differed somewhat for the national organisations and the nursing homes. The national organisations were asked how they developed the guideline, who was involved, the strategies that were used to disseminate the guideline and the barriers that were faced during the development and dissemination processes. The interviewees in the nursing homes were asked if there was a pressure ulcer guideline at their nursing home and, if so, whether it was a nationally or regionally developed guideline and how they had received the guideline. If the nursing home had developed its own guideline, questions focused on the development process and the people involved in this process. Questions were also asked about how they disseminated the guideline in the nursing home and which barriers were perceived.

\section{Data collection}

Semi-structured interviews were held with a representative of the organisation responsible for national pressure ulcer guideline development in each country. This person had to have been involved in the guideline development process. The organisations were selected based on literature search; they were the Royal College of Nursing (RCN, England), the German Network for Quality development in Nursing (DNQP, Germany), the Nursing Association for the Study of Skin Wounds (A.I.S.Le.C., Italy), the Dutch Society of Nursing (V\&VN, the Netherlands), the Directorate-General of Health (DGS, Portugal) and the Swedish Council on Technology Assessment in Healthcare (SBU, Sweden).

To investigate the dissemination of the national pressure ulcer guideline to local level, semi-structured interviews were also held in three nursing homes in each country. Members of the European Pressure Ulcer Advisory Panel (EPUAP) were used as contact people, who randomly selected the three nursing homes in each country. In each nursing home interviews were held with a manager, a quality manager (or a department head) and a nurse to obtain comprehensive information. All interviewees agreed to participate and permission was given to audiotape the interview.

The interviews took place at the department of the national institution or in the nursing home. Most involved one interviewee and the researcher; when this was not possible the nursing home interviewees were interviewed together. The interviews were conducted in Dutch, English or German; when this was not possible, a translator was present during the interview. In total 51 interviews were conducted between June 2007-January 2008. Literal transcriptions were made, which were then sent back to the interviewees for comments. After processing these comments, a researcher (EM) ordered and analysed the transcribed interviews.

\section{Analysis}

Analysis started with reading through the data and applying codes to significant parts using the open coding method. Next, selective coding was used to distinguish relevant and less-relevant items. A classification scheme was developed to sort and organise the items 
by gathering individual items together into a smaller number of groups consisting of related items. The different classification groups were adapted to the data.

\section{RESULTS}

\section{National organisations responsible for guideline development and dissemination}

In England the Royal College of Nursing (RCN) was commissioned by the Department of Health in 1999 to develop a national pressure ulcer risk assessment and prevention guideline. The guideline was developed by a multidisciplinary team and based on a review of available evidence. The development team consisted of two groups: a technical group of evidence reviewers and an advisory group of nurses, doctors and physiotherapists. ${ }^{54}$ The guideline was published by the National Institute for Clinical Excellence (NICE) in 2001 and is available in two versions, one for nurses and one for patients. ${ }^{55,56}$ It was later revised $^{57}$, and the NICE subsequently published an 'all-in-one' guideline on pressure ulcer prevention and management in primary and secondary care which is summarised in a quick reference guide. ${ }^{58,59}$

In Germany, the German Network for Quality Development in Nursing (DNQP) began developing 'expert standards' for nursing in 1999. ${ }^{60,61}$ Expert standards are quite dissimilar to guidelines; they are described as the 'professional level of performance of nursing care $^{\prime 60}$ The development group is monodisciplinary. Its first expert standard, the 'National standard for the prevention of pressure ulcers in nursing', was published in 2000 and updated in 2004. ${ }^{60,61}$ Pressure ulcer care in Italy is issued by the Nursing Association for the Study of Skin Wounds (A.I.S.Le.C), which translated the US Agency for Health Care Policy Research pressure ulcer guideline into Italian in $1994{ }^{62,63}$ This version is currently in use in Italy.

The first national guidelines for pressure ulcer prevention and treatment in the Netherlands were drawn up in 1985 and 1986 by a panel of Dutch experts. ${ }^{64}$ They were revised twice over the following years. ${ }^{65,66}$

In Portugal, no national pressure ulcer guideline has yet been developed. Likewise, Sweden has no national pressure ulcer guidelines. ${ }^{67}$ The Swedish Society of Nurses has developed quality indicators for pressure ulcer prevention and treatment ${ }^{67,68}$, but these provide only general recommendations for pressure ulcer care. ${ }^{69}$

\section{National organisations guideline development and dissemination processes}

An overview of the guideline development processes of the interviewed national organisations can be seen in Table 2.1. The organisation involved for Sweden is not specifically responsible for developing guidelines, but performs systematic literature reviews on which local guidelines can be based. This process is also described in Table 2.1. Furthermore, people working at regional level in Sweden are responsible for developing 
pressure ulcer guidelines for their own regions and for disseminating them to nursing homes. All organisations interviewed have multidisciplinary guideline development groups, except in Germany. The guidelines for the organisations in England, Germany and the Netherlands all undergo an independent review before being published. The organisation in England uses public criticism by stakeholders, the German organisation a public consensus conference and the Dutch organisation an independent commission. The organisations in Portugal, Italy and Sweden do not have independent reviews before publication. Only the Dutch and German organisations pilot their guidelines before disseminating them. All organisations except the one in Italy have specifically set a date for updating their guidelines. Finally, all organisations receive funding by their respective governments to develop and disseminate their guidelines.

Table 2.1 Pressure ulcer guideline development.

\begin{tabular}{|c|c|c|c|c|c|c|}
\hline & England & Germany & Italy & the Netherlands & Sweden & Portugal \\
\hline $\begin{array}{l}\text { Multidisciplinary } \\
\text { development group }\end{array}$ & $x$ & & $x$ & $x$ & $x$ & \\
\hline $\begin{array}{l}\text { Mono disciplinary } \\
\text { development group }\end{array}$ & & $x$ & & & & \\
\hline $\begin{array}{l}\text { Independent review before } \\
\text { publication }\end{array}$ & $x$ & $x$ & & $x$ & & \\
\hline $\begin{array}{l}\text { Pilot before guideline } \\
\text { dissemination }\end{array}$ & & $x$ & & $x$ & & \\
\hline $\begin{array}{l}\text { Date for updating guideline } \\
\text { identified }\end{array}$ & $x$ & $\mathrm{x}$ & & $\mathrm{x}$ & $\mathrm{x}$ & \\
\hline $\begin{array}{l}\text { Funding for guideline } \\
\text { development and } \\
\text { dissemination }\end{array}$ & $x$ & $\mathrm{x}$ & $x$ & $x$ & $x$ & \\
\hline
\end{tabular}

The strategies used by the interviewed national organisations to disseminate their guidelines can be seen in Table 2.2. All use at least two strategies, but those in Germany and Sweden use the most - four in total. The most common strategies are use of the internet and presentation of the guideline at national or regional seminars or congresses. Table 2.2 also shows the barriers faced by the national organisations during the development and dissemination of their guidelines. The organisations in Italy and Sweden perceive the fewest barriers; those in Germany and the Netherlands perceive the most. The barrier mentioned most often is lack of money for dissemination. Finally, Table 2.2 also shows that all countries except Italy have at least one organisation responsible for healthcare control and hence also for the use and correct application of clinical guidelines.

\section{Guideline dissemination at local level}

The interviews in the nursing homes revealed that all have pressure ulcer guidelines except those in Portugal. The nursing homes in Germany, Italy and the Netherlands all use a derivative of the national pressure ulcer guideline. Those in England use a company developed pressure ulcer guideline. In Sweden, the nursing homes use the pressure ulcer 
Chapter 2

guideline developed by people at regional level who are responsible for developing and disseminating guidelines for their region. In the nursing homes in Italy and the Netherlands, the groups concerned with institutional pressure ulcer guidelines are multidisciplinary. In Germany, however, these groups consist of nursing personnel and a quality manager and involve no other disciplines. The people responsible for pressure ulcer guideline dissemination and implementation in the nursing homes differ for each country and institution. They include the quality manager, the region and/or location manager, the medical responsibility nurse (Sweden), the department head, the head nurse and other nurses. None of the nursing homes receive extra funding to disseminate and implement pressure ulcer guidelines.

Table 2.2 Pressure ulcer guideline dissemination.

\begin{tabular}{|c|c|c|c|c|c|c|}
\hline & England & Germany & Italy & the Netherlands & Sweden & Portugal \\
\hline \multicolumn{7}{|l|}{ Dissemination facilitators } \\
\hline \multicolumn{7}{|l|}{ Distribution to individual } \\
\hline Institutions & $x$ & & & $x$ & $x$ & \\
\hline Distribution to colleagues & & & $x$ & & & \\
\hline Internet & $x$ & $x$ & & $x$ & $x$ & \\
\hline Media & & $x$ & $x$ & & & \\
\hline Workshops/courses & & $x$ & $x$ & & $x$ & \\
\hline Seminars/congresses & & $x$ & $x$ & $x$ & $x$ & \\
\hline Sell the guideline & & $x$ & & & $x$ & \\
\hline \multicolumn{7}{|l|}{ Patient information } \\
\hline \multicolumn{7}{|l|}{ Dissemination \& } \\
\hline implementation surveys & $x$ & & & & $x$ & \\
\hline \multicolumn{7}{|l|}{ Nationally used } \\
\hline $\begin{array}{l}\text { monitoring/control } \\
\text { strategies }\end{array}$ & $x$ & $x$ & & $x$ & $\mathrm{x}$ & \\
\hline Total & 5 & 6 & 5 & 4 & 7 & 0 \\
\hline \multicolumn{7}{|l|}{ Dissemination barriers } \\
\hline Lack of time & & $x$ & & & & \\
\hline Lack of money & & $x$ & $x$ & $x$ & & \\
\hline Lack of personnel & & $x$ & & & & \\
\hline Lack of resources & $x$ & & & & & \\
\hline Changing behaviour & $x$ & & & & & \\
\hline Communication & & & & $x$ & & \\
\hline \multicolumn{7}{|l|}{ Resistance against the } \\
\hline Guideline & & & & $x$ & $x$ & \\
\hline Total & 2 & 3 & 1 & 3 & 1 & 0 \\
\hline \multirow{2}{*}{ Prevalence rates (\%) } & 7.5 (1994) & $8.3(2006)$ & 41.0 (1999) & $24.2(2006)$ & $20(2002)$ & - \\
\hline & 7.9 (1998) & & $23.0(2007)$ & & & \\
\hline
\end{tabular}




\section{DISCUSSION}

This study reveals a variety of similarities and differences in the development and dissemination of pressure ulcer guidelines in the six European countries. Only Portugal and Sweden do not have national pressure ulcer prevention and treatment guidelines. In Sweden, a national organisation carries out systematic literature reviews on which institutional pressure ulcer guidelines can be based. Further, people working at regional level in Sweden are responsible for developing pressure ulcer guidelines for their regions and disseminating them to the regional nursing homes. The interviews in the nursing homes revealed that Portugal is the only country where none of the interviewed homes have a pressure ulcer guideline. All other interviewed nursing homes have pressure ulcer guidelines.

The strategies used to disseminate the national pressure ulcer guidelines in the six countries differed in terms of number and type. Nevertheless, all national organisations used a multifaceted strategy. This has been recognised as a successful dissemination approach by some studies ${ }^{34,39}$, while others found it only as effective as single interventions. ${ }^{70}$ The use of reminder systems, which have been shown to be generally effective $\mathrm{e}^{34,37,38}$, were not used by any of the organisations.

To ensure successful dissemination of the national guideline to nursing homes, the process must be monitored and controlled. The interviews with the national organisations revealed that those in England, Germany, the Netherlands and Sweden used a national monitoring/control strategy for the dissemination and implementation of their guidelines. However, the nursing home interviews revealed that only in Sweden and England those monitoring strategies were actually carried out. In Sweden this was the responsibility of people at regional level, and in England of people at company level. In the other countries, none of the nursing home interviewees indicated that the dissemination and implementation of the pressure ulcer guideline in their home was controlled.

The number and type of barriers faced during the dissemination of the national guideline varied between the countries. When comparing the number of barriers and facilitators mentioned in each country, a correlation can be seen between a low number of barriers and a high number of facilitators, and vice versa. For example, the Dutch organisation faced the most barriers and used the fewest facilitators, while the Swedish organisation faced the fewest barriers and used the most facilitators.

Comparisons between the number of barriers and facilitators to the pressure ulcer prevalence rates in the literature revealed interesting results. Countries with high prevalence rates, like Sweden and Italy, faced the fewest barriers and used an average or high number of facilitators, while countries with a low prevalence rate like Germany faced the most barriers and used an average number of facilitators. The Netherlands, where a high prevalence rate was found, faced the most barriers and used the fewest facilitators. Because these conclusions are based on prevalence rates from the literature, it is not possible to generalise the results. Therefore, further research will compare the dissemination of pressure ulcer guidelines in nursing homes where prevalence rates are 
obtained via the same method. Furthermore, whether all barriers and facilitators are equally important - and if not, which are more important than others - remains unknown. For that reason, further research should also focus on these aspects.

Although dissemination of the pressure ulcer guideline is a necessary condition for its implementation, it does not imply that the guideline is actually implemented successfully within the nursing homes. Several studies found in the literature revealed information about unsuccessful implementation of pressure ulcer guidelines in nursing homes in the six European countries. ${ }^{1,19,45,48,49}$ Further research should therefore focus on the process of pressure ulcer guideline implementation in nursing homes in these countries.

\section{Limitations}

Some potential weaknesses of this study design should be addressed. First, the interviews were held in only a small number of nursing homes in each country (i.e. three). Further, the nursing homes were selected by the contact person in each country, which could have resulted in selection bias. Moreover, in some nursing homes interviews were held with a number of interviewees at once, which could have resulted in information bias. Similarly the interview performed with a translator could have resulted in information bias. Finally, the interviews were analysed by one person only.

\section{CONCLUSION}

This study has investigated the development and dissemination of pressure ulcer guidelines in six European countries, and found several similarities and differences between these processes. The development and dissemination has been successful in most cases, with the exception of Portugal, where no national guideline has been developed and none of the nursing homes had pressure ulcer guidelines. Differences in guideline dissemination occurred in terms of the number and type of strategies used and barriers faced. Monitoring of dissemination from national level to individual nursing homes was carried out only in Sweden and England. Because dissemination must be followed by implementation, further research should focus on investigating the implementation of the pressure ulcer guideline in nursing homes.

\section{RELEVANCE TO CLINICAL PRACTICE}

Clinical guidelines, like pressure ulcer guidelines, are important tools in guiding the care process in healthcare institutions. Successful dissemination of a pressure ulcer guideline from national level to individual healthcare institutions is a first and necessary step in actually applying the guideline. Therefore, monitoring of the guideline dissemination process is essential. Dissemination must also be followed by implementation to prevent and treat pressure ulcers according to guideline recommendations. 


\section{REFERENCES}

1. Health Council of the Netherlands. Pressure ulcers. The Hague: Health Council of the Netherlands; 1999.

2. De Laat EHEW, Scholte op Reimer WJ, Van Achterberg T. Pressure ulcers: diagnostics and interventions aimed at wound-related complaints: a review of the literature. Journal of Clinical Nursing 2005;14:464-472.

3. Haalboom J. De kosten van decubitus (The cost of pressure ulcers). Nederlands Tijdschrift voor Geneeskunde 1991;135:606-610.

4. Erwin-Toth P. Cost-effective pressure ulcer management in extended care. Ostomy Wound Management 1995;41:64S-69S.

5. Berlowitz DR, Brandeis GH, Anderson J, Du W, Brand H. Effect of pressure ulcers on the survival of long-term care residents. Journal of Gerontology: Medical Sciences 1997;52a:106-110.

6. Allman RM, Goode PS, Burst N, Bartolucci AA, Thomas DR. Pressure ulcers, hospital complications, and disease severity: impact on hospital costs and length of stay. Advances in Wound Care 1999;12:22-30.

7. Severens JL, Habraken JM, Duivenvoorden S, Frederiks CMA. The cost of illness of pressure ulcers in the Netherlands. Advances in Skin \& Wound Care 2002;15:72-77.

8. Allman RM, Laprade CA, Noel LB, Walker JM, Moorer CA, Dear MD, Smith CS. Pressure sores among hospitalized patients. Annals of Internal Medicine 1986;105:337-342.

9. Ek AC, Unosson M, Larsson J, Von Schenck H, Bjurulf P. The development and healing of pressure sores related to the nutritional state. Clinical Nutrition 1991;10:245-250.

10. Bours GJJW, Halfens RJG, Lubbers M, Haalboom JRE. The development of a national registration form to measure the prevalence of pressure ulcers in the Netherlands. Ostomy Wound Management 1999;45:28-40.

11. O'Dea K. The prevalence of pressure damage in acute care hospital patients in the UK. Journal of Wound Care 1999;8:192-194.

12. Bours $G$, Defloor $T$, Wansink S, Clark M. Summary report on pressure ulcer prevalence: data collected in Belgium, Italy, Portugal, Sweden and the United Kingdom over the 14th and 15th of November 2001. European Pressure Ulcer Advisory Panel; 2002.

13. Cuddigan J, Berlowitz D, Ayello E. Pressure ulcers in America: prevalence, incidence and implications for the future. Advances in Skin \& Wound Care 2001;14:208-215.

14. Dassen T, Petermann B, Heinze C, Lahmann N, Mertens E, Schmitz G, Tannen A, Wilborn D. Pflegeabhängigkeit, Sturzereignisse, Inkontinenz, Dekubitus: Prävalenz Erhebung 2006. Berlin: Charité Universität; 2006.

15. Halfens RJG, Janssen MAP, Meijers JMM. Rapportage resultaten: Landelijke Prevalentiemeting Zorgproblemen 2006. Maastricht: Maastricht University; 2006.

16. Roberts R. Pressure sore care in Clwyd nursing homes. Journal of Wound Care 1994;3:385-387.

17. Shiels C, Roe B. Pressure sore care: a survey of residential and nursing homes for elderly people. Elderly Care 1998;10:30-34.

18. Landi F, Russo A, Danese P, Liperoti R, Barillaro C, Bernabei R, Onder G. Anemia status, hemoglobin concentration, and mortality in nursing home older residents. Journal of the American Medical Directors Association 2007;8:322-327.

19. Gunningberg L. Risk, prevalence and prevention of pressure ulcers in three Swedish health-care settings. Journal of Wound Care 2004;13:286-290.

20. Tannen A, Bours G, Halfens R, Dassen T. A comparsion of pressure ulcer prevalence rates in nursing homes in the Netherlands and Germany, adjusted for population characteristics. Research in Nursing \& Health 2006;29:588-596. 
21. Tannen A, Dassen T, Halfens R. Differences in prevalence of pressure ulcers between the Netherlands and Germany: associations between risk, prevention and occurrence of pressure ulcers in hospitals and nursing homes. Journal of Clinical Nursing 2008;17:1237-1244.

22. Basinski AS. Evaluation of clinical practice guidelines. Canadian Medical Association Journal 1995;153:1575-1581.

23. Woolf SH, Grol R, Hutchinson A, Eccles M, Grimshaw J. Potential benefits, limitations, and harms of clinical guidelines. British Medical Journal 1999;318:527-530.

24. Registered Nurses' Association of Ontario. Risk assessment and prevention of pressure ulcers (Revised). Toronto: Registered Nurses' Association of Ontario; 2005.

25. Registered Nurses Association of Ontario. Assessment and management of stage I to IV pressure ulcers. Toronto: Registered Nurses Association of Ontario; 2007.

26. Ayello E, Sibbald R. Preventing pressure ulcers and skin tears. In Evidence-based Geriatric Nursing Protocols for Best Practice. 3rd ed. (Capezuti E, Zwicker D, Mezey M, Fulmer T, eds.) New York: Springer Publishing Company, 2008:403-429.

27. Grol R, Thomas S, Roberts R. Development and implementation of guidelines for family practice: lessons from The Netherlands [editorial]. Journal of Family Practice 1995;40:435-439.

28. Duff LA, Kitson AL, Seers K, Humphris D. Clinical guidelines: an introduction to their development and implementation. Journal of Advanced Nursing 1996;23:887-895.

29. National Health and Medical Research Council. A guide to the development, implementation and evaluation of clinical practice guidelines. Canberra: National Health and Medical Research Council; 1999.

30. National Health and Medical Research Council. How to put the evidence into practice: implementation and dissemination strategies. Canberra: National Health and Medical Research Council; 2000

31. Scottish Intercollegiate Guidelines Network. A guideline developers' handbook. SIGN publication No. 50. Edinburgh: Scottish Intercollegiate Guidelines Network; 2008.

32. Field M, Lohr K. Clinical Practice Guidelines: Directions for a New Program. Washington DC: National Academy Press; 1990.

33. Institute of Medicine. Clinical Practice Guidelines: Directions for a New Program. Washington DC, National Academy Press; 1990.

34. Davis DA, Taylor-Vaisey A. Translating guidelines into practice: a systematic review of theoretic concepts, practical experience and research evidence in the adoption of clinical practice guidelines. Canadian Medical Association Journal 1997;157:408-416.

35. DiCenso A, Virani T, Bajnok I, Borycki E, Davies B, Graham I, Harrison M, Logan J, McCleary L, Power M, Scott J. A toolkit to facilitate the implementation of clinical practice guidelines in healthcare settings. Hospital Quarterly 2002;5:55-60.

36. Grol R. Improving the quality of medical care: building bridges among professional pride, payer profit, and patient satisfaction. Journal of the American Medical Association 2001;286: 2578-2585.

37. Bero LA, Grilli R, Grimshaw JM, Harvey E, Oxman AD, Thomson MA. Closing the gap between research and practice: an overview of systematic reviews of interventions to promote the implementation of research findings. The Cochrane Effective Practice and Organization of Care Review Group. British Medical Journal 1998;317:465-468.

38. National Health Service Centre for Reviews and Dissemination. Getting evidence into practice. Effective Health Care 1999;5:1-16.

39. Oxman AD, Thomson MA, Davis DA, Haynes B. No magic bullets: a systematic review of 102 trials of interventions to improve professional practice. Canadian Medical Association Journa 1995;153:1423-1431.

40. Grimshaw J, Freemantle N, Wallace S, Russell I, Hurwitz B, Watt I, Long A, Sheldon T. Developing and implementing clinical practice guidelines. Quality in Health Care 1995;4:55-64. 
41. Feder G, Eccles M, Grol R, Griffiths C, Grimshaw J. Using clinical guidelines. British Medical Journal 1999;318:728-730.

42. Rizzuto C, Bostrom J, Suter WN, Chenitz WC. Predictors of nurses' involvement in research activities. Western Journal of Nursing Research 1994;16:193-204.

43. Michel Y, Sneed NV. Dissemination and use of research findings in nursing practice. Journal of Professional Nursing 1995;11:306-311.

44. Parahoo K. Barriers to, and facilitators of, research utilization among nurses in Northern Ireland. Journal of Advanced Nursing 2000;31:89-98.

45. Buss IC, Halfens RJG, Huijer Abu-Saad H, Kok G. Pressure ulcer prevention in nursing homes: views and beliefs of enrolled nurses and other health care workers. Journal of Clinical Nursing 2004;13:668-676.

46. Moore Z, Price P. Nurses' attitudes, behaviours and perceived barriers towards pressure ulcer prevention. Journal of Clinical Nursing 2004;13:942-951.

47. Paquay L, Wouters R, Defloor T, Buntinx F, Debaillie R, Geys L. Adherence to pressure ulcer prevention guidelines in home care: a survey of current practice. Journal of Clinical Nursing 2008;17:627-636.

48. Clark M. Barriers to the implementation of clinical guidelines. Journal of Tissue Viability 2003;13:62-72.

49. Bours GJJW, Halfens RJG, Huijer Abu-Saad H, Grol RTPM. Prevalence, prevention and treatment of pressure ulcers: descriptive study in 89 institutions in the Netherlands. Research in Nursing \& Health 2002;25:99-110.

50. Cluzeau F, Littlejohns P, Grimshaw J, Feder G. Appraisal instrument for clinical guidelines, version 1. London: St. George's Hospital Medical School; 1997.

51. Mäkelä $M$, Thorsen T. A framework for guideline implementation studies. In Changing Professional Practice: Theory and Practice of Clinical Guidelines Implementation (Thorsen T, Mäkelä M, eds.), Copenhagen: Danish Institute for Health Services; 1999.

52. The AGREE Collaboration. Development and validation of an international appraisal instrument for assessing the quality of clinical practice guidelines: the AGREE project. Quality and Safety in Health Care 2003;12:18-23.

53. Rogers EM. Diffusion of innovations, 4th edition. New York: The Free Press; 1995.

54. Rycroft-Malone J, Mclnnes E. Pressure ulcer risk assessment and prevention guideline: technical report. London; 2001.

55. National Institute for Health and Clinical Excellence. Pressure ulcer risk assessment and prevention - inherited clinical guideline B. London: National Institute for Health and Clinical Excellence; 2001.

56. National Institute for Health and Clinical Excellence. Pressure ulcer risk assessment and prevention. A guide for patients and their carers. London: National Institute for Health and Clinical Excellence; 2001.

57. National Institute for Health and Clinical Excellence. Pressure ulcer risk assessment and prevention and equipment selection. London: National Institute for Health and Clinical Excellence; 2003.

58. National Institute for Health and Clinical Excellence. How to put NICE guidance into practice. A guide to implementation for organizations. London: National Institute for Health and Clinical Excellence; 2005.

59. National Institute for Health and Clinical Excellence. Pressure ulcers: the management of pressure ulcers in primary and secondary care. London: National Institute for Health and Clinical Excellence; 2005.

60. Deutsches Netzwerk für Qualitätsentwicklung in der Pflege. Expertenstandard 'Dekubitusprophylaxe in der Pflege' Entwicklung- Konsentierung - Implementierung 2. Aufl. Osnabrück: Deutsches Netzwerk für Qualitätsentwicklung in der Pflege; 2002. 
61. Wilborn D, Halfens R, Dassen T. Pressure ulcer: prevention protocols and prevalence. Journal of Evaluation in Clinical Practice 2006;12:630-638.

62. Agency for Health Care Policy and Research. Pressure Ulcers in Adults: Prediction and Prevention. Clinical Practice Guideline No. 3 AHCPR Publication No. 92-0047. Rockville: Agency for Health Care Policy and Research; 1992.

63. Bellingeri A. Information on the Italian Nurses Cutaneous Wounds Association. European Wound Management Association Journal 2003;3:52.

64. Centraal Begeleidingsorgaan voor de Intercollegiale Toetsing. Consensus preventie van decubitus: Utrecht: Centraal Begeleidingsorgaan voor de Intercollegiale Toetsing; 1985.

65. Centraal Begeleidingsorgaan voor de Intercollegiale Toetsing. Herziening consensus decubitus. Utrecht: Centraal Begeleidingsorgaan voor de Intercollegiale Toetsing; 1992.

66. Centraal Begeleidingsorgaan voor de Intercollegiale Toetsing. Decubitus. Tweede herziening. Alphan aan den Rijn: Van Zuiden; 2002.

67. Gunningberg L. Are patients with or at risk of pressure ulcers allocated appropriate prevention measures? International Journal of Nursing Practice 2005;11:58-67.

68. Ek A-C, Nordström G, Berglund B. Quality indicators for patients with or with risk of developing pressure ulcers. In Quality Indicators in Nursing, 3rd edn. (Idvall E, ed.), Stockholm: Swedish Society of Nursing and Gothia, 2007:137-146.

69. Gunningberg L, Ehrenberg A. Accuracy and quality in the nursing documentation of pressure ulcers: a comparison of record content and patient examination. Journal of Wound, Ostomy and Continence Nursing 2004;31:328-335.

70. Grimshaw JM, Thomas RE, MacLennan G, Fraser C, Ramsay CR, Vale L, Whitty P, Eccles MP, Matowe L, Shirran L, Wensing M, Dijkstra R, Donaldson C. Effectiveness and efficiency of guideline dissemination and implementation strategies. Health Technology Assessment 2004;8:341-352. 


\section{CHAPTER 3}

EVALUATION OF THE DISSEMINATION AND IMPLEMENTATION OF PRESSURE ULCER GUIDELINES IN DUTCH NURSING HOMES 


\section{ABSTRACT}

Rationale, aims and objectives. Annual national pressure ulcer prevalence surveys have been conducted in the Netherlands over the past 10 years and have revealed high prevalence rates in Dutch nursing homes. Pressure ulcer guideline implementation is one of the factors that can influence prevalence rates. Previous research has shown that these guidelines are often only partly implemented in Dutch nursing homes. Reasons for this lack of pressure ulcer guideline implementation are not known. Therefore, the aim of this study is to investigate the current situation regarding pressure ulcer guideline dissemination and implementation in Dutch nursing homes.

Method. Semi-structured interviews were conducted in eight nursing homes in the Netherlands from June 2008 till March 2009. In each nursing home, interviews were held with eight persons.

Results. The implementation of pressure ulcer guidelines was lacking in some of the nursing homes. Risk assessment scales were often not used in practice, repositioning schemes were not always available and, when they were, they were often not used in practice. Knowledge about guideline recommendations was also lacking and pressure ulcer education was inadequate. Barriers to applying guideline recommendations in practice were mostly related to personnel and communication.

Conclusions. The implementation of pressure ulcer guidelines does not seem to be successful in all nursing homes and needs more attention. Barriers mentioned by the interviewees in applying guideline recommendations need to be addressed. Providing adequate education for nursing home staff and increasing attention for pressure ulcer care can be the first steps in improving the implementation of pressure ulcer guidelines. 


\section{INTRODUCTION}

Pressure ulcers have been a persistent care problem in all health care sectors in the Netherlands over the past decades. Pressure ulcers can result in a decreased quality of life, more intensive nursing and medical care and increased morbidity and mortality rates. $^{1,2}$ Since 1998, annual national prevalence surveys have been conducted in the Netherlands. ${ }^{3}$ Results of these surveys reveal high prevalence rates in Dutch nursing homes over the past 10 years compared with other health care settings. ${ }^{4,5}$ In 2008 the prevalence in nursing homes was $15.6 \%$ compared with $10.3 \%$ in general hospitals, $7.4 \%$ in homes for the elderly and $6.9 \%$ in home care. ${ }^{6}$ In order to initiate a decrease in these prevalence rates in nursing homes it is essential to know which factors may influence the onset of pressure ulcers. Previous research has recognised that pressure ulcer prevalence rates can be influenced by several care-related factors, which can be divided into structural, process and outcome factors. ${ }^{7}$ This study will focus on an important aspect of both structural and process factors, namely the dissemination and implementation of pressure ulcer guidelines. Dissemination can be defined as 'the communication of information to care providers to increase their knowledge and skills'. ${ }^{8}$ After dissemination, implementation has to take place, namely the introduction of an innovation in daily care, and it involves all activities that turn guidelines into action, influencing clinical decision making and behaviour. ${ }^{8,9}$ The dissemination and implementation process consists of specific phases. For this study, Rogers' model of the innovation-decision process was used to guide the process. ${ }^{10}$ The model comprises five stages through which an individual moves across the innovation process. The first step is the knowledge stage in which one hears and reads about the innovation, in this case the pressure ulcer guidelines. The second step is persuasion, in which one adopts a positive or negative attitude towards the guidelines that can be influenced by the characteristics of the guidelines, e.g. if the guidelines are compatible or complex. In the decision stage, one carries out a trial of the innovation, and in the fourth stage, the implementation, the guidelines are actually put into practice. In the final stage, the confirmation stage, the individual looks for support for the decision to use the guidelines, which can be reversed if the individual is exposed to barriers to its use. ${ }^{10}$ Since the introduction of national pressure ulcer prevention and treatment guidelines in the Netherlands in 1985 and 1986 and their revisions in 1992 and $2002^{11-13}$, several studies investigated the adherence to these national pressure ulcer guidelines and revealed that they were often not implemented in daily practice. ${ }^{14-18}$ The reasons for this lack of pressure ulcer guideline implementation are not known. Therefore, the aim of this study is to investigate the current situation regarding pressure ulcer guideline dissemination and implementation in Dutch nursing homes. 


\section{METHODS}

\section{Procedure}

Semi-structured tape-recorded interviews were conducted in eight nursing homes in the Netherlands. The nursing homes were selected via the 2007 database of the Dutch national prevalence measurement of care problems (LPZ). ${ }^{5}$ This database contains pressure ulcer prevalence rates of $53 \%$ of the Dutch nursing homes. A convenience sample of five nursing homes with the lowest pressure ulcer prevalence rates ( $3 \%$ or lower) and five homes with the highest prevalence rates (15\% and higher) was selected, to maximize given answers. The LPZ contact persons in these nursing homes were asked for participation. Eight nursing homes confirmed their participation and two nursing homes declined. When permission was given to participate in the study, the contact person approached eight interviewees within the nursing home. Informed consent was given by all interviewees and permission was given to tape record the interview. The interviews took place within the nursing home in an available room and lasted half an hour to an hour. All interviewees were interviewed separately.

\section{Sample description}

In each nursing home, interviews were held with eight persons: a nurse, two nursing assistants, a tissue viability nurse (if present) or otherwise a member of the pressure ulcer committee, a member of the medical staff, two unit managers and a member of the management team. These persons were chosen because they give a good representation of the staff working in Dutch nursing homes and to obtain information from both caregivers and management. In total 64 interviews were conducted from June 2008 till March 2009.

\section{Interviews}

The interview questions are based on items found in the literature concerning guideline development, dissemination and implementation (published between 1997 and 2006), the Dutch 2002 pressure ulcer guideline and the report of the 2006 annual national pressure ulcer prevalence survey. ${ }^{13-15,19-22}$ Rogers' model of the innovation-decision process was used as a framework for the interviews. ${ }^{10}$ For the knowledge stage the interviewees were asked questions about their awareness of pressure ulcer guidelines, if they had read these guidelines and how they were disseminated within the nursing home. For the persuasion stage, questions were asked about the attitudes of the interviewees towards the guidelines, e.g. if the content of the guidelines confirmed their views about adequate pressure ulcer prevention and treatment. For the decision stage, questions were asked about the presence of the guidelines in practice, if they applied the content of the guidelines in daily practice and if the guidelines were up to date. For the implementation stage, questions were asked about the actual application of guideline recommendations in 
daily practice, such as pressure ulcer risk assessment and repositioning. For the confirmation stage, in which the individual seeks reinforcement for the decision already made, questions were asked about perceived barriers in providing adequate pressure ulcer prevention and treatment in daily practice. In addition to these questions, the interviewees were asked which actions were taken to ease the dissemination and implementation of the pressure ulcer guidelines within the nursing home, such as if a pressure ulcer committee was appointed within the nursing home and if there was a tissue viability nurse working in the nursing home.

\section{Data analysis}

After transcribing the interviews literally, the transcriptions were sent back to the interviewees to check for content validity. The text of the interviews were then analysed by means of manifest and latent content analyses. ${ }^{23}$ The computer program NVivo version 8 was used to organize the data. ${ }^{24}$ The text was read several times by the first author in order to grasp the content as a whole. The analysis continued with the first author selecting meaning units from the text. Codes for each meaning unit were formulated. The codes were sorted into a structure of subcategories and categories by the first author, who identified patterns of similarities and differences, after which an overall theme emerged. This structure was again sorted, grouped and abstracted. The second and fourth author contributed to the analysis by reading, reviewing and discussing these data.

\section{Measures}

In addition to questions about the actual dissemination and implementation of the pressure ulcer guidelines, the interviewees were asked questions about the pressure ulcer policy within the home, namely the presence of wound rounds, the existence of a pressure ulcer committee, the presence of a tissue viability nurse and providing pressure ulcer education for the nursing staff. These actions scored positive (+) if the nursing home had taken such actions and negative (-) if they had not. A description of the criteria used to judge whether these actions were taken will follow. The existence of wound rounds is scored positive if a wound round is held on each ward once a week and if these rounds were attended by at least a nursing home physician and a nursing assistant. The existence of a pressure ulcer committee is scored positive if a multidisciplinary team gathers on a regular basis, at least four times a year, to update the pressure ulcer guidelines present within the nursing home, to monitor their implementation and to implement changes regarding the pressure ulcer care policy within the nursing home. The presence of a tissue viability nurse is scored positive if he/she works within the nursing home or if he/she visits the nursing home on a regular basis. Furthermore, nursing staff should have the possibility to contact the tissue viability nurse for questions. Pressure ulcer education is scored positive if it is a structural education, e.g. if the education is given once a year or once every half a year, that is offered to the nurses and nursing assistants working on the nursing home wards. 


\section{RESULTS}

\section{Description of nursing homes}

An overview of the general characteristics of the eight nursing homes can be seen in Table 3.1. Some nursing homes housed either somatic or psycho geriatric residents, while others housed both.

Table 3.1 General characteristics of the nursing homes.

\begin{tabular}{|c|c|c|c|c|c|c|c|c|}
\hline & $\begin{array}{l}\text { Nursing } \\
\text { home } 1 \\
\text { (low \%) }\end{array}$ & $\begin{array}{l}\text { Nursing } \\
\text { home } 2 \\
\text { (low \%) }\end{array}$ & $\begin{array}{l}\text { Nursing } \\
\text { home } 3 \\
\text { (high \%) }\end{array}$ & $\begin{array}{l}\text { Nursing } \\
\text { home } 4 \\
\text { (high \%) }\end{array}$ & $\begin{array}{l}\text { Nursing } \\
\text { home } 5 \\
\text { (high \%) }\end{array}$ & $\begin{array}{l}\text { Nursing } \\
\text { home } 6 \\
\text { (high \%) }\end{array}$ & $\begin{array}{l}\text { Nursing } \\
\text { home } 7 \\
\text { (low \%) }\end{array}$ & $\begin{array}{l}\text { Nursing } \\
\text { home } 8 \\
\text { (high \%) }\end{array}$ \\
\hline $\begin{array}{l}\text { Prevalence } \\
\text { including } \\
\text { grade } 1\end{array}$ & $4 \%$ & $4 \%$ & $23 \%$ & $33 \%$ & $17 \%$ & $31 \%$ & $14 \%$ & $30 \%$ \\
\hline $\begin{array}{l}\text { Prevalence } \\
\text { excluding } \\
\text { grade } 1\end{array}$ & $2 \%$ & $3 \%$ & $20 \%$ & $15 \%$ & $16 \%$ & $17 \%$ & $3 \%$ & $15 \%$ \\
\hline $\begin{array}{l}\text { Size nursing } \\
\text { home }\end{array}$ & 180 & 103 & 203 & 290 & 189 & 151 & 124 & 190 \\
\hline Residents & $\begin{array}{l}\text { Psycho } \\
\text { geriatric }\end{array}$ & $\begin{array}{l}\text { Psycho } \\
\text { geriatric }\end{array}$ & Somatic & $\begin{array}{c}\text { Somatic } \\
\text { and } \\
\text { psycho } \\
\text { geriatric }\end{array}$ & Somatic & $\begin{array}{c}\text { Somatic and } \\
\text { psycho } \\
\text { geriatric }\end{array}$ & Somatic & $\begin{array}{c}\text { Somatic and } \\
\text { psycho } \\
\text { geriatric }\end{array}$ \\
\hline $\begin{array}{l}\text { Specialised } \\
\text { wards }\end{array}$ & & & $\begin{array}{c}\text { Palliative } \\
\text { care }\end{array}$ & $\begin{array}{c}\text { Palliative } \\
\text { care }\end{array}$ & & Rehabilitation & Rehabilitation & Rehabilitation \\
\hline
\end{tabular}

\section{Knowledge stage}

All eight nursing homes had institutional pressure ulcer prevention and treatment guidelines within their nursing home and on the nursing home wards. Often the prevention and treatment guidelines were combined into one document. All interviewees were aware of the existence of pressure ulcer guidelines in their nursing home and on their wards. Furthermore, all interviewees stated that they had read the guidelines. The pressure ulcer guidelines were all based on Dutch national guidelines, either the CBO guideline or the Salode guideline (a Dutch guideline for organising multidisciplinary pressure ulcer care in nursing homes). ${ }^{13,25}$ Adaptation of the national pressure ulcer guidelines to the institutional situation was carried out in all eight nursing homes by a multidisciplinary team. The composition of these teams differed for each home. The following disciplines were identified: nurses, nursing assistants, a tissue viability nurse, a nursing home physician, a physiotherapist and/or an occupational therapist. Answers given to the question of which strategies were used to disseminate the pressure ulcer guidelines within the nursing home varied from putting the guidelines on the intranet, to discussing the guidelines within team discussions on the wards. Some nursing homes used a multifaceted dissemination strategy, while others only distributed a text document of the guidelines to the wards. An overview of the development and dissemination processes in the nursing homes can be seen in Table 3.2. 


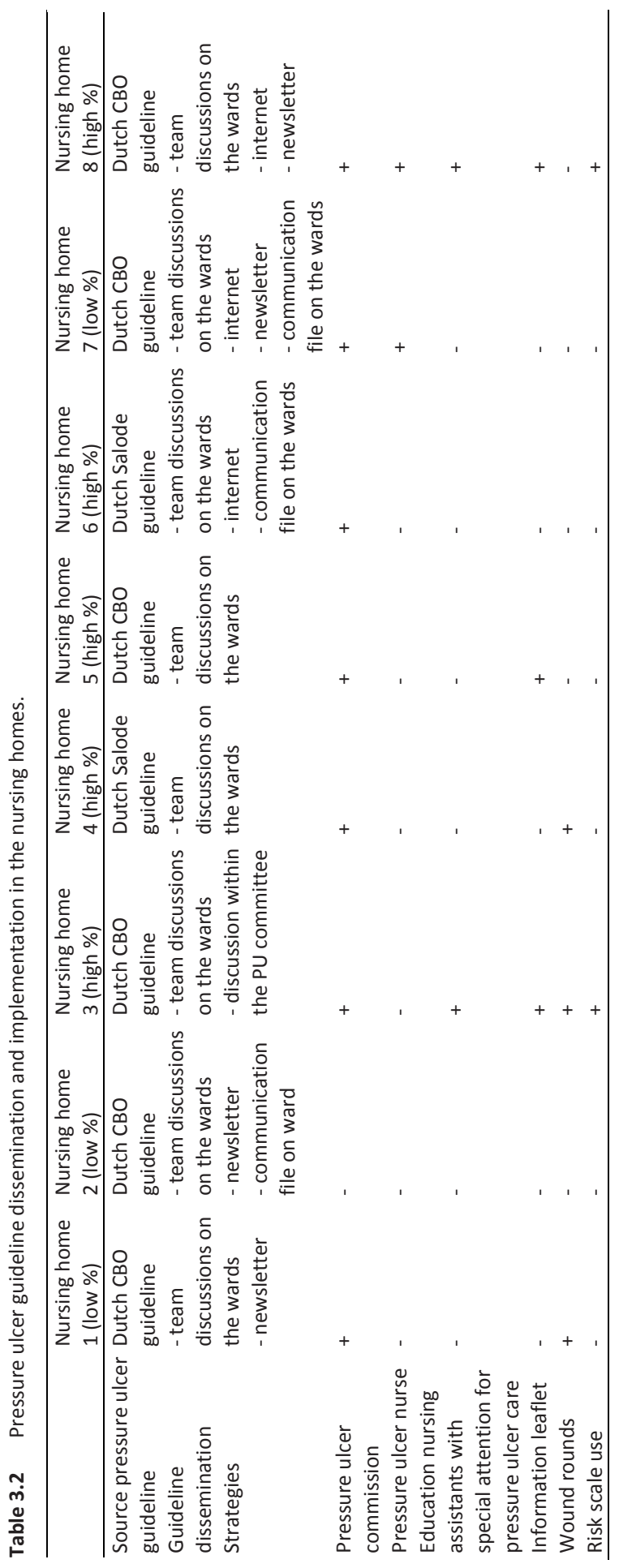




\section{Persuasion stage}

All interviewees stated that the pressure ulcer guidelines used within their nursing home mostly confirmed their views about adequate and efficient pressure ulcer prevention and treatment, indicating that all interviewees had a positive attitude towards the pressure ulcer guidelines used within their nursing home.

\section{Decision stage}

All interviewees said they applied the content of the guidelines in daily practice. However, the pressure ulcer prevention and treatment guidelines were not updated on a regular basis in all nursing homes. In some homes there was a system of updating the guidelines on a regular basis, e.g. once a year, while in most of the homes no date for updating the guidelines was set.

\section{Implementation stage}

In order to investigate the actual implementation of the institutional pressure ulcer guidelines, the interviewees were asked questions about the application of some guideline recommendations in daily practice, namely: performing pressure ulcer risk assessment, repositioning residents and the education of residents with the aim of preventing pressure ulcers.

\section{Pressure ulcer risk assessment}

The interviews revealed that seven out of the eight nursing homes had a pressure ulcer risk assessment scale within their nursing home. The Braden scale was the most often mentioned risk assessment scale. In six nursing homes the risk scale was filled in twice a year for every resident, before the multidisciplinary resident meetings. In some of the nursing homes they also filled in the scale for every new resident. Clinical judgement was used in the nursing home where no pressure ulcer risk assessment scale was available. Although most of the nursing homes reported to have a pressure ulcer risk assessment scale, often, according to the answers given by the interviewees, this scale was not used in practice. Unit manager: 'It is written very clearly in the guidelines that you have to judge the risk of developing a pressure ulcer for every new resident and when someone has a decline in their state of health, but we do not judge residents according to a pressure ulcer risk assessment scale'. In the nursing home where no pressure ulcer risk assessment scale was used, the interviewees mentioned that they found it difficult to judge if a resident had a high risk of developing a pressure ulcer.

\section{Repositioning}

During the interviews the interviewees were asked questions about repositioning residents when the residents had limited mobility or activity levels. The interviewees were asked if they used a repositioning scheme within the home and if these schemes were 
adhered to. In three of the nursing homes, they had a repositioning scheme in the residents' file or near the bedside of the resident which they had to fill in after repositioning the resident. The interviews revealed that these schemes were often not filled in. Reasons for this were lack of time and forgetting to fill in the scheme. Unit manager: 'Experience has shown that, if residents have a repositioning scheme, they are not filled in. The discussion is then of course about whether they forgot to fill it in or if they have not repositioned the resident at all...anyhow, these schemes are filled in very badly or not at all'. Some interviewees mentioned that although their colleagues indicated on the scheme that they had repositioned the resident, they perceived that in fact this had not been performed. Nursing assistant: 'With repositioning we see that people cheat with that. They say they have repositioned the resident and fill in the scheme, but if you come back you see that the resident is still lying in the same position'. Moreover, some interviewees mentioned that their colleagues believed that repositioning was not necessary when a resident was already lying on a pressure relieving mattress. Nurse: 'A lot of colleagues think that if a resident has a pressure relieving mattress they don't have to reposition the resident; that is of course not the case, but this is the idea that a lot of colleagues have'. Furthermore, in some of the cases, repositioning was not performed at all because the resident did not want it.

\section{Educating residents}

Informing the residents and their relatives about the risk for developing pressure ulcers and what they could do to avoid it, was performed in three nursing homes by means of a special information leaflet about pressure ulcer care. This leaflet was given to the residents and their relatives during the interview on admission to the nursing home. Furthermore, some interviewees revealed that besides written information oral information was also given to the residents and their relatives.

\section{Confirmation stage}

The implementation of the pressure ulcer guidelines has to be evaluated in order to investigate the effectiveness of the implementation. In this study, evaluation took place by asking the interviewees if they were exposed to barriers in applying guideline recommendations in daily practice. The most often mentioned barriers were related to personnel. First of all, a lack of (qualified) personnel and lack of nurses/nursing assistants' knowledge/education were mentioned as a barrier. Nurse: 'In this nursing home we work with a lot of helping aids, these are people that start to work here without any education in the area of nursing. These people rely on the information they get from the persons that have to settle them into the job. I think that these persons need a lot more education'. The resistance of residents was also brought up as a barrier. Unit manager: 'One resident arrived in this nursing home without a pressure ulcer. This woman wanted to stay in bed; she didn't want to get out...now she has developed a pressure ulcer'. Furthermore, a lack of motivation by colleagues was stated as a barrier in giving adequate pressure ulcer care. 
Besides a lack of motivation, the stubbornness of nurses and nursing assistants was pointed to as a barrier. Unit manager: 'Well, you have people who go their own way... they don't listen to suggestions or advice from others, that is of course not the intention, but that is what happens sometimes in daily practice'. Moreover, non-compliance with appointments was brought up as a barrier to providing adequate pressure ulcer care. For example, forgetting to give extra nutritional support when needed, changing incontinence material when needed and lifting residents in wheelchairs who cannot move themselves. Nurse: 'What I have noticed lately is that with residents who get nutritional support, colleagues forget to give it to them. It stays in the refrigerator, or sometimes they throw it away if it is expired, that sort of things'. Another frequently stated barrier was lack of attention to pressure ulcer care by colleagues. Nurse assistant: 'Not everybody has the same level of attention to pressure ulcer care and if you have no attention to it, or less attention, then you develop of course less know-how'. Finally, bad communication between the different disciplines was mentioned by some of the interviewees as a barrier.

\section{Pressure ulcer policy}

In addition to questions about the dissemination and implementation of the pressure ulcer guidelines, the interviewees were also asked which actions were taken to ease the dissemination and implementation of the pressure ulcer guidelines within the nursing home. The answers to these questions are summarized in Table 2 and will be described in the following categories: the presence of a pressure ulcer committee, a tissue viability nurse, persons with special attention for pressure ulcer care on the wards, wound rounds and pressure ulcer education.

\section{Pressure ulcer committee}

In seven out of the eight nursing homes there existed a committee responsible for organising pressure ulcer care in the nursing home. The tasks of these committees were to disseminate and implement the pressure ulcer guidelines within the nursing home. The composition of these committees, whether mono- or multidisciplinary, varied between the homes.

\section{Tissue viability nurse}

Two of the eight nursing homes had a tissue viability nurse working in the nursing home. The tasks of this nurse are to answer questions from ward personnel regarding pressure ulcer prevention and/or treatment, to disseminate and implement changes in pressure ulcer prevention and/or treatment material within the nursing home and to update ward personnel when there are changes in the pressure ulcer policy within the nursing home. This occurs in the nursing homes by means of a presentation during the regular team meetings or by putting the information in the nursing home newsletter. 


\section{Nurses/nursing assistants with special attention for pressure ulcer care}

In all the nursing homes there was a nurse or nursing assistant on every ward for whom pressure ulcer care is an area of special attention. This person is the contact person for the personnel on the ward when there are questions regarding pressure ulcer care. In most of the nursing homes these nurses/nursing assistants were also members of the nursing home pressure ulcer committee. They are also responsible for updating the rest of the ward personnel when there are changes in pressure ulcer prevention or treatment, e.g. if there are different wound treatment materials. Most of the time, the ward meetings were used to disseminate this information to the rest of the ward personnel. These nurses/nursing assistants did not always have a special education in wound/pressure ulcer care; only in a couple of the nursing homes these persons had done a course with some additional pressure ulcer education.

\section{Wound rounds}

In three of the eight nursing homes they held wound rounds on the wards. During these wound rounds the nursing home physician and a nurse or nursing assistant visited all residents with a pressure ulcer to investigate the wound and to discuss wound prevention and/or treatment. These wound rounds were held once a week, mostly on one specific day on each ward. In one of the nursing homes where wound rounds were held, the interviewees mentioned that these rounds were not effective. This ineffectiveness was caused by the fact that the responsibilities of the different professionals during and after these rounds were unclear. Nurse: Within this nursing home we hold wound rounds on every ward, but the interpretation of these rounds is very unclear. It has been shown in the past that these rounds don't have so much effect. The different disciplines discuss the residents' situation, but they don't have a plan about who is going to do what'.

\section{Registration of pressure ulcers}

In only two of the nursing homes was there a central registration of residents with a pressure ulcer. The registration in these homes was the responsibility of the nursing home physician or the staff nurse.

\section{Pressure ulcer education}

Education for nursing staff about pressure ulcer prevention and treatment was given in most of the nursing homes. In most cases, the education offered was internal, but in some cases it was external. Because of financial issues, the possibility for external education was limited. Clinical lessons, workshops and congresses were mentioned as forms in which the education was provided within or outside the nursing homes. In none of the homes was there an obligation for the nursing staff to follow a specific amount of education. Nursing staff were free to choose their subjects/themes of interest, which may or may not have included pressure ulcer or wound care. Consequently, not all nursing staff had a specific 
number of hours of education in this area during the past years. In some homes, the nurses and nursing assistants answered that they perceived that not enough internal and/or external education was given in the area of pressure ulcer care. In none of the homes was there any control over the amount of pressure ulcer care education followed by the nursing staff. Nursing assistant: 'Yes, I think that education should be offered more frequently. Persons should also be obliged to follow education, since some people always sign up for education, while most don't'. Some of the interviewees answered that the knowledge of nursing staff regarding pressure ulcer care was lacking and that more education in this field was needed. Member of medical staff: 'The general level of knowledge about pressure ulcer care is just too low, and the problem is always that you have a lot of nursing trainees and if there are no nurses but mainly nursing assistants, their knowledge level is just not that high'. In one of the nursing homes there was a system for providing pressure ulcer care education two times a year and it was obligatory for nursing trainees and new personnel to participate in this education. Nevertheless, in the past year no pressure ulcer education was given. The reasons for this were other priorities and forgetting to organise new education.

\section{DISCUSSION}

The goal of this study was to investigate the current situation regarding pressure ulcer guideline dissemination and implementation in Dutch nursing homes. The results show that pressure ulcer prevention and treatment guidelines, based on Dutch national guidelines, are present in all eight nursing homes, but these guidelines were not updated in all nursing homes on a regular basis. Since the CBO guideline was last updated in 2001, the guidelines in some of the nursing homes have not been updated since then. ${ }^{13}$ This may result in outdated prevention and treatment or unknown new prevention and treatment recommendations. To avoid this, it is important to update guidelines on a regular basis. Previous studies recommend that guidelines should be reassessed for validity and updated every three to 5 years. ${ }^{20,26,27}$ The dissemination of the pressure ulcer guidelines within the nursing homes seems to be successful in all the nursing homes, as all the interviewees knew about the existence of the pressure ulcer guidelines and where to find them, and said they had read them. When looking at the applied strategies used to disseminate the pressure ulcer guidelines within the nursing home, one can see that most of these strategies are passive. Research has shown that passive strategies, such as simply providing educational materials, whether in written form or by mail, have little to no effect in changing practices. ${ }^{8,20,28,29}$ Furthermore, six nursing homes used a multifaceted dissemination strategy, which has been recognised as a successful dissemination approach by some studies, ${ }^{8,28}$ while others found it not necessarily more effective than single interventions. $^{30}$ Unlike the dissemination of the pressure ulcer guidelines, the implementation of the guidelines did not seem to be successful in all nursing homes. Although all interviewees answered that they applied the content of the guidelines in daily 
practice, the answers given to questions about specific guideline recommendations did not confirm this. For example, initial risk assessment. Although interviewees in seven nursing homes reported to have a pressure ulcer risk assessment scale, these scales were only effectively used in practice in two nursing homes. Moreover, not all the interviewees knew if a risk assessment scale was present within their nursing home and some mentioned that they did not perform risk assessment for new residents. In some nursing homes the interviewees mentioned that they found it difficult to judge if a resident had a high risk of developing a pressure ulcer. This indicates a lack of knowledge about risk assessment and a lack of implementation of this specific guideline recommendation. Another poorly implemented guideline recommendation is repositioning. The interviews revealed that only three nursing homes actually had a repositioning scheme for the residents. However, these schemes were often not used and/or filled in. Here, too, a lack of knowledge was identified, since some interviewees believed that repositioning is not necessary when a resident already has a pressure relieving mattress. This lack of knowledge about pressure ulcer care by nursing home staff is confirmed by previous research. ${ }^{14-18}$ Furthermore, some of the interviewees mentioned that they perceived that not enough pressure ulcer education was offered. Moreover, when pressure ulcer education was offered in the nursing homes, following this education was not obligatory in any of the nursing homes. In addition, there was no way of ascertaining whether persons had followed pressure ulcer education in past years or not in any of the nursing homes. This indicates the possibility that nursing staff have not followed any pressure ulcer education at all. Therefore, the knowledge level of the nursing staff in nursing homes remains unknown and it is questionable if the knowledge level of nursing home staff is adequate and up to date. This was confirmed by the fact that some of the interviewees confirmed a lack of knowledge about pressure ulcer prevention, for example by answering that repositioning is not necessary when a resident is already lying on a pressure relieving mattress. Furthermore, when asking the interviewees about barriers to providing adequate pressure ulcer care, a lack of knowledge among their colleagues was frequently mentioned. Considering the amount and non-committal nature of pressure ulcer education on offer, this is partly explainable. Altogether, this indicates that pressure ulcer education needs more attention in nursing homes in order to increase the knowledge of the nursing home staff and to keep their knowledge up to date. Other frequently mentioned barriers to providing adequate pressure ulcer care were the lack of motivation and stubbornness of colleagues, non-compliance with appointments by colleagues and inadequate communication between disciplines. Insight into the barriers to implementing pressure ulcer guideline recommendations is essential in order to develop strategies that can be used to increase adequate pressure ulcer care in daily practice. When investigating the actions taken to facilitate the dissemination and implementation of pressure ulcer guidelines, one can see that all eight nursing homes appointed nursing assistants with special attention for pressure ulcer care on every ward. The idea behind appointing these persons was that these persons have a consulting function for the other staff on their ward. However, education for these nursing assistants was only offered in two of the 
nursing homes. Therefore, one can judge the effectiveness of appointing these persons in improving the quality of pressure ulcer care on the wards, while up to date knowledge seems to be essential in assisting colleagues with questions. Another action taken to facilitate the dissemination and implementation of pressure ulcer guidelines was the introduction of wound rounds, but these were only organised in three of the nursing homes. Furthermore, in one of these three homes the wound rounds were not effective. Efficient wound rounds can lead to increased attention to pressure ulcer care on the wards resulting in an increase in the quality of pressure ulcer care, as previous studies have shown that more attention for pressure ulcer care can result in decreased pressure ulcer prevalence rates. ${ }^{31}$ One can conclude that the implementation of pressure ulcer guidelines in Dutch nursing homes needs more attention. Offering sufficient and obligatory education for nursing home staff and increasing the attention given to pressure ulcer care in the nursing homes, e.g. by means of organising efficient wound rounds on the wards, can be the first steps in initiating an increase in the degree of pressure ulcer guideline implementation in Dutch nursing homes.

\section{Limitations}

It is important to notice that because the interviews were held in eight nursing homes throughout the Netherlands, it could be possible that the results present a skewed view of the current state of pressure ulcer guideline implementation in Dutch nursing homes. 


\section{REFERENCES}

1. De Laat EHEW, Scholte op Reimer WJ, Van Achterberg T. Pressure ulcers: diagnostics and interventions aimed at wound-related complaints: a review of the literature. Journal of Clinical Nursing 2005;14:464-472.

2. Allman RM. Pressure ulcer prevalence, incidence, risk factors, and impact. Clinics in Geriatric Medicine 1997;13:421-436.

3. Bours GJJW, Halfens RJG, Lubbers M, Haalboom JRE. The development of a national registration form to measure the prevalence of pressure ulcers in the Netherlands. Ostomy Wound Management 1999;45:28-40.

4. Bours GJJW, Halfens RJG, Wansink SW. Landelijk prevalentie onderzoek decubitus: resultaten zesde jaarlijkse meting 2003. Maastricht: Universiteit Maastricht; 2003.

5. Halfens RJG, Meijers JMM, Neyens JCL, Offermans MPW. Rapportage resultaten: Landelijke Prevalentiemeting Zorgproblemen 2007. Maastricht: Maastricht University; 2007.

6. Halfens RJG, Meijers JMM, Neyens JCL, Offermans MPW. Rapportage resultaten: Landelijke Prevalentiemeting Zorgproblemen 2008. Maastricht: Maastricht University; 2008.

7. Donabedian A. Institutional and professional responsibilities in quality assurance. Quality Assurance in Health Care 1989;1:3-11.

8. Davis DA, Taylor-Vaisey A. Translating guidelines into practice: a systematic review of theoretic concepts, practical experience and research evidence in the adoption of clinical practice guidelines. Canadian Medical Association Journal 1997;157:408-416.

9. Cheater FM, Closs SJ. The effectiveness of methods of dissemination and implementation of clinical guidelines for nursing practice: a selective review. Clinical Effectiveness in Nursing 1997;1:4-15.

10. Rogers EM. Diffusion of innovations, 5th edition. New York: The Free Press; 2003.

11. Centraal Begeleidingsorgaan voor de Intercollegiale Toetsing. Consensus preventie van decubitus. Utrecht: Centraal Begeleidingsorgaan voor de Intercollegiale Toetsing; 1985.

12. Centraal Begeleidingsorgaan voor de Intercollegiale Toetsing. Herziening consensus decubitus. Utrecht: Centraal Begeleidingsorgaan voor de Intercollegiale Toetsing; 1992.

13. Centraal Begeleidingsorgaan voor de Intercollegiale Toetsing. Decubitus. Tweede herziening. Alphen aan den Rijn: Van Zuiden; 2002.

14. Inspectie voor de Gezondheidszorg. Decubitus doorgelicht: richtlijn onvoldoende in praktijk toegepast: een onderzoek naar de kwaliteit van de decubituszorg in Nederland en maatregelen om het aantal patiënten met decubitus te verminderen. Den Haag: Inspectie voor de Gezondheidszorg; 2004.

15. Bours GJJW, Halfens RJG, Huijer Abu-Saad H, Grol RTPM. Prevalence, prevention and treatment of pressure ulcers: descriptive study in 89 institutions in the Netherlands. Research in Nursing \& Health 2002;25:99-110.

16. Buss IC, Halfens RJG, Huijer Abu-Saad H, Kok G. Pressure ulcer prevention in nursing homes: views and beliefs of enrolled nurses and other health care workers. Journal of Clinical Nursing 2004;13:668-676.

17. Halfens RJG, Eggink M. Knowledge, beliefs and use of nursing methods in preventing pressure sores in Dutch hospitals. International Journal of Nursing Studies 1995;32:16-26.

18. Hulsenboom MA, Bours GJ, Halfens RJ. Knowledge of pressure ulcer prevention: a crosssectional and comparative study among nurses. BMC Nursing 2007;6.

19. Halfens RJG, Janssen MAP, Meijers JMM. Rapportage resultaten: Landelijke Prevalentiemeting Zorgproblemen 2006. Maastricht: Maastricht University; 2006. 
20. National Health and Medical Research Council. A guide to the development, implementation and evaluation of clinical practice guidelines. Canberra: National Health and Medical Research Council; 1999.

21. Cluzeau F, Littlejohns P, Grimshaw J, Feder G. Appraisal instrument for clinical guidelines, version 1. London: St. George's Hospital Medical School; 1997.

22. The AGREE Collaboration. Appraisal of Guidelines for Research \& Evaluation (AGREE) instrument. www.agreecollaboration.org; 2001.

23. Berg B. Qualitative research methods for the social sciences, 5th edition. Boston MA: Pearsons Education Inc; 2004.

24. QSR International Pty Ltd. Qualitative data analysis software, version 8 [computer program]; 2008.

25. Nederlandse Vereniging van Verpleeghuisartsen. Tripartiete multidisciplinaire richtlijn: samenwerking en logistiek rond decubitus. Utrecht: Nederlandse Vereniging van Verpleeghuisartsen; 2003.

26. Shekelle PG, Ortiz E, Rhodes S, Eccles M, Grimshaw J, Woolf SH. Validity of the Agency for Healthcare Research and quality clinical practice guidelines: how quickly do guidelines become outdated? Journal of the American Medical Association 2001;286:1461-1467.

27. Grol R, Wensing M. Implementatie: Effectieve verandering in de patiëntenzorg. Maarssen: Elsevier gezondheidszorg; 2001.

28. Oxman AD, Thomson MA, Davis DA, Haynes B. No magic bullets: a systematic review of 102 trials of interventions to improve professional practice. Canadian Medical Association Journal 1995;153:1423-1431.

29. Feder G, Eccles M, Grol R, Griffiths C, Grimshaw J. Using clinical guidelines. British Medical Journal 1999;318:728-730.

30. Grimshaw JM, Thomas RE, MacLennan G, Fraser C, Ramsay CR, Vale L, Whitty P, Eccles MP Matowe L, Shirran L, Wensing M, Dijkstra R, Donaldson C. Effectiveness and efficiency of guideline dissemination and implementation strategies. Health Technology Assessment 2004;8:341-352.

31. Meijers JM, Candel MJ, Schols JM, van Bokhorst-de van der Schueren MA, Halfens RJ. Decreasing trends in malnutrition prevalence rates explained by regular audits and feedback. Journal of Nutrition 2009;139:1381-1386 


\section{CHAPTER 4}

THE IMPLEMENTATION OF PRESSURE ULCER GUIDELINES IN DUTCH AND GERMAN NURSING HOMES: A QUALITATIVE STUDY 


\section{ABSTRACT}

Background. Although national pressure ulcer guidelines seem to have been disseminated successfully to nursing homes in the Netherlands and Germany, for unknown reasons they have not always been implemented in either country.

Objectives. This study aims to compare the process of pressure ulcer guideline dissemination and implementation in nursing homes in the Netherlands and Germany.

Method. A qualitative study conducted in eight nursing homes in the Netherlands and ten German nursing homes. In total 94 semi-structured interviews were conducted with nursing staff representatives within the nursing homes. Qualitative analysis of the interview transcripts was conducted.

Results. All nursing homes in both countries had institutional pressure ulcer prevention and treatment guidelines. Strategies used to disseminate the guidelines differed among nursing homes and between countries. Implementation obstacles were mostly related to personnel and lack of motivation. Insufficient knowledge concerning guideline recommendations was observed during the interviews. Pressure ulcer education was offered in both countries in most nursing homes. Nevertheless, attendance was not obligatory in the Dutch nursing homes.

Discussion. The implementation of pressure ulcer guidelines in Dutch and German nursing homes deserves more attention. Obstacles in the implementation of pressure ulcer guidelines should be addressed. Areas for improvement include enhancing the level of nursing staffs' knowledge with regard to pressure ulcer care and increasing awareness for pressure ulcer care. Further research should focus on obstacles to implementing guideline recommendations in daily practice and the gaps in nurses' knowledge with regard to pressure ulcer prevention and treatment in nursing homes. 


\section{INTRODUCTION}

Pressure ulcers are still a common and serious health care problem in nursing homes with prevalence rates varying from $7.7 \%$ to $83.6 \% .{ }^{1-3}$ Pressure ulcers can result in a decreased quality of life, increased morbidity and mortality rates, an increased need for intensive nursing and medical care, an increased workload for healthcare workers and, as a consequence, increased healthcare costs. ${ }^{4-6}$

Results from annual national pressure ulcer point prevalence surveys in the Netherlands and Germany, using the same standardized definitions, instruments and methodology ${ }^{7}$, reveal large differences in prevalence rates between both countries over the past ten years, especially in nursing homes. ${ }^{8,9}$ Rates in Dutch nursing homes (30.8\%) are reported to be over three times as high compared to those in German nursing homes (8.3\%). ${ }^{9}$

Clinical guidelines for the prevention of pressure ulcers have been developed nationally and internationally over the past years. ${ }^{10-12}$ The use of guidelines is generally assumed to have several benefits, such as improvement of the quality, consistency and efficiency of patient care. ${ }^{13,14}$ To change clinical practice, guidelines must be disseminated and implemented in clinical practice. Regretfully, numerous examples from daily nursing practice show how the implementation of guidelines is often not accomplished. ${ }^{15-20}$ Several studies have shown that at least $30-40 \%$ of patients do not receive care according to current scientific evidence, while $20 \%$ or more of the care provided is not needed or is potentially harmful. $^{21,22}$

Previous research has shown that the dissemination of the national pressure ulcer guidelines to the nursing homes was successful in the Netherlands and Germany. ${ }^{23-25}$ The implementation of pressure ulcer guidelines in Dutch nursing homes has been investigated in several studies. All these studies show that the Dutch national guidelines were not (completely) followed in daily pressure ulcer care. ${ }^{26-28}$ A recent study performed in German nursing homes revealed that pressure ulcer prevention measures, though not recommended any more, were still being used. ${ }^{29}$ The exact reason for this lack of guideline implementation in both countries is unknown. Therefore, this study aimed to investigate and compare the process of pressure ulcer guideline dissemination and implementation in nursing homes in the Netherlands and Germany by using a qualitative approach in order to reveal which aspects may influence the differences in pressure ulcer prevalence rates between both countries.

\section{METHOD}

\section{Procedure}

For this study, a qualitative approach was followed, using interviews with nursing staff representatives in both countries. In eight nursing homes in the Netherlands and ten nursing homes in Germany semi-structured tape-recorded interviews were performed. 
The Dutch nursing homes were selected from the list of participants in the annual national point prevalence measurement of care problems (Landelijke Prevalentiemeting Zorgproblemen, LPZ) in $2007^{30}$ and the German point prevalence survey in $2007 .{ }^{31}$ In the Netherlands, $53 \%$ of the Dutch nursing homes provide data to the LPZ; the German database contains prevalence rates for nursing homes in and around Berlin and Brandenburg. To maximize heterogeneity in both countries, a convenience sample of five nursing homes with a low pressure ulcer prevalence rate (3\% or lower) and five homes with a high prevalence rate (15\% and higher) was selected. In the Dutch nursing homes, the LPZ institutional contact persons were invited to participate. Eight nursing homes confirmed their participation and two nursing homes declined, due to lack of time. In Germany all nursing home managers confirmed the participation of their nursing home. When permission was given by the nursing home management to participate in the study the contact person selected the interviewees in their nursing home. All interviewees gave their informed consent and permission to record the interview, which lasted 30-60 minutes. All participants were interviewed individually, in the Netherlands by the first author (EM) and in Germany by two master's degree students.

\section{Participants}

In each Dutch nursing home, interviews were held with eight persons: a nurse, two nursing assistants, a tissue viability nurse (if present, otherwise a member of the pressure ulcer committee, a multidisciplinary team that monitors pressure ulcer care policy in the nursing home), a member of the medical staff, two unit managers and a member of the management team. These persons were chosen because they represented the range of staff working in Dutch nursing homes, and to obtain information from both caregivers and management. In total 64 interviews were conducted in the Netherlands from June 2008 till March 2009.

The staffing situation in German nursing homes differs from the Dutch situation, since Dutch nursing homes employ an entire multidisciplinary team. Therefore it was chosen to interview three representatives of the nursing staff in each nursing home; a nurse, a head nurse and a staff member of the quality and safety department. In total 30 interviews were conducted in Germany from June till December 2008.

\section{Interview questions}

Semi-structured tape-recorded interviews were held with all the interviewees. The interview was guided by Rogers' model of the innovation-decision process, consisting of 5 stages. ${ }^{32}$ In the first stage, the knowledge stage, one hears and reads about the guideline. In the next stage, the persuasion stage, one adopts a positive or negative attitude towards the guideline. The innovation is tested in the third stage, the decision stage. Subsequently, in the fourth stage, the implementation stage, the guideline is actually put into practice. In the confirmation stage, the final stage, the person decides to use the guideline definitely or not. ${ }^{32}$ The interview questions were based on items found in the implementation 
literature. ${ }^{33-37}$ The interviewees were asked whether their nursing home used a pressure ulcer guideline and, if so, if this was a national guideline or a guideline developed by the home itself. In the latter case it was questioned who had developed this guideline, how the guideline was developed, if it had been tested for practicability in a pilot phase and if it was regularly updated. Questions were also asked about the dissemination and implementation of the pressure ulcer guideline in the nursing home, which strategies were used to disseminate and implement the guideline, which obstacles were met during the dissemination and implementation and which actions were taken to ensure the use of the guidelines on the wards. Finally, questions were asked about the amount and frequency of pressure ulcer education offered by the nursing home.

\section{Analysis}

After literal transcription, the interview texts were sent to the interviewees for comments. After processing these comments the first author (EM) analysed the Dutch interviews and two master students analysed the German interviews by means of manifest content analysis $^{38}$ and used the NVivo version 8 computer program to organize the data. After careful reading of the text several times to grasp the content as whole, meaningful units were selected from the text. For each meaningful unit codes were formulated. These codes were then sorted in a structure of categories and subcategories by the first author to identify patterns of similarities and differences, after which an overall theme emerged. This structure was again sorted, grouped and abstracted. Two study coauthors, who were not involved with the data collection, reviewed the preliminary content analysis against the transcripts.

\section{RESULTS}

Under here the results of this study will be presented according to the five stages of Rogers' model of the innovation-decision process; knowledge, persuasion, decision, implementation and confirmation. ${ }^{32}$

\section{Knowledge stage}

Printed pressure ulcer prevention and treatment guidelines were present on the wards of all Dutch and German nursing homes, often combined in one document.

\section{Awareness}

All Dutch and German interviewees, except for three staff members of the German quality and safety departments, were aware of the existence of pressure ulcer guidelines in their nursing home and knew where to find the guidelines. 


\section{Source guideline}

In the Dutch nursing homes, the pressure ulcer guidelines were all based on available national guidelines. ${ }^{23,39}$ In Germany, eight nursing homes had pressure ulcer guidelines based on the national German Expert Standard ${ }^{24}$ as confirmed by a German head nurse (GER4): 'Our guideline is derived from the Expert Standard'. The guidelines used in the two other nursing homes were based on another guideline, namely the guideline from the European Pressure Ulcer Advisory Panel. ${ }^{11}$ One of these nursing homes was working on adapting their pressure ulcer guidelines to the German Expert Standard.

\section{Development group}

Pressure ulcer committees present in all Dutch nursing homes adapted the national pressure ulcer guidelines to their institutional situation. These committees included representatives of the following disciplines: nurses, nursing assistants, tissue viability nurses, nursing home physicians, physiotherapists and/or occupational therapists. A quality team or pressure ulcer working group of nurses and nursing assistants carried out the adaptation in the German nursing homes. In some German nursing homes, members of the quality and safety department or head nurses were also in these groups. German nursing homes that were part of a larger care foundation had multidisciplinary teams, consisting of representatives from the various care homes, to adapt the pressure ulcer guidelines.

\section{Dissemination strategies}

Strategies used to disseminate the pressure ulcer guidelines in the Dutch nursing homes included discussions in the team's ward meetings and pressure ulcer committee meetings, newsletter items, notes in the wards' communication file and postings on the intranet. In the German nursing homes, the guideline dissemination took place through discussions at team meetings or ward meetings and by distributing the guidelines to all nursing personnel on the wards. Some nursing homes in both countries used a multifaceted dissemination strategy, while others only distributed printed copies of the guideline. The strategies used were sometimes arbitrary. One German nurse (GER10) reported: 'I know they tried several ways of getting the guideline to all of the staff. It took a long time, and at first it was one big mess on all levels, but in the end we got the message'.

\section{Guideline updates}

The pressure ulcer prevention and treatment guidelines were not updated regularly in all Dutch nursing homes. Some homes have a system of regular annual updates but most homes had no date set for updating the guideline. All German nursing homes updated their guideline on a regular basis. In three nursing homes they updated the pressure ulcer guideline yearly; while in the others they carried out two-yearly or less frequent but 
regular updates. Those responsible for updating the guidelines are head nurses or members of the quality and safety department.

\section{Persuasion stage}

All interviewees stated that they had read the guidelines. Nevertheless, their or their colleagues' motivation to read the guideline was sometimes lacking. A German nurse (GER14) says: 'My motivation goes down a bit more every time I have to deal with written material, anything put down written on paper'. A Dutch nursing assistant (NL21) explains: 'Well, off course people read the guideline, but they are very reserved. It is after all a lot of reading material and people don't like that'. All Dutch and German interviewees, except for one German nurse, stated that the pressure ulcer guidelines used in their nursing home were compatible with their own views on well-organized and adequate pressure ulcer care. This indicates that nearly all the interviewees had a positive attitude to the pressure ulcer guidelines used in their nursing home.

\section{Decision stage}

All Dutch interviewees and nearly all German interviewees said that the guidelines were applied in daily practice. However, some German nurses pointed out that the guidelines were not completely suitable to use and therefore not fully applied in daily practice. German nurse (GER10): 'Applying the rules as written just isn't possible. They have nothing to do with the reality of our profession. As they are written now, they cannot be put into practice'.

\section{Pilot guideline}

None of the Dutch nursing homes had organized a pilot phase to test the feasibility and quality of the pressure ulcer guideline. In Germany, six nursing homes had done so, but the remaining four had not. A German nurse (GER18) says: 'When the quality team was developing the guideline, they presented it to us at a meeting. We could say what was missing or needed improvement, but there was no strict testing in our nursing home, we just implemented it straight away'.

\section{Implementation stage}

\section{Educating residents}

Three Dutch nursing homes produced a special information leaflet about pressure ulcer care to inform residents and their relatives about the development of pressure ulcers and what they can do to prevent them. On admission to the nursing home, the leaflet is given to residents and their relatives. None of the German nursing homes had an information leaflet on pressure ulcer care and in one nursing home they actually chose not to give residents and relatives a leaflet to avoid interference by relatives. A German nurse 
(GER14) explains: 'We think it's better not to tell them that our guideline exists, otherwise they'd come up with all kinds of questions and complaints'.

\section{Controlling strategies}

The interviewees were asked how the quality of care and thereby the correct use of guidelines was checked in their nursing home. The Dutch interviewees mentioned a couple of controlling strategies, such as the inspections from the Dutch Health Care Inspectorate. A Dutch nursing assistant (NL34) says: 'Sometimes the health care inspectorate comes and checks, but this is not really directed at daily nursing care, more the management level'. Other strategies to check whether adequate pressure ulcer care was being provided were weekly pressure ulcer wound rounds held in some nursing homes as well as the Dutch annual point prevalence measurement of care problems. ${ }^{7}$ The German interviewees mentioned the following strategies: regular internal checks on how well nursing staff was functioning, carried out during the daily care of the residents, occasional inspections by the nursing home's board of directors, and occasional external quality management inspections by the MDK (the medical services of statutory health insurance bodies in Germany) respectively. Most interviewees regarded the MDK inspections as positive. The chance of being given a negative function appraisal worked to motivate nurses to provide adequate care. A German nurse (GER24) confirms this: 'You could say that the MDK checks increase the motivation of people working here'.

\section{Confirmation stage}

The effectiveness of the implementation of pressure ulcer guidelines in daily care must be evaluated. This study investigated this by asking interviewees to describe the obstacles they had to overcome when applying the recommended guidelines in daily practice. In the Dutch nursing homes, the most common mentioned barriers were staff related. First, a shortage of (qualified) staff and lack of nursing staffs' knowledge and/or education were pointed out as barriers. One Dutch nurse (NL7) said: 'We work with a lot of helping aids, these are people that start to work here without any nursing education. They rely on the information they get from the people who have to settle them into the job. I think that they need far more education'. Another obstacle was the lack of motivation to give adequate pressure ulcer care and as well as the stubbornness of some nurses and nursing assistants. A Dutch unit manager (NL16) explains: 'Well, people want to do things their own way, they don't listen to advice or follow suggestions and that, of course, is not the intention, but it's what happens sometimes in daily practice'. Another barrier to give satisfactory pressure ulcer care was non-adherence with the agreed care. For example, nursing staff would forget to change incontinence material when needed or to give extra nutritional support when required. Furthermore sometimes they did not help residents who cannot move by themselves to sit up in wheelchairs. A Dutch nurse (NL2) says: 'What I've noticed lately is that colleagues aren't giving nutritional support to the residents who are supposed to get it. The stuff stays in the fridge, or sometimes they throw it away if it's 
gone past its expiry date, that sort of thing'. Another Dutch nursing assistant (NL14) comments: 'Not everybody pays the same amount of attention to pressure ulcer care. If you pay little or no attention to it, then of course you develop less know-how'.

In Germany, the most frequently mentioned obstacles were related to additional work load. A German head nurse (GER11) says: 'Many colleagues don't see the benefits of gaining extra information about pressure ulcer care, they see it as additional work-load'. Lack of motivation was also brought up. A German nurse (GER2) says: 'My motivation goes down a bit more every time I have to deal with written material, anything put down written on paper'. Another German nurse (GER20) explains: 'Lots of colleagues working part-time don't feel obliged to study the guidelines on pressure ulcer care in their time off work, particularly the nurse aids'. Other obstacles related to staff included gaps of knowledge or unqualified personnel, staff shortages and a lack of nursing education. Shortage of pressure ulcer preventive material, such as pressure-relieving mattresses was another obstacle. Five interviewees encountered no obstacles when implementing the pressure ulcer guideline.

\section{Education}

In the Netherlands, nursing staff was usually trained in-house in pressure ulcer prevention and treatment by the nursing homes since due to financial issues, the possibility for external education was limited. Clinical lessons on the wards and workshops were mentioned as forms of education. None of the homes made it obligatory for nursing staff to follow a specific amount of education. Nursing staff was free to choose their own educational topics, which might have not included the issue of pressure ulcer care. Some nurses and nursing assistants were of the opinion that not enough education was given in the area of pressure ulcer care. None of the homes controlled the amount of pressure ulcer care education taken by nursing staff. A Dutch nursing assistant (NL54) says 'Yes, I think that training should be offered more frequently. People should also be obliged to take courses, some people always sign up, but most don't'.

Some of the interviewees felt that nursing staff had gaps in their knowledge of pressure ulcer care and that more training in this field was needed. A Dutch member of medical staff (NL42) agrees: 'The general level of knowledge about pressure ulcer care is just too low. The problem is always that you have a lot of nursing trainees and often there are no nurses around, only nursing assistants, their knowledge level is just not that high'. In Germany, eight nursing homes offered training in pressure ulcer prevention and treatment to their nursing staff. In most cases, the training was internal, but four nursing homes offered additional external education. Internal training was given in the form of presentations by head nurses, members of the quality and safety department or members from the pressure ulcer working groups and in some nursing homes, physicians, physiotherapists and wound specialist nurses provided training. Education needs were determined by head nurses or ward leaders, who observed these needs during inspections of daily routines. 
Additionally, seven nursing homes subscribed to nursing magazines, but the question is whether these magazines achieved any educational purpose. German head nurse (GER28): 'We have subscriptions to all the important nursing magazines and these are sent out over all the wards, but the problem is whether the nursing staff actually reads these magazines'. Nursing homes offering no training considered their nursing training on pressure ulcer care as sufficient. A German nurse (GER8): 'I think that we have dealt with almost everything, all important topics, during our nursing education'. Furthermore, informing each other during work time was also seen as a way of education. German head nurse (GER4): 'We talk a lot with each other during our shifts; we exchange a lot of information... this way a lot of knowledge is passed on'.

\section{DISCUSSION}

Our qualitative analysis of pressure ulcer guideline dissemination and implementation in Dutch and German nursing homes shows that all Dutch and German nursing homes included in the study have institutional pressure ulcer prevention and treatment guidelines. Strategies used to disseminate pressure ulcer guidelines differed between nursing home as well as by country, varying from placing the guideline on the intranet to making a note in the wards' communication file. Most dissemination strategies involved passive strategies, which have been shown to exert less effect in changing daily care. ${ }^{40-42}$ Some nursing homes in both countries used a multifaceted strategy, whereas others applied only a single strategy. Various studies acknowledge that multifaceted dissemination is a successful approach. ${ }^{40,42}$ However, more recent studies have found it not necessarily more effective than single interventions. ${ }^{43} \mathrm{~A}$ large deviation could be seen between both countries when examining the update procedure of the pressure ulcer guidelines. In most Dutch nursing homes the pressure ulcer guidelines were not updated regularly. The national pressure ulcer guideline, on which Dutch institutional guidelines were mainly based, was last updated in 2001 and some nursing homes have not updated their guidelines since then. ${ }^{23}$ This may lead to the use of outdated prevention and treatment recommendations or lack of awareness of new prevention and treatment recommendations. In contrast, all German nursing homes updated their guideline regularly, varying from yearly to once every four years. This is in accordance with previous studies that recommend updating and reassessing guidelines for validity every three to five years to take into account new research and technologies. ${ }^{44,45}$ Another discrepancy could be seen in the pilot phase of the pressure ulcer guideline. While none of the Dutch nursing homes carried out a pilot, six out of the ten German nursing homes organized a pilot to test the guidelines' utility, practicability and effectiveness. ${ }^{34,46}$

In both countries, obstacles to the implementation of guidelines were mostly related to personnel, additional work load and lack of motivation. These findings are in line with previous studies. ${ }^{18,47}$ Control over the quality of care, in the form of regular care inspections, occurred more frequently in Germany and these inspections were conducted 
internally more often than externally. The German inspections were more related to direct care-giving whereas the Dutch inspections focussed mainly on the managerial/ administrational level.

Education regarding pressure ulcer prevention and treatment for nursing staff was offered in most nursing homes in both countries. However, some of the Dutch interviewees thought that the amount of pressure ulcer education offered at their nursing home was inadequate. When pressure ulcer courses were offered, it was not obligatory to attend them in any of the Dutch nursing homes. No system of ascertaining whether nursing staff had participated in pressure ulcer training courses in past years was available in any of the Dutch nursing homes. Possibly, some Dutch nurses do not take any pressure ulcer training courses and thus the real knowledge level of nursing staff remains unknown, and it is questionable if their knowledge level is indeed adequate and up to date. This doubt is confirmed by the fact that some of the Dutch interviewees stated that knowledge of pressure ulcer care was lacking and more education in this field was needed. This unknown knowledge level of the Dutch nursing staff might have an influence on the differences in pressure ulcer prevalence rates between both countries. Lack of knowledge on adequate pressure ulcer prevention is also noticeable in the answers given by several interviewees. For example some indicated that you do not have to reposition a person lying on a pressure-relieving mattress. This lack of knowledge on pressure ulcer care by nursing home staff is confirmed by previous research, ${ }^{27,29,48,49}$ indicating that the situation has not changed in recent decades. Both the lack of nurses' knowledge as well as the scarcity of nurses' education on pressure ulcer care pointed out in the current study, have been demonstrated by previous studies in other countries. ${ }^{50-52}$ Therefore, lessons learned from this study may be suitable for adoption by other countries.

As described in the method section, the interview samples in the Netherlands and Germany are representative for their country. Nevertheless, the amount of interviewees differed between both countries, which could have resulted in sample bias. Furthermore, investigator predispositions could have led to validity and reliability issues, however independent verification of coding scheme and data coding by two study coauthors minimized these threats.

\section{CONCLUSION}

More attention for the implementation of pressure ulcer guidelines is needed in both Dutch and German nursing homes. Areas for improvement include enhancing the level of nursing staffs' knowledge with regard to pressure ulcer care and increasing awareness for pressure ulcer care. Further research should focus on obstacles to implementing guideline recommendations in daily practice and the gaps in nurses' knowledge with regard to pressure ulcer prevention and treatment in nursing homes. Implementation of pressure ulcer guidelines can influence the prevalence of pressure ulcers. A proper implementation 


\section{Chapter 4}

results in correct application of guideline recommendations and, consequently, in proper pressure ulcer prevention and treatment. 


\section{REFERENCES}

1. De Souza DM, De Gouveia Santos VL. Incidence of pressure ulcers in the institutionalized elderly. Journal of Wound, Ostomy and Continence Nursing 2010;37:272-276.

2. Horn SD, Bender SA, Ferguson ML, Smout RJ, Bergstrom N, Taler G, Cook AS, Sharkey SS, Voss AC. The national pressure ulcer long-term care study: pressure ulcer development in long-term care residents. Journal of the American Geriatrics Society 2004;52:359-367.

3. Vanderwee K, Clark M, Dealey C, Gunningberg L, Defloor T. Pressure ulcer prevalence in Europe: a pilot study. Journal of Evaluation in Clinical Practice 2007;13:227-235.

4. Allman RM, Goode PS, Burst N, Bartolucci AA, Thomas DR. Pressure ulcers, hospital complications, and disease severity: impact on hospital costs and length of stay. Advances in Wound Care 1999;12:22-30.

5. De Laat EHEW, Scholte op Reimer WJ, Van Achterberg T. Pressure ulcers: diagnostics and interventions aimed at wound-related complaints: a review of the literature. Journal of Clinical Nursing 2005;14:464-472.

6. Severens JL, Habraken JM, Duivenvoorden S, Frederiks CMA. The cost of illness of pressure ulcers in the Netherlands. Advances in Skin \& Wound Care 2002;15:72-77.

7. Bours GJJW, Halfens RJG, Lubbers M, Haalboom JRE. The development of a national registration form to measure the prevalence of pressure ulcers in the Netherlands. Ostomy Wound Management 1999;45:28-40.

8. Tannen A, Dassen T, Halfens R. Differences in prevalence of pressure ulcers between the Netherlands and Germany: associations between risk, prevention and occurrence of pressure ulcers in hospitals and nursing homes. Journal of Clinical Nursing 2008;17:1237-1244.

9. Tannen A, Dietz E, Dassen T, Halfens R. Explaining the national differences in pressure ulcer prevalence between the Netherlands and Germany: adjusted for personal risk factors and institutional quality indicators. Journal of Evaluation in Clinical Practice 2009;15:85-90.

10. National Institute for Health and Clinical Excellence. Pressure ulcers: the management of pressure ulcers in primary and secondary care. London: National Institute for Health and Clinical Excellence; 2005.

11. National Pressure Ulcer Advisory Panel and European Pressure Ulcer Advisory Panel. Prevention and treatment of pressure ulcers: clinical practice guideline. Washington DC: National Pressure Ulcer Advisory Panel; 2009.

12. Registered Nurses Association of Ontario. Risk assessment \& prevention of pressure ulcers. Toronto: Registered Nurses Association of Ontario; 2005.

13. Ayello E, Sibbald R. Preventing pressure ulcers and skin tears. In: Capezuti E, Zwicker D, Mezey M, Fulmer T, eds. Evidence-based Geriatric Nursing Protocols for Best Practice. 3rd ed. New York: Springer Publishing Company; 2008, 403-429.

14. Registered Nurses Association of Ontario. Assessment and management of stage I to IV pressure ulcers. Toronto: Registered Nurses Association of Ontario; 2007.

15. Clark M. Barriers to the implementation of clinical guidelines. Journal of Tissue Viability 2003;13:62-72.

16. Gunningberg L. Risk, prevalence and prevention of pressure ulcers in three Swedish health-care settings. Journal of Wound Care 2004;13:286-290.

17. Meijers JMM, Schols JMGA, Jackson PA, Langer G, Clark M, Halfens RJG. Evaluation of the dissemination and implementation of a nutritional guideline for pressure ulcer care. Journal of Wound Care 2007;16:201-205.

18. Moore Z, Price P. Nurses' attitudes, behaviours and perceived barriers towards pressure ulcer prevention. Journal of Clinical Nursing 2004;13:942-951. 
19. Paquay L, Wouters R, Defloor T, Buntinx F, Debaillie R, Geys L. Adherence to pressure ulcer prevention guidelines in home care: a survey of current practice. Journal of Clinical Nursing 2008;17:627-636.

20. Parahoo K. Barriers to, and facilitators of, research utilization among nurses in Northern Ireland. Journal of Advanced Nursing 2000;31:89-98.

21. Grol R, Wensing M. What drives change? Barriers to and incentives for achieving evidencebased practice. Medical Journal of Australia 2004;180:S57-S60.

22. Grol R, Grimshaw J. From best evidence to best practice: effective implementation of change in patients' care. The Lancet 2003;362:1225-1230.

23. Centraal Begeleidingsorgaan voor de Intercollegiale Toetsing. Decubitus. Tweede herziening Alphen aan den Rijn: Van Zuiden; 2002.

24. Deutsches Netzwerk für Qualitätsentwicklung in der Pflege. Expertenstandard Dekubitusprophylaxe in der Pflege. Entwicklung - Konsentierung - Implementierung 2. Auflage mit aktualisierter Literaturstudie (1999-2002). Osnabrück: Deutsches Netzwerk für Qualitätsentwicklung in der Pflege; 2004.

25. Meesterberends E, Halfens R, Lohrmann C, De Wit R. Pressure ulcer guideline development and dissemination in Europe Journal of Clinical Nursing 2010;19:1495-1503.

26. Bours GJJW, Halfens RJG, Huijer Abu-Saad H, Grol RTPM. Prevalence, prevention and treatment of pressure ulcers: descriptive study in 89 institutions in the Netherlands. Research in Nursing \& Health 2002;25:99-110.

27. Halfens RJG, Eggink M. Knowledge, beliefs and use of nursing methods in preventing pressure sores in Dutch hospitals. International Journal of Nursing Studies 1995;32:16-26.

28. Inspectie voor de Gezondheidszorg. Decubitus doorgelicht: richtlijn onvoldoende in praktijk toegepast: een onderzoek naar de kwaliteit van de decubituszorg in Nederland en maatregelen om het aantal patiënten met decubitus te verminderen. Den Haag: Inspectie voor de Gezondheidszorg; 2004.

29. Wilborn D, Dassen T. Pressure ulcer prevention in German healthcare facilities: adherence to national expert standard? Journal of Nursing Care Quality 2010;25:151-159.

30. Halfens RJG, Meijers JMM, Neyens JCL, Offermans MPW. Rapportage resultaten: Landelijke Prevalentiemeting Zorgproblemen 2007. Maastricht: Universiteit Maastricht; 2007.

31. Dassen T, Lahmann N, Böhse S, Petermann B, Heinze C, Kottner J, Mertens E, Schmitz G, Tannen A, Wilborn D. Pflegeabhängigkeit, Sturzereignisse, Inkontinenz, Dekubitus: Prävalenz Erhebung 2007. Berlin: Charité; 2007.

32. Rogers EM. Diffusion of innovations, 5th edition. New York: The Free Press; 2003

33. Cluzeau F, Littlejohns P, Grimshaw J, Feder G. Appraisal instrument for clinical guidelines, version 1. London: St. George's Hospital Medical School; 1997.

34. The AGREE Collaboration. Development and validation of an international appraisal instrument for assessing the quality of clinical practice guidelines: the AGREE project. Quality and Safety in Health Care 2003;12:18-23.

35. National Health and Medical Research Council. A guide to the development, implementation and evaluation of clinical practice guidelines. Canberra: National Health and Medical Research Council; 1999.

36. National Health and Medical Research Council. How to put the evidence into practice: implementation and dissemination strategies. Canberra: National Health and Medical Research Council; 2000.

37. National Health Service Centre for Reviews and Dissemination. Getting evidence into practice. Effective Health Care 1999;5:1-16.

38. Berg B. Qualitative research methods for the social sciences, 5th edn. Boston MA: Pearsons Education Inc; 2004. 
39. Nederlandse Vereniging van Verpleeghuisartsen. Tripartiete multidisciplinaire richtlijn: samenwerking en logistiek rond decubitus. Utrecht: Nederlandse Vereniging van Verpleeghuisartsen; 2003.

40. Davis DA, Taylor-Vaisey A. Translating guidelines into practice: a systematic review of theoretic concepts, practical experience and research evidence in the adoption of clinical practice guidelines. Canadian Medical Association Journal 1997;157:408-416.

41. Feder G, Eccles M, Grol R, Griffiths C, Grimshaw J. Using clinical guidelines. British Medical Journal 1999;318:728-730.

42. Oxman AD, Thomson MA, Davis DA, Haynes B. No magic bullets: a systematic review of 102 trials of interventions to improve professional practice. Canadian Medical Association Journal 1995;153:1423-1431.

43. Grimshaw JM, Thomas RE, MacLennan G, Fraser C, Ramsay CR, Vale L, Whitty P, Eccles MP, Matowe L, Shirran L, Wensing M, Dijkstra R, Donaldson C. Effectiveness and efficiency of guideline dissemination and implementation strategies. Health Technology Assessment 2004;8:341-352.

44. Grol R, Wensing M. Implementatie: Effectieve verandering in de patiëntenzorg. Maarssen: Elsevier gezondheidszorg; 2001.

45. Shekelle PG, Ortiz E, Rhodes S, Eccles M, Grimshaw J, Woolf SH. Validity of the Agency for Healthcare Research and quality clinical practice guidelines: how quickly do guidelines become outdated? Journal of the American Medical Association 2001;286:1461-1467.

46. Duff LA, Kitson AL, Seers K, Humphris D. Clinical guidelines: an introduction to their development and implementation. Journal of Advanced Nursing 1996;23:887-895.

47. Clarke HF, Bradley C, Whytock S, Handfield S, Van der Wal R, Gundry S. Pressure ulcers: implementation of evidence-based nursing practice. Journal of Advanced Nursing 2005;49:578590.

48. Buss IC, Halfens RJG, Huijer Abu-Saad H, Kok G. Pressure ulcer prevention in nursing homes: views and beliefs of enrolled nurses and other health care workers. Journal of Clinical Nursing 2004;13:668-676.

49. Hulsenboom MA, Bours GJ, Halfens RJ. Knowledge of pressure ulcer prevention: a crosssectional and comparative study among nurses. BMC Nursing 2007;6.

50. Benbow M. Quality of life and pressure ulcers. Journal of Community Nursing 2009;23:14-18.

51. Panagiotopoulou K, Kerr SM. Pressure area care: an exploration of Greek nurses' knowledge and practice. Journal of Advanced Nursing 2002;40:285-296.

52. Pieper B, Mott M. Nurses' knowledge of pressure ulcer prevention, staging, and description. Advances in Wound Care 1995;8:34-38. 


\section{CHAPTER 5}

\section{PRESSURE ULCER INCIDENCE IN DUTCH AND GERMAN NURSING HOMES: DESIGN OF A PROSPECTIVE MULTICENTER COHORT STUDY}




\section{ABSTRACT}

Background. Pressure ulcers are a common and serious health care problem in all health care settings. Results from annual national pressure ulcer prevalence surveys in the Netherlands and Germany reveal large differences in prevalence rates between both countries over the past ten years, especially in nursing homes. When examining differences in prevalence and incidence rates, it is important to take into account all factors associated with the development of pressure ulcers. Numerous studies have identified patient related factors, as well as nursing related interventions as risk factors for the development of pressure ulcers. Next to these more process oriented factors, also structural factors such as staffing levels and staff quality play a role in the development of pressure ulcers. This study has been designed to investigate the incidence of pressure ulcers in nursing homes in the Netherlands and Germany and to identify patient related factors, nursing related factors and structural factors associated with pressure ulcer development. The present article describes the protocol for this study.

Methods and design. A prospective multicenter study is designed in which a cohort of newly admitted nursing home residents in 10 Dutch and 11 German nursing homes will be followed for a period of 12 weeks. Data will be collected by research assistants using questionnaires on four different levels: resident, staff, ward, and nursing home.

Discussion. The results of the study will provide information on the incidence of pressure ulcers in Dutch and German nursing homes. Furthermore, information will be gathered on the influence of patient related factors, nursing related factors and structural factors on the incidence of pressure ulcers. The present article describes the study design and addresses the study's strengths and weaknesses. 


\section{INTRODUCTION}

Pressure ulcers are a common and serious health care problem in all health care settings. ${ }^{1-4}$ A pressure ulcer is defined as 'a localised injury to the skin and/or underlying tissue usually over a bony prominence, as a result of pressure, or pressure in combination with shear' ${ }^{5}$ Pressure ulcers can result in a decreased quality of life, an increased need for intensive nursing and medical care and a rise in morbidity and mortality rates. ${ }^{1,2}$ Studies around the world have reported large differences in pressure ulcer prevalence rates, varying from $4.7 \%$ to $22.9 \%$ in hospitals ${ }^{3,4,6}$ and $7.7 \%$ to $83.6 \%$ in nursing homes. ${ }^{6,7}$

Results from annual national pressure ulcer prevalence surveys in the Netherlands and Germany, which use the same standardized definitions, instruments and methodology, have also revealed large differences in prevalence rates between both countries over the past ten years, especially in nursing homes. ${ }^{9,10}$ Rates in Dutch nursing homes $(30.8 \%)$ are reported to be over three times as high compared to those in German nursing homes $(8.3 \%) .^{10}$

When examining differences in prevalence and incidence rates, it is important to take into account all factors associated with the development of pressure ulcers. Various studies have identified a number of patient related factors as risk factors for the development of pressure ulcers. These patient related factors include age ${ }^{11}$; limited mobility and activity levels ${ }^{12,13}$; medical conditions/diseases such as diabetes mellitus ${ }^{13}$, Alzheimer disease ${ }^{14}$, and cardiovascular diseases ${ }^{15}$; orthopedic problems $^{13}$; medications such as sedatives, analgesics and anesthetics ${ }^{16}$; malnutrition $^{17}$; skin moisture ${ }^{16}$; and urinary and fecal incontinence. ${ }^{18}$ Besides patient related factors, nursing related interventions such as the application of repositioning $^{1}$ and the performance of nutritional care ${ }^{19,20}$ are also linked to the development of pressure ulcers. Furthermore, besides these more process oriented factors, structural factors ${ }^{21}$, such as staffing levels, staff quality and the presence and the use of pressure ulcer guidelines ${ }^{22-24}$, also play a role in the development of pressure ulcers. This study has been designed to investigate whether the incidence of pressure ulcers differs between nursing homes in the Netherlands and Germany and, if so, to identify which patient related factors, nursing related factors and structural factors are associated with pressure ulcer development. A detailed description of the methodology of this study is given in this paper.

\section{METHODS/DESIGN}

\section{Study design}

This study has been set up as a prospective multicenter cohort study and will be carried out in 10 nursing homes in the Netherlands and 11 nursing homes in Germany. All newly admitted residents in these nursing homes who fulfill the inclusion criteria will be included for participation. In total, 600 residents (300 in each country) will be recruited. Residents 
who give their informed consent are followed for a period of 12 weeks. This period of 12 weeks was chosen because the national prevalence measurement of care problems in the Netherlands in 2007 showed that $18.3 \%$ of nursing home residents developed a pressure ulcer within 12 weeks after admission. ${ }^{25}$

\section{Setting}

The participating nursing homes in the Netherlands were selected through the 2008 national prevalence measurement of care problems database. ${ }^{26}$ This database contains pressure ulcer prevalence rates from $53 \%$ of the Dutch nursing homes. In Germany, nursing homes were selected through the government database for the federal states of Berlin and Brandenburg. Nursing homes could be included in the study if they had a capacity of more than 50 beds and, for practical reasons, were located in the regions Limburg or Brabant (the Netherlands) or Berlin and Brandenburg (Germany). Nursing homes that met these inclusion criteria were entered into SPSS version 17, and subsequently 10 Dutch and 11 German nursing homes were chosen at random by using the 'select cases' option. Rehabilitation and palliative wards were excluded from participation in the study, since the average length of time that residents stay on these wards is short.

\section{Participants}

Only newly admitted nursing home residents are included in this study. Residents are not excluded if they have a pressure ulcer, but are excluded from participation if they have an expected nursing home stay of less than 3 months, if they have been diagnosed with a terminal illness or if their informed consent is received later than three weeks after their admission to the nursing home. All newly admitted residents (and relatives for psycho geriatric residents) who meet the inclusion criteria receive an information package and an informed consent letter during their interview on admission to the nursing home.

\section{Data collection instruments}

Data will be collected using questionnaires on four different levels: resident, ward, nursing home and staff level. For the resident, ward and nursing home levels, most questions are adapted from the Dutch LPZ questionnaires. ${ }^{26}$ These questionnaires were developed for the annual national prevalence measurement of care problems, and are based on information gathered from literature reviews and a Delphi panel of pressure ulcer care experts. ${ }^{5}$ The reliability and validity of these questionnaires have been proven in earlier research. ${ }^{7}$ The following section describes the questionnaires and instruments used on the four different levels. 


\section{Resident level}

On the resident level, a number of different questionnaires and instruments are used. An overview of the different instruments and time points can be seen in Table 5.1.

Table 5.1 Overview of instruments and questionnaires on resident level per time point.

\begin{tabular}{|c|c|c|c|c|c|}
\hline & $\begin{array}{l}\text { Resident } \\
\text { questionnaire }\end{array}$ & $\begin{array}{l}\text { Pressure } \\
\text { questionnaire }^{1}\end{array}$ & ulcer Braden Scale & $\begin{array}{l}\text { Care Dependency } \\
\text { Scale (CDS) }\end{array}$ & $\begin{array}{l}\text { Mini Nutritional } \\
\text { Assessment } \\
(\mathrm{MNA})^{2}\end{array}$ \\
\hline Week 1 & $x$ & $x$ & $x$ & & \\
\hline Week 2 & $x$ & $x$ & $x$ & & \\
\hline Week 3 & $x$ & $x$ & $x$ & & \\
\hline Week 4 & $x$ & $x$ & $x$ & $x$ & $x$ \\
\hline Week 5 & $x$ & $x$ & $x$ & & \\
\hline Week 6 & $x$ & $x$ & $x$ & & \\
\hline Week 7 & $x$ & $x$ & $x$ & & \\
\hline Week 8 & $x$ & $x$ & $x$ & $x$ & $x$ \\
\hline Week 9 & $x$ & $x$ & $x$ & & \\
\hline Week 10 & $x$ & $x$ & $x$ & & \\
\hline Week 11 & $x$ & $x$ & $x$ & & \\
\hline Week 12 & $\mathrm{x}$ & $\mathrm{x}$ & $x$ & $x$ & $x$ \\
\hline
\end{tabular}

${ }^{1}$ Filled in if the resident has one (or more) pressure ulcer(s); ${ }^{2}$ Filled in if the resident has lost more than $5 \%$ of body weight during the past month

\section{Resident questionnaire}

The resident questionnaire contains questions about demographic data (sex, age, gender, weight, length), diseases, reason for nursing home admission, medication use, care dependency, mental status, existence of pressure ulcer(s) (yes/no), repositioning, mobilization, skin care and skin inspection, use of mattresses and cushions, nutrition and prevention of malnutrition and incontinence care.

Answers are obtained by speaking to the residents directly or, if not possible, by consulting a responsible nurse or nursing assistant and/or the resident documentation. Information about the existence of pressure ulcers is collected by physical examinations conducted by research assistants. The resident questionnaire is filled in weekly for each resident for a period of 12 weeks.

\section{Pressure ulcer questionnaire}

The pressure ulcer questionnaire contains questions (per pressure ulcer) about the location and the duration of the pressure ulcer and the setting where the pressure ulcer was developed (in the current nursing home, in another nursing home, in the hospital, at home or elsewhere). For pressure ulcer grading, the grading system of the European Pressure Ulcer Advisory Panel is used. ${ }^{27}$ The length and width of the wound are measured with the perpendicular method using a wound ruler in centimeters. The extension of 
wound undermining and the depth of the wounds are examined using sterile cotton buds. The wound bed is classified as black (necrotic tissue), yellow (fibrin or slough tissue), red (granulation tissue) or pink (epithelial issue). If $100 \%$ of the tissue is pink, this indicates a resurfaced wound. The exudate is classified as none, light, moderate or heavy. ${ }^{28}$ Furthermore, the pressure ulcer healing process is monitored using the scores of the Pressure Ulcer Scale for Healing (PUSH Tool 3.0). ${ }^{29}$ The wound edge can be described as smooth, rugged, reddened, pale, inflamed or macerated, since no valid or reliable measuring instruments exist. ${ }^{30}$ The wound environment can be described as normal, dry, flaky, humid or inflamed. The odour of the exudate can be qualified as conspicuous or inconspicuous and the quality of the exudate as serous, bloody-serous or purulent. Additionally, information is gained about the treatment of the pressure ulcer (primary and secondary) based on Vasel-Biergans $(2006)^{31}$ and whether the resident perceives any pain (0-10 Likert scale).

The PUSH tool was developed by the National Pressure Ulcer Advisory Panel as a quick, reliable tool to monitor the change in pressure ulcer status over time. The tool has been validated by several studies and includes the length and width of the wound in $\mathrm{cm}^{2}$ with a scoring range from 0 to 10 , the amount of exudate and the tissue type. The total score ranges from 0 to 17 and helps to indicate improvement or deterioration in pressure ulcer healing. ${ }^{29}$ The pressure ulcer questionnaire is filled in weekly if the resident has a pressure ulcer. A separate form is used for each pressure ulcer.

\section{Braden scale}

The Braden scale is a scale used for determining the risk of pressure ulcer development in patients. The scale, developed in 1984, is one of the most used pressure ulcer risk scales and has a proved validity and reliability. ${ }^{32,33}$ The scale consists of six subscales: sensory perception, activity level, mobility, nutritional status, skin's exposure to moisture and friction and shear forces. On each subscale (except friction and shear), scores from 1 to 4 can be given, with 4 representing the highest level. On the friction and shear subscale, scores range from 1 to 3 . Total Braden scale scores can range from 6 to 23, with lower total scores indicating a higher risk of developing a pressure ulcer. ${ }^{32}$ The Braden scale has been translated into Dutch and German, and several studies have shown the Dutch and German versions of the Braden scale to be valid and reliable. ${ }^{34,35}$ The Braden scale is filled in for each resident weekly by the research assistants.

\section{Care Dependency Scale}

The Care Dependency Scale (CDS) provides a framework for the care dependency status of institutionalized elderly people. It was developed in the Netherlands and has proven validity and reliability. ${ }^{36,37}$ The CDS measures 15 concepts of human needs: eating and drinking, incontinence, body posture, mobility, day/night pattern, getting dressed and undressed, body temperature, hygiene, avoidance of danger, communication, contact with others, sense of rules and values, daily activities, recreational activities and learning 
ability. The care dependency is assessed on a five-point Likert scale. A CDS sum score can be computed by adding the item score of the 15 items and ranges from 15 to 75 . Low scores on the scale items indicate that the patient is completely dependent on care; high scores indicate that the patient is almost independent of care. ${ }^{37,38}$ The CDS has been translated into several languages, including German [39]. It has been tested in several studies and proven appropriate for use in nursing home practice and for international comparisons of care dependency. ${ }^{38,39}$ The CDS is filled in every four weeks (weeks 4,8 and 12).

\section{Mini Nutritional Assessment}

The Mini Nutritional Assessment (MNA) is a validated and reliable instrument, with a high sensitivity and specificity, used to identify elderly residents who are malnourished or who are at risk for malnutrition. ${ }^{40,41}$ The MNA is composed of 18 items and involves anthropometric, general, dietary and subjective assessments. ${ }^{42}$ The MNA classifies individuals into three levels of nutritional status on the basis of scores that range from 0 to 30. A score of 24 or greater indicates satisfactory nutritional status, a score between 17 and 23.5 indicates a risk of malnutrition, and a score below 17 indicates protein energy malnutrition. ${ }^{41}$ The MNA is conducted if a resident has lost more than $5 \%$ of body weight during the past month.

\section{Staff level}

The staff questionnaire was developed to measure the knowledge and practice among nurses and nursing assistants regarding pressure ulcer preventive measures. ${ }^{43}$ The questionnaire consists of three different parts. The first part contains questions about the respondents' demographic characteristics, such as age, education and years of working experience in the area of care. The second and third parts of the questionnaire contain questions about the knowledge and practice of nurses and nursing assistants regarding pressure ulcer prevention. These questions are based on the 2002 Dutch national guideline on pressure ulcers ${ }^{44}$, which divides pressure ulcer preventive measures into two categories. The first category includes 16 measures that are useful to prevent pressure ulcers for all patients at risk, such as ensuring good hygiene. The second category comprises 13 measures that are not useful to prevent pressure ulcers, such as using gel mattresses and pillows.

In the second part of the questionnaire, the respondents are asked to judge all 29 preventive measures whether they would apply these for patients who are at risk for developing a pressure ulcer. The answering categories for each preventive measure are 'always', 'sometimes' and 'never'. In the third part of the questionnaire, the respondents are asked to judge the usefulness of the preventive measures for patients who are at risk for developing a pressure ulcer. Answering categories for each measure are 'useful', 'sometimes useful', 'not useful' or 'do not know'. 


\section{Ward level}

The ward questionnaire contains questions about the type of ward, the number of residents and rooms on the ward, ward specialization, staffing, presence of pressure ulcer guidelines and whether there is a tissue viability nurse working at the nursing home.

\section{Nursing home level}

The nursing home questionnaire includes questions about the number of residents in the nursing home, type of specialization and certification of the nursing home, staffing (full time equivalents and qualifications), refresher courses in pressure ulcer care (internal and external), quality control (internal and external) and presence of pressure ulcer guidelines.

\section{Data collection methodology}

Research assistants are responsible for collecting the data among the nursing home residents. In total, three research assistants are responsible for the data collection in the Netherlands and eleven in Germany. All research assistants are nurses or physiotherapists and are educated in the area of pressure ulcer care. All have been trained and instructed to collect the data for this study.

The ward questionnaires are to be filled in by the head of the department. The nursing home questionnaires are to be filled in by the nursing home manager. Both questionnaires are to be completed within a month after the start of the study. Both the ward and nursing home questionnaires are sent back to the principal researchers in both countries by means of stamped addressed envelopes. The staff questionnaires are to be completed by nurses and nursing assistants on the participating wards within the first two months of the study. These questionnaires are collected by the research assistants.

\section{Sample size calculation}

A sample size calculation was performed to determine the number of people who develop a pressure ulcer. To detect a $5 \%$ difference in pressure ulcer incidence between both countries (alpha $=0.05$; beta $=0.2$ ), with a $15 \%$ estimated drop-out rate, 562 residents (280 in each country) need to be recruited.

\section{Data analysis}

Data will be checked for outliers and normality. The analysis includes descriptive frequency distributions for all variables. The level of statistical significance is set at alpha 0.01 (two-tailed). The dependent variable is the development of a pressure ulcer during the 12-week study period for each resident. Bivariate analyses, using cross-tabulations and chi-square tests for nominal data and two sample Wilcoxon tests for continuous data, will be performed to compare each suggested predictor with the dependent variable.

The study will use multilevel models in which 12 repeated measures (the level 1 units) are nested within residents (level 2 units). Multilevel models can accommodate data that are 
unbalanced due to attrition or missing values. Multivariate Cox regression analyses are used to determine the association between resident, treatment, and facility characteristics and the outcome. All statistical analyses will be performed using Predictive Analytics SoftWare (PASW) version 17 from SPSS.

\section{Ethical considerations}

The medical ethical committees of the Maastricht University Medical Hospital and the Charite - Universitätsmedizin Berlin have granted full ethical approval for this study. The privacy of the participating residents is protected and all data is coded and processed anonymously.

\section{Time plan}

The nursing homes for this study have already been selected. In the Netherlands, 119 nursing homes met the inclusion criteria. In the first stage, eight of the ten selected nursing homes and, in the second stage, two of the four selected nursing homes were willing to take part in the study. In Germany, 288 nursing homes met the inclusion criteria. In the first stage, six of the ten selected nursing homes were willing to take part in the study; in the second stage one, in the third stage two and in the fourth stage two of the eight selected nursing homes were willing to take part in the study. Resident recruitment began in June 2009 (GER) and August 2009 (NL). The study will be completed in September 2011.

\section{DISCUSSION}

This study has been designed to identify whether there are differences in pressure ulcer incidence rates between nursing homes in the Netherlands and Germany. Additionally, the study will reveal whether these differences can be explained by factors related to patients, nursing care or nursing home structure. To date, many studies concerning pressure ulcer care have a cross-sectional or retrospective design; these designs make it difficult to investigate which factors influence the onset of pressure ulcers because they cannot provide insight into causal relationships. The prospective and longitudinal design of this study will allow us to investigate these factors. Moreover, the longitudinal and prospective design is less vulnerable to measurement error, which is a risk in crosssectional or retrospective studies. ${ }^{45,46}$

To the present authors' knowledge, this study is the first to assess patient related, nursing related and structure related factors in one study. Most previous studies on pressure ulcer care have focused on only one of these factors. The present study makes it possible to gain better insight into all factors related to patients, nursing care and structure that may influence pressure ulcer prevalence and incidence rates and their interactions. Moreover, many studies on pressure ulcer care obtain data about the existence of pressure ulcers by 
means of nursing documentation, or analyze data gathered by staff working in the health care institutions. In the present study, all information about the existence of pressure ulcers will be gathered by means of concrete physical examinations carried out by external research assistants to ensure the reliability of the data. Furthermore, the intended sample size and the involvement of multiple nursing homes will improve the reliability of the results.

The internal validity of the study results may be limited due to the exclusion criteria. For example, residents who have an expected nursing home stay of less than 12 weeks will not be included. Additionally, it is possible that participating residents have other clinical characteristics than non-participating residents. For example, non-participating residents may have worse physical conditions than participating residents. Nevertheless, the risk for selection bias will be reduced by the participation of multiple nursing homes in both countries. Although nursing homes were selected from specific regions in both countries, the nursing homes are representative for their country as they differ in size, foundation and specialization. Finally, the drop-out rate of residents during the study due to death, admittance to the hospital or transfer to another nursing home may influence the study results. Drop-outs will be documented thoroughly and included in the data analysis to the point of drop-out. 


\section{REFERENCES}

1. De Laat EHEW, Scholte op Reimer WJ, Van Achterberg T. Pressure ulcers: diagnostics and interventions aimed at wound-related complaints: a review of the literature. Journal of Clinical Nursing 2005;14:464-472.

2. Allman RM. Pressure ulcer prevalence, incidence, risk factors, and impact. Clinics in Geriatric Medicine 1997;13:421-436.

3. Allman RM, Laprade CA, Noel LB, Walker JM, Moorer CA, Dear MD, Smith CS. Pressure sores among hospitalized patients. Annals of Internal Medicine 1986;105:337-342.

4. Bours GJJW, Halfens RJG, Huijer Abu-Saad H, Grol RTPM. Prevalence, prevention and treatment of pressure ulcers: descriptive study in 89 institutions in the Netherlands. Research in Nursing \& Health 2002;25:99-110.

5. European Pressure Ulcer Advisory Panel and National Pressure Ulcer Advisory Panel. Prevention and treatment of pressure ulcers: quick reference guide. Washington DC: National Pressure Ulcer Advisory Panel; 2009.

6. Halfens RJG, Meijers JMM, Du Moulin MFMT, Van Nie NC, Neyens JCL, Schols JMGA. Rapportage resultaten: Landelijke Prevalentiemeting Zorgproblemen 2010. Maastricht: Maastricht University; 2010.

7. Bours GJJW, Halfens RJG, Lubbers M, Haalboom JRE. The development of a national registration form to measure the prevalence of pressure ulcers in the Netherlands. Ostomy Wound Management 1999;45:28-40.

8. Dassen T, Petermann B, Heinze C, Lahmann N, Lohrmann C, Mertens E, Tannen A. Dekubitus, Sturzereignisse, Pflegeabhängigkeit: Prävalenzerhebung 2002. Berlin: Institut für Medizin/Pflegepädagogik und Pflegewissenschaft; 2002.

9. Tannen A, Dassen T, Halfens R. Differences in prevalence of pressure ulcers between the Netherlands and Germany: associations between risk, prevention and occurrence of pressure ulcers in hospitals and nursing homes. Journal of Clinical Nursing 2008;17:1237-1244.

10. Tannen A, Dietz E, Dassen T, Halfens R. Explaining the national differences in pressure ulcer prevalence between the Netherlands and Germany: adjusted for personal risk factors and institutional quality indicators. Journal of Evaluation in Clinical Practice 2009;15:85-90.

11. Gunningberg L, Lindholm C, Carlsson M, Sjöden PO. Reduced incidence of pressure ulcers in patients with hip fractures: a 2-year follow-up of quality indicators. International Journal for Quality in Health Care 2001;13:399-407.

12. Lindgren M, Unosson M, Fredrikson M, Ek AC. Immobility: a major risk factor for development of pressure ulcers among adult hospitalized patients: a prospective study. Scandinavian Journal of Caring Sciences 2004;18:57-64.

13. Haleem S, Heinert G, Parker MJ. Pressure sores and hip fractures. Injury 2008;39:219-223.

14. Zulkowski K. MDS+ RAP items associated with pressure ulcer prevalence in newly institutionalized elderly: study I. Ostomy Wound Management 1998;44:40-53.

15. Capon A, Pavoni N, Mastromattei A, Di Lallo D. Pressure ulcer risk in long-term units: prevalence and associated factors. Journal of Advanced Nursing 2007;58:263-272.

16. Grey JE, Harding KG, Enoch S. Pressure ulcers. British Medical Journal 2006;332:472-475.

17. VanGilder C, Macfarlane G, Meyer S, Lachenbruch C. Body Mass Index, weight, and pressure ulcer prevalence: an analysis of the 2006-2007 international pressure ulcer prevalence surveys. Journal of Nursing Care Quality 2009;24:127-135.

18. Achterberg WP, Frijters DH, Ribbe MW. Het vóórkomen van ulcera in verpleeghuizen. Tijdschrift voor Gerontologie en Geriatrie 2008;39:115-121.

19. Elia M, Zellipour L, Stratton RJ. To screen or not to screen for adult malnutrition? Clinical Nutrition 2005;24:867-884. 
20. Posthauer ME. The role of nutrition in wound care. Advances in Skin \& Wound Care 2006;19:43-52.

21. Donabedian A. Institutional and professional responsibilities in quality assurance. Quality Assurance in Health Care 1989;1:3-11.

22. Hickey EC, Young GJ, Parker VA, Czarnowski EJ, Saliba D, Berlowitz DR. The effects of changes in nursing home staffing on pressure ulcer rates. Journal of the American Medical Directors Association 2005;6:50-53.

23. De Laat EH, Pickkers P, Schoonhoven L, Verbeek AL, Feuth T, Van Achterberg T. Guideline implementation results in a decrease of pressure ulcer incidence in critically ill patients. Critical Care Medicine 2007;35:815-820.

24. Alexander GL. An analysis of nursing home quality measures and staffing. Quality Management in Health Care 2008;17:242-251.

25. Halfens RJG, Meijers JMM, Neyens JCL, Offermans MPW. Rapportage resultaten: Landelijke Prevalentiemeting Zorgproblemen 2007. Maastricht: Maastricht University; 2007.

26. Halfens RJG, Meijers JMM, Neyens JCL, Offermans MPW. Rapportage resultaten: Landelijke Prevalentiemeting Zorgproblemen 2008. Maastricht: Maastricht University; 2008.

27. European Pressure Ulcer Advisory Panel (1998) Pressure ulcer prevention and treatment guidelines; www.epuap.org.

28. Deutsches Netzwerk für Qualitätsentwicklung in der Pflege. Expertenstandard Pflege von Menschen mit Chronischen Wunden Entwicklung - Konsentierung - Implementierung. Osnabrück: Deutsches Netzwerk für Qualitätsentwicklung in der Pflege; 2009.

29. Thomas DR, Rodeheaver GT, Bartolucci AA, Franz RA, Sussman C, Ferrell BA, Cuddigan J, Stotts NA, Maklebust J. Pressure ulcer scale for healing: derivation and validation of the PUSH tool. Advances in Wound Care 1997;10:96-101.

30. Panfil EM, Linde E. Valide und reliable Methoden zur Wundbeschreibung von Dekubitus und Ulcus cruris: eine systematische Literaturübersicht. Pflege 2007;20:225-247.

31. Vasel-Biergans A. Wundauflagen für die kitteltasche von, 2. erweiterte Auflage. Stuttgart: Wissenschaftliche Verlagsgesellschaft mbH; 2006.

32. Bergstrom N, Braden BJ, Laguzza A, Holman V. The Braden scale for predicting pressure sore risk. Nursing Research 1987;36:205-210.

33. Braden BJ, Bergstrom N. Predictive validity of the Braden scale for pressure sore risk in a nursing home. Research in Nursing \& Health 1994;17:459-470.

34. Halfens RJG, Van Achterberg T, Bal RM. Validity and reliability of the Braden scale and the influence of other risk factors: a multi-centre prospective. International Journal of Nursing Studies 2000;37:313-319.

35. Balzer K, Pohl C, Dassen T, Halfens R. The Norton, Waterlow, Braden, and care dependency scales: comparing their validity when identifying patients' pressure sore risk. Journal of Wound Ostomy and Continence Nursing 2007;34:389-398.

36. Dijkstra A. Care dependency, an assessment instrument for use in long-term care facilities, PhD thesis. Groningen; 1998.

37. Dijkstra A, Buist G, Dassen T, van den Heuvel W. Het meten van zorgafhankelijkheid met de ZorgAfhankelijkheidsSchaal, Care Dependency Scale (CDS): een handleiding. Groningen; 1999.

38. Dijkstra A, Brown L, Havens B, Romeren TI, Zanotti R, Dassen T, van den Heuvel W. An international psychometric testing of the care dependency scale. Journal of Advanced Nursing 2000;31:944-952.

39. Lohrmann C, Dijkstra A, Dassen T. Care dependency: testing the German version of the Care Dependency Scale in nursing homes and on geriatric wards. Scandinavian Journal of Caring Sciences 2003;17:51-56. 
40. Guigoz Y, Vellas B, Garry PJ. Mini Nutritional Assessment: a practical assessment tool for grading the nutritional state of elderly patients. Facts and Research in Gerontology 1994;suppl.2:15-59.

41. Vellas B, Lauque S, Andrieu S, Nourhashemi F, Rolland Y, Baumgartner R, Garry P. Nutrition assessment in the elderly. Current Opinion in Clinical Nutrition and Metabolic Care 2001;4:5-8.

42. Guigoz Y, Vellas B, Garry PJ. Assessing the nutritional status of the elderly: The Mini Nutritional Assessment as part of the geriatric evaluation. Nutrition Reviews 1996;54:S59-65.

43. Hulsenboom MA, Bours GJ, Halfens RJ. Knowledge of pressure ulcer prevention: a crosssectional and comparative study among nurses. BMC Nursing 2007;6.

44. Centraal Begeleidingsorgaan voor de Intercollegiale Toetsing. Decubitus. Tweede herziening. Alphen aan den Rijn: Van Zuiden; 2002.

45. Hudson JI, Pope HG, Jr., Glynn RJ. The cross-sectional cohort study: an underutilized design. Epidemiology 2005;16:355-359.

46. White E, Hunt JR, Casso D. Exposure measurement in cohort studies: The challenges of prospective data collection. Epidemiologic Reviews 1998;20:43-56. 


\section{CHAPTER 6}

KNOWLEDGE AND USE OF PRESSURE ULCER PREVENTIVE MEASURES IN NURSING HOMES: A COMPARISON OF DUTCH AND GERMAN NURSING STAFF 


\section{ABSTRACT}

Aims and objectives. To examine the knowledge and use of pressure ulcer preventive measures among nursing staff in Dutch and German nursing homes.

Background. Studies in the Netherlands and Germany have shown a large discrepancy in pressure ulcer prevalence rates among nursing homes in both countries and concluded that some of this variance could be explained by differences in pressure ulcer prevention.

Design. A cross-sectional questionnaire survey nested in a prospective multicenter cohort study.

Method. A questionnaire was distributed to nursing staff employed in 10 Dutch nursing homes $(n=600)$ and 11 German nursing homes ( $n=578$ ). Data were collected in January 2009.

Results. The response rate was $75.7 \%$ in the Netherlands $(n=454)$ and $48.4 \%$ in Germany ( $n=283$ ). Knowledge about useful pressure ulcer preventive measures was moderate in both countries, while non-useful preventive measures were poorly known. On average only $19.2 \%$ (the Netherlands) and $24.6 \%$ (Germany) of preventive measures were judged correctly as non-useful. The same pattern could be seen with regard to the use of preventive measures, because non-useful preventive measures were still commonly used according to the respondents.

Conclusions. The results indicate that the respondents' knowledge and use of pressure ulcer preventive measures could be improved in both countries, especially for non-useful measures. Changes and improvements can be achieved by providing sufficient education and refresher courses for nurses and nursing assistants employed within Dutch and German nursing homes.

Relevance to clinical practice. Recurring education about pressure ulcer prevention is required among nursing staff employed in Dutch and German nursing homes, particularly in relation to the use of ineffective and outdated preventive measures. Obstacles regarding the implementation of preventive measures should be addressed to achieve a change in practice. 


\section{INTRODUCTION}

Within the nursing home sector, pressure ulcers are still a frequent occurring and serious healthcare problem. ${ }^{1-3}$ The National pressure ulcer advisory panel and European pressure ulcer advisory panel (2009) define a pressure ulcer as 'a localized injury to the skin and/or underlying tissue usually over a bony prominence, as a result of pressure, or pressure in combination with shear'. ${ }^{4}$ Pressure ulcer prevalence rates in nursing homes range internationally from $7.9 \%-83.6 \%$. $^{2,5,6}$

Both nationally and internationally, pressure ulcer guidelines have been developed over the past few years to prevent and treat pressure ulcers in a systematic way. ${ }^{4,7-9}$ Correct application of guidelines is presumed to have various benefits, such as an improved quality and efficiency of patient care. ${ }^{10,11}$ To change clinical practice, guidelines must be disseminated and implemented in clinical practice. Unfortunately, many studies have recognised that proper implementation of guidelines is often not achieved. ${ }^{12-17} \mathrm{Grol}$ and Grimshaw (2003) showed in their study that $30-40 \%$ of patients do not receive care according to current scientific evidence. ${ }^{18}$ Moreover, $20 \%$ or more of the provided care is not needed or may be potentially harmful.

\section{BACKGROUND}

In the Netherlands (NL) and Germany (GER), national pressure ulcer prevalence surveys have been carried out annually since 1998 (NL) and 2001 (GER). Both countries use the same standard definitions, instruments and methodology. ${ }^{5,19}$ Results of these surveys demonstrate a great discrepancy in prevalence rates between both countries. This is most evident for the nursing home sector, with reported rates over 3 times higher in Dutch nursing homes (30.8\%) equated to the German ones (8.3\%). ${ }^{20}$ Tannen et al. (2008) investigated this disparity and concluded that some of the discrepancy could be explained by differences in nursing practices aimed at pressure ulcer prevention. ${ }^{21}$

In the Netherlands, the first national pressure ulcer guideline was formulated in 1985 and revised in 1992 and 2002.,22,23 In Germany, the 'National German Expert Standard for the prevention of pressure ulcers' was developed in 2000 and updated in 2004. ${ }^{24,25}$

Several studies have demonstrated that nurses have a positive attitude with regard to pressure ulcer prevention. ${ }^{26,27}$ Nevertheless, numerous studies have revealed shortcomings in the implementation of pressure ulcer guidelines in daily practice. ${ }^{26,28,29}$ Hulsenboom et al. (2007) investigated the knowledge among Dutch hospital nurses. They concluded that Dutch hospital nurses' knowledge about pressure ulcer prevention was moderate. ${ }^{30} \mathrm{~A}$ recent study conducted in Dutch nursing homes revealed that useful preventive measures were not used in all cases and nurses' knowledge of pressure ulcer guideline recommendations was lacking. ${ }^{26}$ Although knowledge among nursing staff is in itself not enough to insure implementation of guideline recommendations, it is a 
prerequisite, along with other factors like insight, attitude and skills, for the implementation process. ${ }^{31-33}$

The aim of the study was to examine the gap between theory and practice regarding pressure ulcer prevention in more depth by exploring nursing staff's knowledge about pressure ulcer preventive strategies and nursing staff's preventive practice in nursing homes in the Netherlands and Germany. Moreover, this study aimed to compare the findings for nursing staff in the Netherlands and Germany.

\section{METHODS}

\section{Design}

This study was a cross-sectional survey, nested in a prospective multicenter cohort study. $^{34}$

\section{Participants}

One or more wards from 10 nursing homes in the Netherlands and 11 nursing homes in Germany participated in the study. ${ }^{34}$ The database of the national prevalence measurement of care problems (LPZ) 2008 was used to select the nursing homes in the Netherlands. ${ }^{35}$ Pressure ulcer prevalence rates from $53 \%$ of all Dutch nursing homes are obtainable through the LPZ database. The German nursing homes were selected via the government database. Nursing homes situated in the regions Limburg or Brabant (the Netherlands) or Berlin and Brandenburg (Germany) were selected for participation in the study. Nursing homes that met the inclusion criteria were all entered into SPSS version 17 and the 'select cases' option was used to randomly choose 10 Dutch and 11 German nursing homes for study participation. In the Netherlands, 119 nursing homes met the inclusion criteria. In the first stage, eight of the 10 selected nursing homes and in the second stage, two of the four selected nursing homes were willing to take part in the study. In Germany, 288 nursing homes met the inclusion criteria. In the first stage, six of the 10 selected nursing homes were willing to take part in the study; in the second stage one, in the third stage two and in the fourth stage two of the eight selected nursing homes were willing to take part in the study.

\section{Data collection}

Data were collected using a questionnaire. The first part of the questionnaire contained demographic characteristics about the respondents, such as age, gender and position. For country comparison, we applied the position classification from Simoens et al. (2005); registered nurses, practical nurses and nurse aides. ${ }^{36}$ For the second part of the questionnaire, we used the 2003 Pressure Ulcer Questionnaire (PUQ-2003) developed by Hulsenboom et al. (2007) to assess nursing staff's knowledge and use of pressure ulcer 
preventive measures. ${ }^{30}$ This questionnaire is based on the Dutch national pressure ulcer guideline, developed in 2002. ${ }^{7}$ The guideline includes 29 pressure ulcer preventive measures which are divided into two sections. The first section comprises 16 measures that are useful to prevent pressure ulcers for patients at risk of pressure ulcer development, such as ensuring good hygiene. The second section encloses 13 measures that are not useful to prevent pressure ulcers, such as using warm compresses.

The PUQ-2003 includes two parts. The first part requires the respondents to evaluate the usefulness of the preventive measures for patients who have a high risk of pressure ulcer development. Answering options for each measure were 'useful', 'sometimes useful', 'not useful' or 'don't know'. The second part asks the respondents to judge their practice in terms of preventive measures applied in their ward/department for all high risk patients (always), preventive measures applied only for individual high risk patients (sometimes) or preventive measures which are never applied (never). Tables 6.2-6.5 give an overview of the included measures. The PUQ-2003 was translated into German. The content of the questionnaire was validated by the German investigators by face validity. The preventive measures, both recommended and non-recommended, corresponded also with the German Expert Standard for Pressure Ulcer Prevention. ${ }^{25}$

Data were collected over a 4-week period in January 2009. Nursing staff from the participating wards within the Dutch and German nursing homes were asked to participate voluntarily. Nursing staff included registered nurses, practical nurses, and nurse aides. ${ }^{36}$ The questionnaires were distributed and collected by research assistants working on the different sites. Together with the questionnaires the respondents received an information sheet and reply envelope. Completed questionnaires had to be returned within a 3-week period. The research assistants returned the filled-in questionnaires to the researchers in both countries (EM; DW).

\section{Ethical considerations}

Ethical approval was obtained from the relevant ethical committees in both countries. Potential participants were given an information sheet which included elaborated information about the study objective. Study participation was voluntary and anonymous. Completion of the questionnaire was considered to be consent.

\section{Data analysis}

Descriptive statistics were used to analyse the sample characteristics. The analysis comprised age, educational level and work experience in the area of nursing care. Furthermore, a descriptive analysis of the frequencies was performed for the questions about knowledge and use. To compare the knowledge and use between the two countries, the answers were recoded as 'judged correctly' and 'judged incorrectly'. Measures were judged correctly if the recommendation in the guideline corresponded with the judgment of the respondent. Differences between both countries in knowledge and use of each measure were examined by chi-square tests. Analyses of variance were 
used to compare the Netherlands and Germany on the mean ratings computed for both knowledge (useful and not useful) and use (useful and not useful). Predictive Analytics SoftWare (PASW) version 17 from SPSS was used to analyse the data. All tests used a twosided significance level of .05.

\section{Validity and reliability}

The original Dutch version of the questionnaire was developed and tested in previous Dutch studies among hospital nurses. ${ }^{30,37}$ Construct validity was tested by means of principal factor analyses. . $^{30,37}$ The Dutch questionnaire was translated into English by a professional translator. The English version was translated into German by two authors and back-translated to Dutch. The Dutch and German versions were cross-checked and unclear items were discussed within the research group. The German national pressure ulcer guideline was used for the correct German terminology. ${ }^{25}$

\section{RESULTS}

\section{Response rate}

The questionnaires were sent to 600 nurses and nursing assistants in the Netherlands and 578 nurses and nursing assistants in Germany. In total, 454 (NL) and 283 (GER) questionnaires were returned, indicating a response rate of $75.7 \%$ in the Netherlands and $48.4 \%$ in Germany. Four of the German questionnaires were not filled in; therefore 279 of the German questionnaires were used for further analysis. The response rates per nursing home ranged from $52.6 \%$ to $90.2 \%$ in the Netherlands and $22.8 \%$ to $90.5 \%$ in Germany.

\section{Sample characteristics}

The majority of respondents in both countries were female $(92.5 \%$ in the Netherlands and $80.6 \%$ in Germany). The Dutch respondents ranged in age from 18-61 years (mean age: 36.3 years), while the German respondents ranged in age from 18-64 years (mean age: 38.6 years). The Dutch sample had the largest number of respondents with 11-25 years and more than 25 years of working experience. The Dutch respondents had also been employed for longer within the nursing home. There was also a difference in nursing staff positions; the German sample included significantly more registered nurses and practical nurses while the Dutch sample included significantly more nurse aides. Moreover, in the Dutch sample, more respondents had followed refresher courses in the area of pressure ulcer care compared to the German sample. Participant characteristics are summarized in Table 6.1. 
Table 6.1 Sample characteristics (\%).

\begin{tabular}{lccc}
\hline & $\begin{array}{c}\text { the Netherlands } \\
(\mathrm{n}=454)\end{array}$ & $\begin{array}{c}\text { Germany } \\
(\mathrm{n}=279)\end{array}$ & -values \\
\hline Female & 92.5 & 80.6 & $<0.001$ \\
Age & & & 0.88 \\
18-25 years & 14.8 & 14.7 & \\
$26-35$ years & 25.1 & 26.2 & \\
$36-45$ years & 28.2 & 25.1 & \\
46-55 years & 23.8 & 26.5 & $<0.001$ \\
$56-65$ years & 4.8 & 7.5 & \\
Position & & & \\
Registered nurse & 8.4 & 17.7 & $<0.001$ \\
Practical nurse & 34.6 & 45.1 & \\
$\quad$ Nurse aide & 57.0 & 37.2 & \\
Refresher course pressure ulcer care & 85.9 & 52.7 & \\
Working experience & & & \\
$<1$ year & 0.9 & 5.1 & \\
$1-3$ years & 10.4 & 19.2 & $<0.001$ \\
$4-10$ years & 31.4 & 35.1 & \\
$11-25$ years & 42.0 & 34.1 & \\
$>25$ years & 15.3 & 6.5 & \\
Employed in nursing home & & & \\
$<1$ year & 5.3 & 24.0 & \\
$1-3$ years & 21.4 & 37.2 & \\
$4-10$ years & 36.8 & 25.2 & \\
$11-25$ years & 29.7 & 12.8 & \\
$>25$ years & 6.4 & 0.8 & \\
\hline
\end{tabular}

\section{Knowledge of useful pressure ulcer preventive measures}

The respondents' knowledge of useful pressure ulcer preventive measures is summarized in Table 6.2. The results show that knowledge of useful preventive measures is generally good. The respondents judged on average $71.3 \%$ (the Netherlands) and $66.3 \%$ (Germany) of the preventive measures correctly as useful, showing a significant difference between the two countries.

Measures indicated by most respondents as useful were 'ensuring good hygiene', 'ensuring a clean, dry layer of bedclothes', 'preventing shear forces' and 'assessing the nutritional state'. On the other hand, some measures were poorly known among the respondents in both countries, such as 'using visco-elastic mattresses'. For some measures large differences in knowledge could be seen between the two countries, whereas significantly more Dutch respondents answered that the measures 'preventing skin maceration', 'using air mattresses', and 'smearing the skin to prevent dehydration' are useful pressure ulcer preventive measures compared with the German respondents.

Another deviation between the two countries could be seen for the respondents who did not give the correct answer. Whereas most Dutch respondents chose for the answer possibility 'sometimes', most German respondents answered 'not useful' or 'don't know'. 
Table 6.2 Respondents' knowledge of useful pressure ulcer preventive measures.

\begin{tabular}{|c|c|c|c|c|c|c|c|c|c|}
\hline & \multicolumn{4}{|c|}{ the Netherlands } & \multicolumn{4}{|c|}{ Germany } & \multirow[t]{2}{*}{$p_{\text {-values }}{ }^{b}$} \\
\hline & $\begin{array}{l}\text { Use } \\
\text { ful }\end{array}$ & $\begin{array}{l}\text { Some } \\
\text { times }\end{array}$ & $\begin{array}{c}\text { Not } \\
\text { useful }\end{array}$ & $\begin{array}{l}\text { Don't } \\
\text { know }\end{array}$ & $\begin{array}{l}\text { Use } \\
\text { ful }\end{array}$ & $\begin{array}{l}\text { Some } \\
\text { times }\end{array}$ & $\begin{array}{c}\text { Not } \\
\text { useful }\end{array}$ & $\begin{array}{l}\text { Don't } \\
\text { know }\end{array}$ & \\
\hline $\begin{array}{l}\text { Involving patients in } \\
\text { prevention }\end{array}$ & 59.8 & 34.9 & 4.9 & 0.4 & 79.3 & 19.6 & 0.4 & 0.7 & $<0.001$ \\
\hline $\begin{array}{l}\text { Assessing risk by means of an } \\
\text { instrument and clinical } \\
\text { judgment }\end{array}$ & 80.2 & 16.0 & 1.3 & 2.4 & 93.4 & 4.8 & 0.7 & 1.1 & $<0.001$ \\
\hline $\begin{array}{l}\text { Using visco-elastic (foam) } \\
\text { mattresses and pillows }\end{array}$ & 25.7 & 37.6 & 4.7 & 32.0 & 27.9 & 44.2 & 9.1 & 18.9 & 0.521 \\
\hline Ensuring good hygiene & 99.1 & 0.9 & $-{ }^{a}$ & $-{ }^{a}$ & 97.4 & 1.8 & 0.4 & 0.4 & 0.072 \\
\hline $\begin{array}{l}\text { Preventing maceration of the } \\
\text { skin }\end{array}$ & 80.3 & 13.9 & 0.9 & 4.9 & 10.4 & 32.2 & 39.0 & 18.6 & $<0.001$ \\
\hline $\begin{array}{l}\text { Using a } 30 \text {-degree side to side } \\
\text { turn every } 4 \text { hours }\end{array}$ & 64.9 & 30.0 & 2.7 & 2.4 & 77.1 & 21.8 & 0.4 & 0.7 & 0.001 \\
\hline $\begin{array}{l}\text { Ensuring a clean, dry and } \\
\text { square lower layer of } \\
\text { bedclothes }\end{array}$ & 95.1 & 4.0 & 0.2 & 0.7 & 93.7 & 1.9 & 3.0 & 1.5 & 0.419 \\
\hline $\begin{array}{l}\text { Smearing the skin with topical } \\
\text { agents in case of urine- and/or } \\
\text { faeces incontinence }\end{array}$ & 73.8 & 21.6 & 4.2 & 0.4 & 73.1 & 20.9 & 3.7 & 2.2 & 0.850 \\
\hline $\begin{array}{l}\text { Using air mattresses and } \\
\text { pillows }\end{array}$ & 66.7 & 30.4 & 0.4 & 2.5 & 20.0 & 42.2 & 21.9 & 15.9 & $<0.001$ \\
\hline $\begin{array}{l}\text { Smearing the skin with topical } \\
\text { agents to prevent dehydration }\end{array}$ & 64.6 & 28.1 & 4.5 & 2.9 & 48.8 & 35.8 & 11.9 & 4.5 & $<0.001$ \\
\hline Preventing shear forces & 86.4 & 10.3 & 0.7 & 2.7 & 93.3 & 3.7 & 1.1 & 1.9 & 0.004 \\
\hline $\begin{array}{l}\text { Involving } \\
\text { family/friends/caregivers in } \\
\text { prevention }\end{array}$ & 61.9 & 32.4 & 4.3 & 1.4 & 70.1 & 25.8 & 1.8 & 2.2 & 0.026 \\
\hline $\begin{array}{l}\text { Helping non-bedridden } \\
\text { patients lift up or assume a } \\
\text { different position }\end{array}$ & 63.2 & 32.1 & 2.5 & 2.2 & 63.8 & 29.1 & 3.7 & 3.4 & 0.864 \\
\hline $\begin{array}{l}\text { Avoiding contact of the heels } \\
\text { with lower layer by putting a } \\
\text { pillow under lower legs }\end{array}$ & 57.3 & 37.6 & 3.1 & 2.0 & 66.4 & 29.2 & 3.0 & 1.5 & 0.016 \\
\hline Daily inspection of the skin & 82.4 & 14.5 & 1.3 & 1.8 & 89.3 & 7.0 & 1.1 & 2.6 & 0.013 \\
\hline $\begin{array}{l}\text { Assessing nutritional state and } \\
\text { preventing nutritional } \\
\text { deficiency }\end{array}$ & 89.8 & 9.4 & 0.9 & $--^{a}$ & 94.1 & 5.2 & $--^{a}$ & 0.7 & 0.046 \\
\hline $\begin{array}{l}\text { Mean number of measures } \\
\text { judged correctly }\end{array}$ & \multicolumn{4}{|c|}{11.4 of $16(71.3 \%)$} & \multicolumn{4}{|c|}{10.6 of $16(66.3 \%)$} & 0.001 \\
\hline$\sigma$ and range & \multicolumn{4}{|c|}{$2.9 ; 0-16$} & \multicolumn{4}{|c|}{$3.0 ; 0-16$} & \\
\hline
\end{tabular}

a -- indicates that none of the respondents gave this answer; ${ }^{b} \mathrm{p}$-values for means refer to the results of analyses of variance and those for percents refer to $\chi^{2}$ tests.

\section{Knowledge of non-useful pressure ulcer preventive measures}

The respondents' knowledge of measures which are not of use in preventing pressure ulcers is summarised in Table 6.3. Results show that non-useful preventive measures were poorly known among the respondents in both countries. On average, only $19.2 \%$ (the 
Netherlands) and 24.6\% (Germany) of the preventive measures were judged correctly as non-useful, indicating a significant difference between the two countries. Non-useful measures that were frequently answered as useful in both countries are 'smearing the skin to prevent blood supply disturbance caused by pressure', 'reactivation and mobilization by paramedics' and 'massage'.

A deviation between the two countries could be seen for the answer 'don't know', while for all measures more Dutch respondents gave this answer.

Table 6.3 Respondents' knowledge of non-useful pressure ulcer preventive measures.

\begin{tabular}{|c|c|c|c|c|c|c|c|c|c|}
\hline & \multicolumn{4}{|c|}{ the Netherlands } & \multicolumn{4}{|c|}{ Germany } & \multirow[t]{2}{*}{$p$-values ${ }^{a}$} \\
\hline & $\begin{array}{l}\text { Use } \\
\text { ful }\end{array}$ & $\begin{array}{l}\text { Some- } \\
\text { times }\end{array}$ & $\begin{array}{c}\text { Not } \\
\text { useful }\end{array}$ & $\begin{array}{l}\text { Don't } \\
\text { know }\end{array}$ & Use ful & $\begin{array}{l}\text { Some- } \\
\text { times }\end{array}$ & $\begin{array}{c}\text { Not } \\
\text { useful }\end{array}$ & $\begin{array}{l}\text { Don't } \\
\text { know }\end{array}$ & \\
\hline Using a sheepskin & 5.6 & 45.4 & 35.9 & 13.1 & 9.2 & 22.9 & 53.4 & 14.5 & $<0.001$ \\
\hline $\begin{array}{l}\text { Using a 90-degree side to } \\
\text { side turn at least every } 4 \\
\text { hours }\end{array}$ & 43.1 & 38.9 & 13.1 & 4.9 & 33.8 & 42.0 & 20.8 & 3.3 & 0.006 \\
\hline Massage & 34.7 & 42.4 & 18.9 & 4.0 & 57.3 & 36.7 & 3.7 & 2.2 & $<0.001$ \\
\hline $\begin{array}{l}\text { Avoiding contact of heels } \\
\text { with lower layer by using } \\
\text { ring shaped cushions or } \\
\text { gloves filled with water } \\
\text { (donuts) }\end{array}$ & 13.2 & 32.9 & 25.1 & 28.9 & 14.9 & 27.5 & 47.2 & 10.4 & $<0.001$ \\
\hline $\begin{array}{l}\text { Reactivation and } \\
\text { mobilization by paramedics }\end{array}$ & 78.0 & 20.3 & 1.3 & 0.4 & 81.0 & 16.7 & 1.1 & 1.1 & 0.797 \\
\hline Using warm compresses & 4.0 & 19.9 & 46.1 & 30.0 & 4.1 & 19.7 & 59.1 & 17.1 & 0.001 \\
\hline Using a cradle & 18.6 & 72.9 & 4.0 & 4.5 & 26.7 & 50.8 & 14.3 & 8.3 & $<0.001$ \\
\hline $\begin{array}{l}\text { Using water mattresses and } \\
\text { pillows }\end{array}$ & 24.6 & 37.7 & 12.1 & 25.7 & 16.2 & 39.5 & 27.4 & 16.9 & $<0.001$ \\
\hline Using ice compresses & 2.5 & 19.7 & 32.6 & 45.2 & 1.9 & 14.9 & 62.8 & 20.3 & $<0.001$ \\
\hline $\begin{array}{l}\text { Wrapping the heels/elbows } \\
\text { in natural cotton wool and } \\
\text { bandages }\end{array}$ & 12.9 & 36.2 & 30.1 & 20.8 & 54.2 & 35.1 & 9.6 & 1.1 & 0.001 \\
\hline $\begin{array}{l}\text { Using gel mattresses and } \\
\text { pillows }\end{array}$ & 36.3 & 43.0 & 7.6 & 13.1 & 49.3 & 42.2 & 4.5 & 4.1 & 0.102 \\
\hline $\begin{array}{l}\text { Inserting a catheter to } \\
\text { prevent maceration of the } \\
\text { skin }\end{array}$ & 10.7 & 58.5 & 14.3 & 16.5 & 14.4 & 43.6 & 28.0 & 14.0 & $<0.001$ \\
\hline $\begin{array}{l}\text { Smearing the skin (with } \\
\text { topical agents) to prevent } \\
\text { disturbance in blood supply } \\
\text { caused by pressure }\end{array}$ & 52.4 & 31.3 & 8.9 & 7.3 & 77.9 & 19.2 & 2.2 & 0.7 & 0.001 \\
\hline $\begin{array}{l}\text { Mean number of measures } \\
\text { judged correctly }\end{array}$ & \multicolumn{4}{|c|}{2.5 of $13(19.2 \%)$} & \multicolumn{4}{|c|}{3.2 of $13(24.6 \%)$} & 0.001 \\
\hline$\sigma$ and range & \multicolumn{4}{|c|}{$2.5 ; 0-10$} & \multicolumn{4}{|c|}{$2.2 ; 0-8$} & \\
\hline
\end{tabular}

${ }^{a} p$-values for means refer to the results of analyses of variance and those for percents refer to $\chi^{2}$ tests. 


\section{Use of useful pressure ulcer preventive measures}

Table 6.4 summarises the results of the use of useful pressure ulcer preventive measures. The answers show that the respondents used on average $68.1 \%$ (the Netherlands) and 63.1\% (Germany) of the preventive measures correctly, showing a significant difference between the two countries. For some measures, large differences in use could be seen between the two countries, whereas significantly more Dutch respondents used the measures 'preventing maceration of the skin' and 'using air mattresses and pillows' correctly compared to the German respondents. On the other hand, more German respondents used a risk assessment scale.

Table 6.4 Respondents' use of useful pressure ulcer preventive measures.

\begin{tabular}{|c|c|c|c|c|c|c|c|}
\hline & \multicolumn{3}{|c|}{ the Netherlands } & \multicolumn{3}{|c|}{ Germany } & \multirow[t]{2}{*}{$p$-values ${ }^{b}$} \\
\hline & Always & $\begin{array}{l}\text { Some- } \\
\text { times }\end{array}$ & Never & Always & $\begin{array}{l}\text { Some- } \\
\text { times }\end{array}$ & Never & \\
\hline Involving patients in prevention & 72.3 & 0.2 & 27.4 & 71.7 & 27.6 & 0.7 & 0.849 \\
\hline $\begin{array}{l}\text { Assessing risk by means of an } \\
\text { instrument and clinical judgment }\end{array}$ & 65.9 & $--^{a}$ & 34.1 & 90.7 & 9.3 & $--^{a}$ & $<0.001$ \\
\hline \multicolumn{8}{|l|}{ mattresses and pillows } \\
\hline Ensuring good hygiene & 98.2 & $--^{a}$ & 1.8 & 95.2 & 4.8 & $--^{a}$ & 0.034 \\
\hline Preventing maceration of the skin & 74.1 & 2.8 & 23.1 & 10.0 & 35.5 & 54.4 & $<0.001$ \\
\hline $\begin{array}{l}\text { Using a } 30 \text {-degree side to side turn } \\
\text { at least every } 4 \text { hours }\end{array}$ & 51.1 & $--^{a}$ & 48.9 & 58.1 & 39.7 & 2.2 & 0.069 \\
\hline $\begin{array}{l}\text { Ensuring a clean, dry and square } \\
\text { lower layer of bedclothes }\end{array}$ & 91.3 & 2.9 & 5.8 & 96.0 & 3.3 & 0.7 & 0.212 \\
\hline $\begin{array}{l}\text { Smearing the skin with topical } \\
\text { agents in case of urine- and/or } \\
\text { faeces incontinence }\end{array}$ & 65.5 & 1.4 & 33.1 & 65.5 & 30.3 & 4.1 & 0.758 \\
\hline Using air mattresses and pillows & 67.8 & 0.2 & 32.0 & 13.3 & 26.1 & 60.6 & $<0.001$ \\
\hline $\begin{array}{l}\text { Smearing the skin with topical } \\
\text { agents to prevent dehydration }\end{array}$ & 59.1 & 0.2 & 40.7 & 66.9 & 30.5 & 2.6 & 0.036 \\
\hline Preventing shear forces & 80.4 & $--^{a}$ & 19.6 & 93.0 & 5.5 & 1.5 & $<0.001$ \\
\hline $\begin{array}{l}\text { Involving family/friends/caregivers } \\
\text { in prevention }\end{array}$ & 72.7 & 0.2 & 27.1 & 68.4 & 29.8 & 1.8 & 0.212 \\
\hline $\begin{array}{l}\text { Helping non-bedridden patients } \\
\text { lift up or assume a different } \\
\text { position }\end{array}$ & 62.5 & $--^{a}$ & 37.5 & 51.7 & 44.6 & 3.7 & 0.004 \\
\hline $\begin{array}{l}\text { Avoiding contact of the heels with } \\
\text { lower layer by putting a pillow } \\
\text { under the lower legs }\end{array}$ & 48.6 & 0.3 & 51.1 & 58.1 & 38.6 & 3.4 & 0.015 \\
\hline Daily inspection of the skin & 81.0 & 1.6 & 17.4 & 83.0 & 15.6 & 1.5 & 0.545 \\
\hline $\begin{array}{l}\text { Assessing nutritional state and } \\
\text { preventing nutritional deficiency }\end{array}$ & 83.4 & 16.2 & 0.4 & 95.6 & 3.7 & 0.7 & $<0.001$ \\
\hline $\begin{array}{l}\text { Mean number of measures judged } \\
\text { correctly }\end{array}$ & \multicolumn{3}{|c|}{10.9 of $16(68.1 \%)$} & \multicolumn{3}{|c|}{10.1 of $16(63.1 \%)$} & $<0.001$ \\
\hline$\sigma$ and range & \multicolumn{3}{|c|}{$2.8 ; 0-16$} & \multicolumn{3}{|c|}{$3.2 ; 0-16$} & \\
\hline
\end{tabular}

a -- indicates that none of the respondents gave this answer; ${ }^{b} p$-values for means refer to the results of analyses of variance and those for percents refer to $\chi^{2}$ tests. 
Another deviation between the two countries could be seen for the incorrect use of preventive measures. Whereas most Dutch respondents chose for the answer possibility 'never', most German respondents answered 'sometimes'.

\section{Use of non-useful pressure ulcer preventive measures}

The results of the use of non-useful pressure ulcer preventive measures are summarised in Table 6.5. Non-useful preventive measures are still frequently applied in practice according to the respondents in both countries, as only $34.6 \%$ (the Netherlands) and $32.3 \%$ (Germany) of the preventive measures were used correctly. Although these rates are comparable, the proportion of Dutch respondents who used these non-useful measures 'always' is much higher for almost all measures compared to the German respondents who mostly use these measures 'sometimes'.

Clear differences for individual measures could be seen for the measures 'massage' and 'wrapping the heels in natural cotton wool'. More Dutch respondents answered that they 'never' used these measures, while for the measures 'use of a cradle' and 'using a sheepskin', more German respondents gave this answer.

Table 6.5 Respondents' use of non-useful pressure ulcer preventive measures.

\begin{tabular}{|c|c|c|c|c|c|c|c|}
\hline & \multicolumn{3}{|c|}{ the Netherlands } & \multicolumn{3}{|c|}{ Germany } & \multirow[t]{2}{*}{$p$-values ${ }^{b}$} \\
\hline & Always & $\begin{array}{l}\text { Some } \\
\text { times }\end{array}$ & Never & Always & $\begin{array}{l}\text { Some } \\
\text { Times }\end{array}$ & Never & \\
\hline Using a sheepskin & 54.1 & 0.5 & 45.3 & 6.2 & 33.2 & 60.6 & $<0.001$ \\
\hline $\begin{array}{l}\text { Using a } 90 \text {-degree side to side turn at } \\
\text { least every } 4 \text { hours }\end{array}$ & 85.7 & $--^{a}$ & 14.3 & 20.5 & 46.4 & 25.1 & $<0.001$ \\
\hline Massage & 78.7 & 0.2 & 21.1 & 43.1 & 51.7 & 5.2 & $<0.001$ \\
\hline $\begin{array}{l}\text { Avoiding contact of heels with lower } \\
\text { layer by using ring shaped cushions or } \\
\text { gloves filled with water (donuts) }\end{array}$ & 47.9 & 0.7 & 51.4 & 14.4 & 33.1 & 52.5 & 0.790 \\
\hline $\begin{array}{l}\text { Reactivation and mobilization by } \\
\text { paramedics }\end{array}$ & 98.2 & 0.7 & 1.1 & 67.0 & 32.6 & 0.4 & 0.203 \\
\hline Using warm compresses & 28.0 & 0.4 & 71.6 & 6.0 & 24.3 & 69.8 & 0.612 \\
\hline Using a cradle & 7.1 & 84.7 & 8.2 & 19.8 & 55.5 & 24.7 & $<0.001$ \\
\hline Using water mattresses and pillows & 65.0 & $--^{a}$ & 35.0 & 13.7 & 47.3 & 38.9 & 0.287 \\
\hline Using ice compresses & 31.7 & 2.1 & 66.2 & 3.4 & 21.0 & 75.6 & 0.009 \\
\hline $\begin{array}{l}\text { Wrapping the heels/elbows in natural } \\
\text { cotton wool and bandages }\end{array}$ & 51.9 & 0.9 & 47.2 & 51.5 & 42.2 & 6.3 & $<0.001$ \\
\hline Using gel mattresses and pillows & 88.4 & 0.8 & 10.8 & 36.4 & 58.7 & 4.4 & 0.004 \\
\hline $\begin{array}{l}\text { Inserting a catheter to prevent } \\
\text { maceration of the skin }\end{array}$ & 74.8 & $--^{a}$ & 25.2 & 10.9 & 51.3 & 37.7 & $<0.001$ \\
\hline $\begin{array}{l}\text { Smearing the skin (with topical agents) } \\
\text { to prevent disturbance in blood supply } \\
\text { caused by pressure }\end{array}$ & 86.2 & 1.0 & 12.8 & 38.7 & 49.6 & 11.7 & 0.667 \\
\hline $\begin{array}{l}\text { Mean number of measures used } \\
\text { correctly }\end{array}$ & \multicolumn{3}{|c|}{4.5 of $13(34.6 \%)$} & \multicolumn{3}{|c|}{4.2 of $13(32.3 \%)$} & 0.158 \\
\hline$\sigma$ and range & \multicolumn{3}{|c|}{$2.9 ; 0-12$} & \multicolumn{3}{|c|}{$2.6 ; 0-12$} & \\
\hline
\end{tabular}




\section{DISCUSSION}

Limitations of the study include the difference in response rate between the Netherlands and Germany. Although the same instruments and procedures were used in both countries, the response rate in the Netherlands was higher. However, dissimilarity in response rate was mainly caused by a low response rate in two of the German nursing homes.

A second limitation concerns the data about nurses' reported use of preventive measures. The use of preventive measures was self-reported, no external observers were involved. This could have influenced the responses, and respondents might have given socially desired answers. So the distance between actual clinical practice and reported practice could have been even bigger than recognised by our study. However, due to the disparity in answers obtained and the fact that the majority of the respondents had a low level of agreement with the guideline recommendations, we presume that there is no significant difference between actual clinical practice and the results obtained.

\section{Knowledge}

The results revealed that nurses and nursing assistants' knowledge about useful preventive measures was moderate in both countries. The mean knowledge score for useful preventive measures was $71.3 \%$ in the Netherlands and $66.3 \%$ in Germany. Low scores were found for the use of visco-elastic mattresses. Furthermore, the German sample scored poor for the prevention of skin maceration. The Dutch sample scored low for the involvement of patients, 59.8\%. In other studies these rates varied from $1 \%{ }^{38}$ till 98.4\%. ${ }^{39}$

The knowledge score for non-useful preventive measures was $19.2 \%$ in the Netherlands and $24.6 \%$ in Germany. These results indicate that a knowledge deficit about non-useful preventive measures was present in both countries. Unsuitable measures still deemed to be appropriate by a large amount of the respondents in both countries include: massage, the use of doughnut-type devices and the use of a catheter. Poor knowledge about these measures was also found by several other authors. ${ }^{30,39-41}$

When combining the knowledge scores of both useful and non-useful measures, the overall knowledge score was $47.7 \%$ in the Netherlands and $47.5 \%$ in Germany. These figures are comparable with those found in other studies: $50 \%{ }^{40}, 49.6 \%{ }^{42}$, but may be contrasted with other studies: $79.1 \%{ }^{41}, 73.6 \%{ }^{39}$ and $29.0 \% .{ }^{43}$

Adequate knowledge about pressure ulcer preventive strategies is important, as it underpins decision-making related to which patients require interventions and which pressure ulcer preventive intervention should be applied. Of course, knowledge alone is not enough, because nursing staff must actually apply the knowledge they have. Therefore, this study also examined nurses' reported use of preventive measures in relation to pressure ulcer prevention. 


\section{Practice}

In general, the level of knowledge was reflected in the reported practice. Where respondents had a good knowledge score on useful measures, these were also frequently used in practice. Regretfully, poor knowledge about non useful measures was also translated into practice. A large number of respondents, in both countries, reported that outdated and inefficient (sometimes harmful) interventions, for instance massage, the use of doughnut-type devices, ice compresses and sheepskin, were still frequently used in clinical practice. Comparison between both countries indicated that the Dutch respondents answered that they mainly used these measures 'always', whereas the German respondents used these measures mostly 'sometimes'.

In this study, massage was used by a large proportion of respondents: $78.9 \%$ in the Netherlands and $94.8 \%$ in Germany. These figures may be compared with those acquired by other studies: $35.5 \%{ }^{41}, 31.4 \%{ }^{40}$ The use of doughnut-type devices has also been identified by other studies. ${ }^{40,41,44}$

Overall, our results reveal that further effort is still required to improve knowledge about pressure ulcer preventive measures among nursing staff in nursing homes in the Netherlands and Germany. Improved knowledge may lead to better use of guidelines in clinical practice. One way to improve knowledge is by providing sufficient education. The importance of education has been well demonstrated. ${ }^{45-47}$ Education raises awareness of the problem and provides the information needed to carry out prevention effectively. ${ }^{48}$ This study concluded that outdated measures were still frequently used. Educational programmes should clarify why these measures are inefficient, so that nursing staff stop believing in them. ${ }^{41}$ However, education alone will be of limited value if it is not reflected in clinical practice. Successful prevention depends also on the attitudes of nursing staff. ${ }^{27,49,50}$ A negative attitude can lead to nonapplication of preventive measures in clinical practice. ${ }^{29,47}$ Maylor and Torrance (1999) showed that the more prevention is valued, the more likely it will be carried out. ${ }^{51}$ Moreover, the use of guideline recommendations in practice can be influenced by barriers to their use in clinical practice. Frequently reported barriers include a lack of staff, lack of time, lack of knowledge or skills, lack of cooperation by residents, insufficient cooperation from other professionals, and lack of motivation. ${ }^{12,26,27}$ Addressing these barriers is essential to obtain a good level of implementation of pressure ulcer preventive measures.

\section{CONCLUSION}

This study revealed that nursing staffs' knowledge about pressure ulcer preventive measures could be improved in both countries, especially for the non-useful measures. It is especially alarming that preventive measures proven to be harmful, such as the use of ice compresses and doughnut-type devices, were still frequently used. An improvement of nurses' knowledge regarding pressure ulcer prevention is needed; more attention to the 
Chapter 6

knowledge of non-useful preventive measures may also improve the nonapplication of these measures. Providing sufficient education, a positive attitude and addressing barriers are all important aspects to improve knowledge and use of pressure ulcer preventive measures among nursing staff.

\section{RELEVANCE TO CLINICAL PRACTICE}

Recurring education about pressure ulcer prevention is required among nursing staff employed in Dutch and German nursing homes, particularly in relation to the use of ineffective and outdated preventive measures. Obstacles with regard to the implementation of pressure ulcer preventive measures should be recognised and addressed to achieve a change in practice. 


\section{REFERENCES}

1. De Souza DM, De Gouveia Santos VL (2010) Incidence of pressure ulcers in the institutionalized elderly. Journal of Wound, Ostomy and Continence Nursing 2010;37:272-276.

2. Halfens R, Meesterberends E, Meijers JJM, Du Moulin MFMT, van Nie NC, Neyens JCL, Schols JMGA. Rapportage resultaten: Landelijke Prevalentiemeting Zorgproblemen 2011. Maastricht: Maastricht University; 2011.

3. Vanderwee K, Clark M, Dealey C, Gunningberg L, Defloor T. Pressure ulcer prevalence in Europe: a pilot study. Journal of Evaluation in Clinical Practice 2007;13:227-235.

4. National Pressure Ulcer Advisory Panel and European Pressure Ulcer Advisory Panel. Prevention and treatment of pressure ulcers: clinical practice guideline. Washington DC: National Pressure Ulcer Advisory Panel; 2009.

5. Bours GJJW, Halfens RJG, Lubbers M, Haalboom JRE. The development of a national registration form to measure the prevalence of pressure ulcers in the Netherlands. Ostomy Wound Management 1999;45:28-40.

6. Landi F, Russo A, Danese P, Liperoti R, Barillaro C, Bernabei R, Onder G. Anemia status, hemoglobin concentration, and mortality in nursing home older residents. Journal of the American Medical Directors Association 2007;8:322-327.

7. Centraal Begeleidingsorgaan voor de Intercollegiale Toetsing. Decubitus. Tweede herziening. Alphen aan den Rijn: Van Zuiden; 2002.

8. National Institute for Health and Clinical Excellence. Pressure ulcers: the management of pressure ulcers in primary and secondary care. London: National Institute for Health and Clinical Excellence; 2005.

9. Registered Nurses Association of Ontario. Risk assessment \& prevention of pressure ulcers. Toronto: Registered Nurses Association of Ontario; 2005.

10. Ayello E, Sibbald R. Preventing pressure ulcers and skin tears. In: Capezuti E, Zwicker D, Mezey M, Fulmer T, eds. Evidence-based Geriatric Nursing Protocols for Best Practice. 3rd ed. New York: Springer Publishing Company; 2008, 403-429.

11. Registered Nurses Association of Ontario. Assessment and management of stage I to IV pressure ulcers. Toronto: Registered Nurses Association of Ontario; 2007.

12. Clark M. Barriers to the implementation of clinical guidelines. Journal of Tissue Viability 2003;13:62-72.

13. Gunningberg L. Risk, prevalence and prevention of pressure ulcers in three Swedish health-care settings. Journal of Wound Care 2004;13:286-290.

14. Moore Z. Pressure ulcer prevention: nurses' knowledge, attitudes and behaviour. Journal of Wound Care 2004;13:330-334.

15. Gunningberg L, Lindholm C, Carlsson M, Sjöden PO. Risk, prevention and treatment of pressure ulcers: nursing staff knowledge and documentation. Scandinavian Journal of Caring Sciences 2001;15:257-263.

16. Paquay L, Wouters R, Defloor T, Buntinx F, Debaillie R, Geys L. Adherence to pressure ulcer prevention guidelines in home care: a survey of current practice. Journal of Clinical Nursing 2008;17:627-636.

17. Parahoo K. Barriers to, and facilitators of, research utilization among nurses in Northern Ireland. Journal of Advanced Nursing 2000;31:89-98.

18. Grol R, Grimshaw J. From best evidence to best practice: effective implementation of change in patients' care. The Lancet 2003;362:1225-1230.

19. Dassen T, Petermann B, Heinze C, Lahmann N, Lohrmann C, Mertens E, Tannen A. Dekubitus, Sturzereignisse, Pflegeabhängigkeit: Prävalenzerhebung 2002. Berlin: Institut für Medizin/Pflegepädagogik und Pflegewissenschaft; 2002. 
20. Tannen A, Dietz E, Dassen T, Halfens R. Explaining the national differences in pressure ulcer prevalence between the Netherlands and Germany: adjusted for personal risk factors and institutional quality indicators. Journal of Evaluation in Clinical Practice 2009;15:85-90.

21. Tannen A, Dassen T, Halfens R. Differences in prevalence of pressure ulcers between the Netherlands and Germany: associations between risk, prevention and occurrence of pressure ulcers in hospitals and nursing homes. Journal of Clinical Nursing 2008;17:1237-1244.

22. Centraal Begeleidingsorgaan voor de Intercollegiale Toetsing. Consensus preventie van decubitus. Utrecht: Centraal Begeleidingsorgaan voor de Intercollegiale Toetsing; 1985.

23. Centraal Begeleidingsorgaan voor de Intercollegiale Toetsing. Herziening consensus decubitus. Utrecht: Centraal Begeleidingsorgaan voor de Intercollegiale Toetsing; 1992.

24. Deutsches Netzwerk für Qualitätsentwicklung in der Pflege. Expertenstandard 'Dekubitusprophylaxe in der Pflege' Entwicklung - Konsentierung 1. Auflage. Osnabrück: Deutsches Netzwerk für Qualitätsentwicklung in der Pflege; 2000.

25. Deutsches Netzwerk für Qualitätsentwicklung in der Pflege. Expertenstandard Dekubitusprophylaxe in der Pflege. Entwicklung - Konsentierung - Implementierung 2. Auflage mit aktualisierter Literaturstudie (1999-2002). 2nd ed. Osnabrück: Deutsches Netzwerk für Qualitätsentwicklung in der Pflege; 2004.

26. Meesterberends E, Halfens RJ, Lohrmann C, Schols JM, De Wit R. Evaluation of the dissemination and implementation of pressure ulcer guidelines in Dutch nursing homes. Journal of Evaluation in Clinical Practice 2011;17:705-712.

27. Moore Z, Price P. Nurses' attitudes, behaviours and perceived barriers towards pressure ulcer prevention. Journal of Clinical Nursing 2004;13:942-951.

28. Bours GJJW, Halfens RJG, Huijer Abu-Saad H, Grol RTPM. Prevalence, prevention and treatment of pressure ulcers: descriptive study in 89 institutions in the Netherlands. Research in Nursing \& Health 2002;25:99-110.

29. Buss IC, Halfens RJG, Huijer Abu-Saad H, Kok G. Pressure ulcer prevention in nursing homes: views and beliefs of enrolled nurses and other health care workers. Journal of Clinical Nursing 2004;13:668-676.

30. Hulsenboom MA, Bours GJ, Halfens RJ. Knowledge of pressure ulcer prevention: a crosssectional and comparative study among nurses. BMC Nursing 2007;6.

31. Wensing M, Van der Weijden T, Grol R. Implementing guidelines and innovations in general practice: which interventions are effective? British Journal of General Practice 1998;48: 991-997.

32. Rogers EM. Diffusion of innovations, 5th edition. New York: The Free Press; 2003

33. Grol R, Wensing M. What drives change? Barriers to and incentives for achieving evidencebased practice. Medical Journal of Australia 2004;180:S57-S60.

34. Meesterberends E, Halfens RJ, Heinze C, Lohrmann C, Schols JM. Pressure ulcer incidence in Dutch and German nursing homes: design of a prospective multicenter cohort study. BMC Nursing 2011;10.

35. Halfens RJG, Meijers JMM, Neyens JCL, Offermans MPW. Rapportage resultaten: Landelijke Prevalentiemeting Zorgproblemen 2008. Maastricht: Universiteit Maastricht; 2008.

36. Simoens S, Villeneuve M, Hurst J. Tackling nurse shortages in OECD countries. Paris; 2005.

37. Halfens RJG, Eggink M. Knowledge, beliefs and use of nursing methods in preventing pressure sores in Dutch hospitals. International Journal of Nursing Studies 1995;32:16-26.

38. Saliba D, Rubenstein LV, Simon B, Hickey E, Ferrell B, Czarnowski E, Berlowitz D. Adherence to pressure ulcer prevention guidelines: implications for nursing home quality. Journal of the American Geriatrics Society 2003;51:56-62.

39. Miyazaki MY, Caliri MH, Santos CB. Knowledge on pressure ulcer prevention among nursing professionals. Revista Latino-Americana de Enfermagem 2011;18:1203-1211. 
40. Panagiotopoulou K, Kerr SM. Pressure area care: an exploration of Greek nurses' knowledge and practice. Journal of Advanced Nursing 2002;40:285-296.

41. Pancorbo-Hidalgo PL, Garcia-Fernandez FP, Lopez-Medina IM, Lopez-Ortega J. Pressure ulcer care in Spain: nurses' knowledge and clinical practice. Journal of Advanced Nursing 2007; 58:327-338.

42. Beeckman D, Defloor T, Schoonhoven L, Vanderwee K. Knowledge and attitudes of nurses on pressure ulcer prevention: a cross-sectional multicenter study in Belgian hospitals. Worldviews on Evidence-Based Nursing 2011;8:166-176.

43. Demarré L, Vanderwee K, Defloor T, Verhaeghe S, Schoonhoven L, Beeckman D. Pressure ulcers: knowledge and attitude of nurses and nursing assistants in Belgian nursing homes. Journal of Clinical Nursing 2012;21:1425-1434.

44. Sharp C, Burr G, Broadbent M, Cummins M, Casey H, Merriman A. Pressure ulcer prevention and care: a survey of current practice. Journal of Quality in Clinical Practice 2000;20:150-157.

45. Maylor ME. Knowledge base and use in the management of pressure sores. Journal of Wound Care 1997;6:244-247.

46. Arblaster G. Pressure sore incidence: a strategy for reduction. Nursing Standard 1998;12:49-52.

47. Källman U, Suserud BO. Knowledge, attitudes and practice among nursing staff concerning pressure ulcer prevention and treatment: a survey in a Swedish healthcare setting. Scandinavian Journal of Caring Sciences 2009;23:334-341.

48. Benbow M. Keeping the pressure off. Nursing the Elderly 1992;4:17-19.

49. Anthony DM. The formation of pressure sores and the role of nursing care. Journal of Wound Care 1996;5:192-194.

50. Land L. A review of pressure damage prevention. Journal of Advanced Nursing 1995;22: 329-337.

51. Maylor M, Torrance C. Pressure sore survey. Part 3: Locus of control. Journal of Wound Care 1999;8:101-105. 


\section{CHAPTER}

DO PATIENTS IN DUTCH NURSING HOMES HAVE MORE PRESSURE ULCERS THAN PATIENTS IN GERMAN NURSING HOMES? A PROSPECTICE MULTICENTER COHORT STUDY

Esther Meesterberends, Ruud J.G. Halfens, Marieke D. Spreeuwenberg, Ton A.W. Ambergen, Christa Lohrmann, Jacques C.L. Neyens, Jos M.G.A. Schols Journal of the American Medical Directors Association 2013;14:605-610 


\section{ABSTRACT}

Objectives. To investigate whether the incidence of pressure ulcers in nursing homes in the Netherlands and Germany differs and, if so, to identify resident-related risk factors, nursing-related interventions and structural factors associated with pressure ulcer development in nursing home residents.

Design. A prospective multicenter cohort study.

Setting. Ten nursing homes in the Netherlands and 11 nursing homes in Germany (around Berlin and Brandenburg).

Participants. A total of 547 newly admitted nursing home residents, of which 240 were Dutch and 307 were German. Residents had an expected length of stay of 12 weeks or longer.

Measurements. Data were collected for each resident over a 12-week period and included resident characteristics (eg, demographics, medical history, Braden scale scores, nutritional factors), pressure ulcer prevention and treatment characteristics, staffing ratios and other structural nursing home characteristics, and outcome (pressure ulcer development during the study). Data were obtained by trained research assistants.

Results. A significantly higher pressure ulcer incidence rate was found for the Dutch nursing homes (33.3\%) compared to the German nursing homes (14.3\%). Six factors that explain the difference in pressure ulcer incidence rates were identified: dementia, analgesics use, the use of transfer aids, repositioning the residents, the availability of a tissue viability nurse on the ward, and regular internal quality controls in the nursing home.

Conclusion. The pressure ulcer incidence was significantly higher in Dutch nursing homes than in German nursing homes. Factors related to residents, nursing care and structure explain this difference in incidence rates. Continuous attention to pressure ulcer care is important for all health care settings and countries, but Dutch nursing homes especially should pay more attention to repositioning residents, the necessity and correct use of transfer aids, the necessity of analgesics use, the tasks of the tissue viability nurse and the performance of regular internal quality controls. 


\section{INTRODUCTION}

Pressure ulcer prevalence rates are considered to be a good indicator of quality of care. ${ }^{1-4}$ Within the nursing home sector, pressure ulcers remain a large and relevant care problem..$^{5-7}$ Studies worldwide have reported a great disparity in pressure ulcer prevalence rates in these settings, ranging from $7.7 \%$ to $83.6 \% .^{5,7-10}$ Results from annual national pressure ulcer prevalence surveys in health care institutions in the Netherlands and Germany, which use the same standardized definitions, instruments and methodology, 8,11 have also revealed large differences in prevalence rates between the countries over the past 10 years, especially in nursing homes. ${ }^{12,13}$ Rates in Dutch nursing homes (30.8\%) have been reported to be more than 3 times as high as those in German nursing homes (8.3\%). ${ }^{13}$ The exact reasons for these differences are still unknown. However, various studies have identified patient-related risk factors such as age, limited mobility and activity levels, diabetes mellitus, malnutrition and urinary and fecal incontinence. ${ }^{14-18}$ Furthermore, nursing-related interventions, such as failure to reposition residents ${ }^{19}$ are also linked to the development of pressure ulcers. Besides these more process-oriented factors, structural factors (related to the health care organization itself), such as staffing levels and staff education may also play a role in the occurrence of pressure ulcers. ${ }^{20,21}$

This study was designed to investigate whether the incidence of pressure ulcers in nursing homes in the Netherlands and Germany differs, and, if so, to identify resident-related risk factors, nursing-related interventions and structural factors associated with pressure ulcer development in nursing home residents.

\section{METHODS}

\section{Study design and ethics}

This prospective cohort study was carried out in 10 nursing homes in the Netherlands and 11 nursing homes in Germany between August 2009 and September 2011. The participating nursing homes in the Netherlands were selected through the 2008 Dutch National Prevalence Measurement of Care Problems database. ${ }^{22}$ In Germany, nursing homes were selected through the government database for the federal states of Berlin and Brandenburg. Nursing homes that met the inclusion criteria (capacity of more than 50 beds and located in the regions Limburg or Brabant, the Netherlands, or Berlin and Brandenburg, Germany) were entered into SPSS version 17 (SPSS Inc, Chicago, IL), and subsequently 10 Dutch and 11 German nursing homes were chosen at random by using the "select cases" option.

The study included newly admitted residents who were followed for 12 weeks. Residents were excluded from participation if they had an expected nursing home stay of less than 3 months, if they had been diagnosed with a terminal illness, or if their informed consent was received later than 3 weeks after their admission to the nursing home. In the Dutch 
population, there were 435 new admissions during the inclusion period, of which 27 $(6,2 \%)$ did not meet the inclusion criteria and 168 refused to participate $(38,6 \%)$. In total 240 Dutch residents participated in the study. In the German population there were 553 new admissions during the study period, of which $37(6,7 \%)$ did not meet the inclusion criteria and $209(37,8 \%)$ refused to participate. In total, 307 German residents participated in the study. A detailed report of the study design and methodology was published elsewhere. $^{23}$

The medical ethical committees of the Maastricht University Medical Hospital and CharitéUniversitätsmedizin Berlin granted full ethical approval for this study. The privacy of the participating residents was protected and all data were coded and processed anonymously.

\section{Measurements}

Data were collected using resident-specific, nursing-home-specific and ward-specific questionnaires. Most questions were adapted from the questionnaires of the Dutch National Prevalence Measurement of Care Problems, ${ }^{22}$ which are based on information gathered from literature reviews and a Delphi panel of pressure ulcer care experts. The reliability and validity of these questionnaires have been proven in earlier research. ${ }^{8}$

All questionnaires are described in the following paragraphs. Further information about the data collection instrument and study methodology can be found elsewhere. ${ }^{23}$

\section{Resident-specific questionnaire}

Research assistants completed a weekly resident-specific questionnaire for each participating resident. This questionnaire contained questions about demographics, medical history, use of medication, pressure ulcer risk, mental status, existence of pressure ulcer(s) (yes/no), pressure ulcer category, repositioning and posture, mobilisation and transfer, skin care and skin inspection, use of pressure-relieving mattresses and cushions, nutritional fluid intake and prevention of malnutrition, and incontinence care. The resident's risk of developing a pressure ulcer was assessed by using the Braden scale. ${ }^{24,25}$ The existence of pressure ulcer(s) was assessed by physical examination carried out by trained research assistants. In addition to the resident questionnaire, the residents' care dependency was also assessed every 4 weeks by using the Care Dependency Scale (CDS). ${ }^{26,27}$

\section{Ward-and nursing home-specific questionnaires}

The ward-specific questionnaire contained questions about the type of ward, the number of residents and rooms on the ward, ward specialization, staffing patterns (educational qualifications and full-time equivalents), presence of pressure ulcer prevention and treatment guidelines, and whether there was a tissue viability nurse working on the ward. The nursing home-specific questionnaire included questions about the number of residents, the type of specialization, staffing patterns (educational qualifications and full- 
time equivalents), quality control (internal and external), the presence of a pressure ulcer committee, and the presence of pressure ulcer prevention and treatment guidelines.

\section{Data collection}

Research assistants were responsible for collecting the data from the nursing home residents. Data were obtained by speaking to the residents directly or, if not possible, by consulting a responsible nurse or nursing assistant and/or the resident documentation.

All research assistants were nurses who were educated and experienced in the area of pressure ulcer care. All had been trained and instructed by the research team to collect the data for this study. The research assistants were not employed by the participating nursing homes. The ward manager filled in the ward questionnaires and the nursing home manager filled in the nursing home questionnaires.

\section{Statistical analyses}

Descriptive statistics were used to calculate the item frequency, mean, standard deviation, median and range. Bivariate analyses, using cross-tabulation and chi-square tests for ordinal and nominal data, were performed to compare all resident, nursing care and structural characteristics between nursing homes in the Netherlands and Germany. Means were compared by using Student's $t$-tests. All factors with significant group differences of $P$ less than .10 were selected as possible exploratory factors for the difference in pressure ulcer incidence and were included in a Cox regression analysis. A univariate Cox proportional hazards regression analysis was performed to estimate the hazard ratio of country regarding the incidence of pressure ulcers. The dependent variable was the time to development of a pressure ulcer and the independent variable was "country". In the multivariate Cox regression analysis, all factors that were related to country difference (with a $P$ value smaller than 0.10 ), which can be found in Table 7.3, 7.4 and 7.5, were added to the model step by step so that the hazard ratio of country changed closer to 1 . Only covariates that led to a significant change (more than $10 \%$ of the hazard ratio) were included. The multivariate Cox regression analysis included the following time-dependent covariates: proper position, mobilisation, repositioning, measures for the prevention of malnutrition, and the use of a pressure-relieving mattress. The stepwise inclusion method was used to evaluate baseline and time-dependent changes in covariates or risk factors. Survival curves were calculated by the Kaplan-Meier method. All statistical analyses were performed using SPSS version 18 (SPSS Inc, Chicago, IL, USA). 


\section{RESULTS}

\section{Response rate}

In total, 547 newly admitted residents participated in the study, of which 240 were in Dutch and 307 in German nursing homes. During the 12-week follow-up period, 98 residents (14 in the Netherlands and 84 in Germany) dropped out of the study, creating an overall dropout rate of $17.9 \%$ (5.8\% in the Netherlands and $27.4 \%$ in Germany). Residents dropped out of the study because they passed away, were discharged from the nursing home, were admitted to the hospital, refused further participation, or for other, unknown reasons.

\section{Characteristics of the residents}

Table 7.1 gives an overview of the baseline characteristics of the residents in both countries. The German residents were significantly older than the Dutch residents: 84.8 years versus 80.5 years. Most of the residents in both countries were female. Significantly more residents in Germany (35.5\%) were admitted from the hospital compared with the Netherlands (25.4\%). More Dutch residents used a walking aid or were confined to a wheelchair. Use of medication was higher for the Dutch residents. Furthermore, the risk of developing a pressure ulcer (measured by the Braden scale) was higher for the Dutch residents. More German residents suffered from urinary incontinence (69.9\%) than Dutch residents $(47.5 \%)$.

\section{Pressure ulcer development}

Table 7.2 provides an overview of the residents who already had a pressure ulcer when they entered the study and residents who developed a pressure ulcer during the study. Significantly more German residents had an existing pressure ulcer when they entered the study: $15.3 \%$ versus $5.0 \%$ of the Dutch residents. Contrary, significantly more Dutch residents developed a pressure ulcer during the study: $33.3 \%$ versus $14.3 \%$ of the German residents. Of these $12.1 \%$ versus $6.5 \%$ were category 1 pressure ulcers, $12.9 \%$ versus $4.2 \%$ were category 2 pressure ulcers, $5.0 \%$ versus $2.6 \%$ were category 3 pressure ulcers and $3.3 \%$ versus $1.0 \%$ were category 4 pressure ulcers. Figure 7.1 gives an overview of the proportion of residents who were pressure ulcer-free versus the time spent in the nursing home. 
Table 7.1 Characteristics of the residents, given as $\mathrm{n}(\%)$ or Mean \pm SD (range).

\begin{tabular}{|c|c|c|c|}
\hline & the Netherlands $(n=240)$ & Germany $(n=307)$ & $P$ Value \\
\hline Age & $80.5 \pm 8.6(63-100)$ & $84.8 \pm 8.2(67-102)$ & $<0.001^{*}$ \\
\hline Female & $154(64.2)$ & $213(69.4)$ & 0.198 \\
\hline Body mass index & $24.2 \pm 4.6(14.3-42.8)$ & $23.9 \pm 5.0(13.6-48.1)$ & 0.449 \\
\hline \multicolumn{4}{|l|}{ Living situation before nursing home } \\
\hline Home & 91 (37.9) & 107 (34.9) & 0.459 \\
\hline Other nursing home & $56(23.3)$ & $56(18.2)$ & 0.143 \\
\hline Hospital & $61(25.4)$ & $109(35.5)$ & $0.011^{*}$ \\
\hline Other & $27(11.3)$ & $21(6.8)$ & $0.070^{*}$ \\
\hline \multicolumn{4}{|l|}{ Operation } \\
\hline $\begin{array}{l}\text { (in the past } 3 \text { months before nursing } \\
\text { home admission) }\end{array}$ & $32(13.3)$ & $51(20.0)$ & $0.047^{*}$ \\
\hline \multicolumn{4}{|l|}{ Supporting aids } \\
\hline Glasses & $174(72.5)$ & $175(57.0)$ & $<0.001^{*}$ \\
\hline Reading glasses & $44(18.3)$ & $85(27.7)$ & $0.011^{*}$ \\
\hline Hearing aid & $48(20.0)$ & $53(17.3)$ & 0.413 \\
\hline Wheelchair & $108(45.0)$ & $106(34.5)$ & $0.013^{*}$ \\
\hline Walking aid & $109(45.4)$ & $105(34.2)$ & $0.008^{*}$ \\
\hline False teeth & $168(70.0)$ & $205(66.8)$ & 0.422 \\
\hline Medication use & $6.7 \pm 3.2(0-16)$ & $6.0 \pm 2.9(0-17)$ & $0.008^{*}$ \\
\hline Braden scale score & $17.4 \pm 3.2(8-23)$ & $18.1 \pm 3.8(7-23)$ & $0.028^{*}$ \\
\hline Sensory perception & 3.3 & 3.5 & $<0.001^{*}$ \\
\hline Moisture & 3.1 & 3.3 & $0.013^{*}$ \\
\hline Activity & 2.9 & 2.8 & 0.473 \\
\hline Mobility & 2.7 & 2.9 & $0.016^{*}$ \\
\hline Nutrition & 3.1 & 3.3 & 0.116 \\
\hline Friction and shear & 2.3 & 2.3 & 0.511 \\
\hline \multicolumn{4}{|l|}{ Clinical impression of cognition } \\
\hline Alert & $96(40.0)$ & $82(47.1)$ & 0.148 \\
\hline Mild disorientation & $104(43.3)$ & $47(27.0)$ & $0.001^{*}$ \\
\hline Moderate disorientation & $39(16.3)$ & $37(21.3)$ & 0.193 \\
\hline Severe disorientation & $1(0.4)$ & $7(4.0)$ & $0.009^{*}$ \\
\hline Comatose & $0(0.0)$ & $1(0.6)$ & 0.240 \\
\hline Feces incontinence & $90(37.5)$ & $121(39.8)$ & 0.584 \\
\hline Urinary incontinence & $114(47.5)$ & 214 (69.9) & $<0.001^{*}$ \\
\hline
\end{tabular}

*Significant.

Table 7.2 Pressure ulcer existence and development, n (\%).

\begin{tabular}{|c|c|c|c|c|}
\hline \multirow{2}{*}{\multicolumn{2}{|c|}{$\begin{array}{l}\text { Developed a pressure ulcer during } \\
\text { the study? }\end{array}$}} & \multicolumn{3}{|c|}{ Existing pressure ulcer at the beginning of the study? } \\
\hline & & Yes & No & Total \\
\hline \multirow[t]{2}{*}{ Yes } & the Netherlands & $7(2.9$ & $73(30.4)$ & $80(33.3)$ \\
\hline & Germany & $12(3.9)$ & $32(10.4)$ & $44(14.3)$ \\
\hline \multirow[t]{2}{*}{ No } & the Netherlands & $5(2.1)$ & $155(64.6)$ & $160(66.7)$ \\
\hline & Germany & $35(11.4)$ & $228(74.3)$ & $263(85.7)$ \\
\hline \multirow[t]{2}{*}{ Total } & the Netherlands & $12(5.0)$ & $228(95.0)$ & $240(100.0)$ \\
\hline & Germany & $47(15.3)$ & $260(84.7)$ & $307(100.0)$ \\
\hline
\end{tabular}




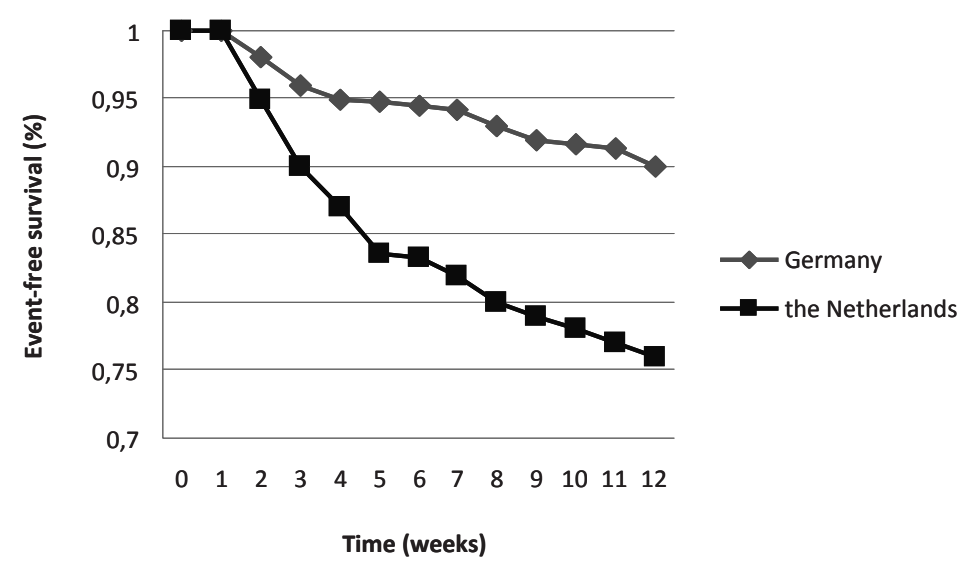

Figure 7.1 Proportion pressure ulcer-free versus time for the Netherlands and Germany.

\section{Bivariate analysis}

Bivariate analysis showed that significant differences existed between the two countries for resident-related, nursing-related, and structural factors. Tables 7.3-7.5 give an overview of the factors for which significant differences were found.

\section{Cox regression analysis}

The univariate Cox proportional hazards regression analysis revealed a hazard ratio for country of 0.388 for German residents versus Dutch residents. For the multivariate Cox regression analysis, all variables described in Tables 7.3, 7.4 and 7.5 were added to the model (with only country as independent variable) one by one separately. For each variable, the effect on the hazard ratio of country was examined. The factor that led to the largest change in hazard ratio of country to 1 was added to the final model (in our study, this was 'use of transfer aids'). Subsequently, all the other variables described in Tables 7.3, 7.4, and 7.5 (excluding 'use of transfer aids') were again added to the model with 'country' and 'use of transfer aids' one by one separately and again the factor that led to the largest change in hazard ratio of country was added to the final model (in our study this was 'tissue viability nurse working on the ward'). Following this procedure, the other 4 factors shown in Table 7.6 were added to the final model. After adding the sixth factor ('dementia') no other factor led to a significant change of more than $10 \%$ of the hazard ratio of country. Summarizing, the multivariate Cox proportional hazards regression analysis identified 6 factors that changed the hazard ratio of country from 0.388 to 0.994 , meaning that these factors contributed to the difference in pressure ulcer incidence rates between nursing homes in the Netherlands and Germany. These factors included residentrelated, nursing-related, and structural factors, which are shown in Table 7.6. Three of 
these factors were more common in Dutch nursing homes: the necessity to use a transfer aid to reposition and/or transfer the resident, the availability of a tissue viability nurse working on the ward, and the use of analgesics. The occurrence of one or more of these factors resulted in a hazard ratio higher than 1 , meaning that they increased the chance of developing a pressure ulcer. The other 3 factors were more common in the German nursing homes: repositioning the resident, suffering from dementia, and regular internal quality control in the nursing home. The existence of one or more of these factors resulted in a hazard ratio lower than 1 , meaning that these factors decreased the chance of developing a pressure ulcer.

Table 7.3 Univariate analyses, resident characteristics (\%).

\begin{tabular}{|c|c|c|c|}
\hline Variable Name & $\begin{array}{l}\text { the Netherlands } \\
(n=240)\end{array}$ & $\begin{array}{l}\text { Germany } \\
(n=307)\end{array}$ & $P$ value \\
\hline Marital status: married & 36.3 & 23.8 & 0.001 \\
\hline Age, mean & 80.5 & 84.8 & $<0.001$ \\
\hline Hospital stay before nursing home admission & 25.4 & 35.5 & 0.011 \\
\hline Home care before nursing home admission & 12.5 & 22.5 & 0.003 \\
\hline Operation & 13.3 & 20.0 & 0.047 \\
\hline \multicolumn{4}{|l|}{ Supporting aids } \\
\hline Glasses & 72.5 & 57.0 & $<0.001$ \\
\hline Wheelchair & 45.0 & 34.5 & 0.013 \\
\hline Reading glasses & 18.3 & 27.7 & 0.011 \\
\hline Walking aid & 45.4 & 34.2 & 0.008 \\
\hline \multicolumn{4}{|l|}{ Diagnoses } \\
\hline Infectious disease & 0.8 & 4.9 & 0.007 \\
\hline Dementia & 40.3 & 54.8 & 0.048 \\
\hline Heart and vascular system disease & 66.3 & 81.4 & $<0.001$ \\
\hline Blood disease & 6.7 & 13.7 & 0.008 \\
\hline Endocrine, nutrition, or metabolic disease & 11.7 & 30.3 & $<0.001$ \\
\hline Depression & 5.8 & 11.4 & 0.024 \\
\hline Respiratory disease & 22.1 & 15.3 & 0.042 \\
\hline Kidney, urinary tract, genital organs disease & 30.4 & 45.3 & $<0.001$ \\
\hline Acute urinary tract infection & 0 & 7.2 & $<0.001$ \\
\hline Total amount of diagnoses, mean & 3.8 & 4.6 & $<0.001$ \\
\hline \multicolumn{4}{|l|}{ Medication } \\
\hline Sedatives & 28.3 & 6.5 & $<0.001$ \\
\hline Analgesics & 62.9 & 23.8 & $<0.001$ \\
\hline Neuroleptics & 22.5 & 14.7 & 0.018 \\
\hline Total amount of medications, mean & 6.7 & 6.0 & 0.008 \\
\hline Braden scale score, mean & 17.4 & 18.1 & 0.028 \\
\hline Clinical impression of cognition: Mild disorientation & 43.3 & 27.0 & 0.001 \\
\hline Clinical impression of cognition: Severe disorientation & 0.4 & 4.0 & 0.009 \\
\hline Urinary incontinence & 47.5 & 69.9 & $<0.001$ \\
\hline
\end{tabular}


Chapter 7

Table 7.4 Univariate analyses, nursing care factors (\%).

\begin{tabular}{|c|c|c|c|}
\hline Variable Name & the Netherlands & Germany & $P$ value \\
\hline $\begin{array}{l}\text { Knowledge about useful pressure ulcer preventive } \\
\text { measures, mean }\end{array}$ & 11.5 & 10.5 & $<0.001$ \\
\hline $\begin{array}{l}\text { Knowledge about not useful pressure ulcer preventive } \\
\text { measures, mean }\end{array}$ & 2.5 & 3.0 & $<0.001$ \\
\hline \multicolumn{4}{|l|}{ Repositioning } \\
\hline 30-degree tilted side lying position & 11.7 & 18.9 & 0.021 \\
\hline Back & 0.4 & 17.6 & $<0.001$ \\
\hline Other position & 0.4 & 7.8 & $<0.001$ \\
\hline Time schedule & 0.8 & 11.7 & $<0.001$ \\
\hline Mobilisation sitting & 96.7 & 78.4 & $<0.001$ \\
\hline Mobilisation walking & 96.7 & 53.0 & $<0.001$ \\
\hline \multicolumn{4}{|l|}{ Skin care } \\
\hline Use of water & 100.0 & 38.4 & $<0.001$ \\
\hline Use of soap & 30.8 & 64.2 & $<0.001$ \\
\hline Use of a $\mathrm{pH}$-neutral product & 10.4 & 22.8 & $<0.001$ \\
\hline $\begin{array}{l}\text { Use of a special pressure ulcer } \\
\text { prevention product }\end{array}$ & 10.4 & 3.3 & 0.001 \\
\hline Hydration/fluid protocol & 10.0 & 60.7 & $<0.001$ \\
\hline Transfer aids & 29.2 & 8.2 & $<0.001$ \\
\hline Proper position ${ }^{*}$ & 61.0 & 77.1 & $<0.001$ \\
\hline Mobilisation* & 96.7 & 77.1 & $<0.001$ \\
\hline Repositioning $^{*}$ & 19.6 & 47.0 & $<0.001$ \\
\hline Malnutrition preventive measures & 71.3 & 23.1 & $<0.001$ \\
\hline Pressure-relieving mattress ${ }^{*}$ & 43.3 & 63.6 & $<0.001$ \\
\hline
\end{tabular}

${ }^{*}$ Time-dependent variable.

Table 7.5 Univariate analyses, structural factors (\%).

\begin{tabular}{lccc}
\hline Variable Name & the Netherlands & Germany & $P$ value \\
\hline Physician(s) working in the nursing home & 68.8 & 3.3 & $<0.001$ \\
Physiotherapist(s) working in the nursing home & 68.8 & 10.4 & $<0.001$ \\
External quality control & 100.0 & 61.2 & $<0.001$ \\
Internal quality control & 61.7 & 100.0 & $<0.001$ \\
Tissue viability nurse working on the ward & 40.4 & 3.5 & $<0.001$ \\
Tissue viability nurse working in the nursing home & 67.9 & 42.1 & $<0.001$ \\
Pressure ulcer committee & 79.6 & 40.7 & $<0.001$ \\
Pressure ulcer treatment protocol on the ward & 100.0 & 59.3 & $<0.001$ \\
Pressure ulcer treatment protocol within the nursing & 100.0 & 62.5 & $<0.001$ \\
home & & & \\
\hline
\end{tabular}


Table 7.6 Factors identified by multivariate Cox proportional hazard regression analysis with forward stepwise procedure.

\begin{tabular}{lccc}
\hline Variables in the Equation & B & Significance & Hazard Ratio \\
\hline $\begin{array}{l}\text { Model: country as independent variable } \\
\quad \text { Country }\end{array}$ & -0.947 & 0.000 & 0.388 \\
Model: country and other covariates as independent variables & & & 0.994 \\
$\quad$ Country & -0.006 & 0.989 & 3.221 \\
Use of transfer aids & 1.170 & 0.000 & 1.964 \\
Tissue viability nurse working on the ward & 0.675 & 0.028 & 1.377 \\
Use of analgesics & 0.320 & 0.253 & 0.545 \\
Repositioning & -0.606 & 0.333 & 0.741 \\
Regular internal quality control & -0.300 & 0.390 & 0.781 \\
$\quad$ Dementia & -0.247 & 0.370 & \\
\hline
\end{tabular}

\section{DISCUSSION}

This study found a significantly higher pressure ulcer incidence in the Dutch nursing homes (33.3\%) compared with the German nursing homes (14.3\%). The Cox proportional hazards regression analysis identified 6 factors that led to a change of the hazard ratio of country from 0.388 to 0.994 . This means that, after correction for the 6 variables in the final model, there is no difference in pressure ulcer incidence between the two countries. Two of these factors were related to the nursing home residents: suffering from dementia and the use of analgesics. The use of analgesics was defined as "The resident takes prescribed analgesics on a daily basis according to his/her medical file". Two factors were related to the nursing care provided: the use of transfer aids and repositioning the residents. The use of a transfer aid was defined as "Is a transfer aid (such as a hoist) used by the nursing staff to reposition and/or transfer the resident in bed, from bed to chair, and vice versa?". Reposition was defined as "Has the resident been repositioned according to a time schedule during the past 24 hours?".

Finally, two factors were related to structural factors at the nursing home: the availability of a tissue viability nurse on the ward, and regular internal quality controls in the nursing home. The availability of a tissue viability nurse was defined as "Is there a tissue viability nurse working in the nursing home or on the nursing home ward?" Regular internal quality controls were defined as "Are internal quality controls carried out on a regular basis (e.g., by head nurses) to supervise the daily work of the nursing staff on the ward?"

Other studies investigating the incidence of category 1 to 4 pressure ulcers in nursing homes found rates varying from $2.2 \%$ to $39.4 \% .{ }^{5,6,28-31}$ Compared with these rates, the incidence rate in the Dutch nursing homes (33.3\%) in our study is rather high, whereas the incidence rate in the German nursing homes (14.3\%) is rather low. The same pattern can also be recognized when investigating the incidence per pressure ulcer category, whereas for all the 4 categories, the incidence rates were higher in the Dutch nursing homes. 
The percentage of residents who already had a pressure ulcer at the start of the study was much higher in Germany than in the Netherlands. This finding could be explained by the fact that in this study more German residents were admitted from the hospital. Several studies have identified a hospital residence before a nursing home admission as a risk factor for pressure ulcer development. ${ }^{32,33}$ Because previous studies found that having a pressure ulcer on admission is a risk factor for developing new pressure ulcers, ${ }^{34}$ one might expect that their incidence during the follow-up period would be even higher in the German nursing homes. However, most German residents with an existing pressure ulcer at the start of the study did not develop a new pressure ulcer.

Some factors that explain the difference in pressure ulcer incidence between the Dutch and German nursing homes have been identified by other studies. In this study, dementia was more common in the German nursing homes and was identified as a factor that decreased the chance of developing a pressure ulcer, whereas other studies identified it as a risk factor. ${ }^{35-37}$

The current study reports the use of analgesics as a factor that increases the chance of developing a pressure ulcer. One possible explanation could be that the use of analgesics may lead to altered pain perception and lower sensitivity for pressure and shear forces, which has been demonstrated by other studies. ${ }^{38-40}$ Therefore, the necessity of analgesics use should be given careful consideration. If analgesics use is still needed, these people should be monitored closely, because the altered pain perception makes them more prone to pressure ulcer development. The necessity of using a transfer aid to reposition and/or transfer a resident increased the chance for developing a pressure ulcer in our study. Other studies have also confirmed the use of positioning devices as a risk factor for pressure ulcer development. ${ }^{5} \mathrm{~A}$ possible reason for this might be that the residents who need to be repositioned by means of such a device are more immobile and therefore more prone to pressure ulcer development. Furthermore, the use of transfer aids may result in more pressure and shear forces on specific body parts and incorrect use of transfer aids may cause more shear forces and, at worst, even damage to the skin.

A surprising result was the fact that the availability of a tissue viability nurse on the ward, which was more common in the Dutch nursing homes, was identified as a factor that increased the resident's chance of developing a pressure ulcer. A possible explanation might be that the other nursing staff views these nurses as primarily responsible for pressure ulcer care on their ward. The rest of the nursing staff might therefore be less concerned with the prevention of pressure ulcers. ${ }^{13}$ Therefore, the tasks of a tissue viability nurse should be clarified. Their focus should be on informing and coaching the nursing staff to gain more knowledge and experience about pressure ulcer prevention and treatment and to incorporate pressure ulcer care in regular nursing care. Finally, this study found that performing regular internal quality controls decreased the chance of developing a pressure ulcer. A logical reason for this could be that more control leads to more alertness and dedication among nursing staff and, consequently, to a better quality of care and more attention paid to pressure ulcer prevention. 
This study had some limitations. First, the dropout rate was higher for the German nursing home residents, mainly because of more hospital admissions. Second, although we have included a wide variety of factors in this study, it is possible that other factors that were not included in this study could have altered the results.

Strength of this study was the prospective design with 12 repeated measurements; this design allows to make causal connections and to closely monitor the development of a pressure ulcer. Furthermore, the measurements were taken by trained research assistants who were not employed by the nursing homes, so as to achieve reliable and nonbiased results. Moreover, this study collected both data about the residents, the nursing care provided and structural factors in the nursing homes.

\section{CONCLUSION}

This study revealed a significantly higher pressure ulcer incidence in Dutch nursing homes than in German nursing homes. Six factors, including resident-related, nursing-related and structural factors, explained the difference in pressure ulcer incidence rates between nursing homes in the Netherlands and Germany. Continuous attention to pressure ulcer care is important for all health care settings and countries, but Dutch nursing homes especially should pay more attention to repositioning residents, the necessity and correct use of transfer aids, the necessity of analgesics use, the tasks of the tissue viability nurse, and the performance of regular internal quality controls. Paying more attention to these factors may help decrease the pressure ulcer incidence rate in Dutch nursing homes. 


\section{REFERENCES}

1. Lyder $\mathrm{CH}$. Pressure ulcer prevention and management. Journal of the American Medical Association 2003;289:223-226.

2. Abel RL, Warren K, Bean G, Gabbard B, Lyder CH, Bing M, McCauley C. Quality improvement in nursing homes in Texas: results from a pressure ulcer prevention project. Journal of the American Medical Directors Association 2005;6:181-188.

3. Sloss E, Solomon D, Shekelle P, Young RT, Saliba D, MacLean CH, Rubenstein LZ, Schnelle JF, Kamberg CJ, Wenger NS. Selecting target conditions for quality of care improvement in vulnerable older adults. Journal of the American Geriatrics Society 2000;48:363-369.

4. Saliba D, Solomon D, Rubenstein L, Young R, Schnelle J, Roth C, Wenger N. Feasibility of quality indicators for the management of geriatric syndromes in nursing home residents. Journal of the American Medical Directors Association 2004;5:310-319.

5. Horn SD, Bender SA, Ferguson ML, Smout RJ, Bergstrom N, Taler G, Cook AS, Sharkey SS, Voss $A C$. The national pressure ulcer long-term care study: pressure ulcer development in long-term care residents. Journal of the American Geriatrics Society 2004;52:359-367.

6. De Souza DM, De Gouveia Santos VL. Incidence of pressure ulcers in the institutionalized elderly. Journal of Wound, Ostomy and Continence Nursing 2010;37:272-276.

7. Halfens R, Meesterberends E, Meijers JJM, Du Moulin MFMT, van Nie NC, Neyens JCL, Schols JMGA. Rapportage resultaten: Landelijke Prevalentiemeting Zorgproblemen 2011. Maastricht: Maastricht University; 2011.

8. Bours GJJW, Halfens RJG, Lubbers M, Haalboom JRE. The development of a national registration form to measure the prevalence of pressure ulcers in the Netherlands. Ostomy Wound Management 1999;45:28-40.

9. Gunningberg L. Risk, prevalence and prevention of pressure ulcers in three Swedish health-care settings. Journal of Wound Care 2004;13:286-290.

10. Landi F, Russo A, Danese P, Liperoti R, Barillaro C, Bernabei R, Onder G. Anemia status, hemoglobin concentration, and mortality in nursing home older residents. Journal of the American Medical Directors Association 2007;8:322-327.

11. Dassen T, Petermann B, Heinze C, Lahmann N, Lohrmann C, Mertens E, Tannen A. Dekubitus, Sturzereignisse, Pflegeabhängigkeit: Prävalenzerhebung 2002. Berlin: Institut für Medizin/Pflegepädagogik und Pflegewissenschaft; 2002.

12. Tannen A, Dassen T, Halfens R. Differences in prevalence of pressure ulcers between the Netherlands and Germany: associations between risk, prevention and occurrence of pressure ulcers in hospitals and nursing homes. Journal of Clinical Nursing 2008;17:1237-1244.

13. Tannen A, Dietz E, Dassen T, Halfens R. Explaining the national differences in pressure ulcer prevalence between the Netherlands and Germany: adjusted for personal risk factors and institutional quality indicators. Journal of Evaluation in Clinical Practice 2009;15:85-90.

14. Shahin ES, Dassen T, Halfens RJ. Pressure ulcer prevalence in intensive care patients: a crosssectional study. Journal of Evaluation in Clinical Practice 2008;14:563-568.

15. Haleem S, Heinert G, Parker MJ. Pressure sores and hip fractures. Injury 2008;39:219-223.

16. Lindgren $\mathrm{M}$, Unosson $\mathrm{M}$, Fredrikson $\mathrm{M}$, Ek AC. Immobility: a major risk factor for development of pressure ulcers among adult hospitalized patients: a prospective study. Scandinavian Journal of Caring Sciences 2004;18:57-64.

17. VanGilder C, Macfarlane G, Meyer S, Lachenbruch C. Body Mass Index, weight, and pressure ulcer prevalence: an analysis of the 2006-2007 international pressure ulcer prevalence surveys. Journal of Nursing Care Quality 2009;24:127-135.

18. Achterberg WP, Frijters DH, Ribbe MW. Het vóórkomen van ulcera in verpleeghuizen. Tijdschrift voor Gerontologie en Geriatrie 2008;39:115-121. 
19. National Pressure Ulcer Advisory Panel and European Pressure Ulcer Advisory Panel. Prevention and treatment of pressure ulcers: clinical practice guideline. Washington DC: National Pressure Ulcer Advisory Panel; 2009.

20. Hickey EC, Young GJ, Parker VA, Czarnowski EJ, Saliba D, Berlowitz DR. The effects of changes in nursing home staffing on pressure ulcer rates. Journal of the American Medical Directors Association 2005;6:50-53.

21. Alexander GL. An analysis of nursing home quality measures and staffing. Quality Management in Health Care 2008;17:242-251.

22. Halfens RJG, Meijers JMM, Neyens JCL, Offermans MPW. Rapportage resultaten: Landelijke Prevalentiemeting Zorgproblemen 2008. Maastricht: Universiteit Maastricht; 2008.

23. Meesterberends E, Halfens RJ, Heinze C, Lohrmann C, Schols JM. Pressure ulcer incidence in Dutch and German nursing homes: design of a prospective multicenter cohort study. BMC Nursing 2011;10.

24. Bergstrom N, Braden BJ, Laguzza A, Holman V. The Braden scale for predicting pressure sore risk. Nursing Research 1987;36:205-210.

25. Braden BJ, Bergstrom N. Predictive validity of the Braden scale for pressure sore risk in a nursing home. Research in Nursing \& Health 1994;17:459-470.

26. Dijkstra A. Care dependency, an assessment instrument for use in long-term care facilities, PhD thesis. Groningen; 1998.

27. Dijkstra A, Buist G, Dassen $T$, van den Heuvel W. Het meten van zorgafhankelijkheid met de ZorgAfhankelijkheidsSchaal, Care Dependency Scale (CDS): een handleiding. Groningen; 1999.

28. Cuddigan J, Ayello EA, Sussman C, Baranoski S. Pressure ulcers in America: prevalence, incidence, and implications for the future. Reston VA: National Pressure Ulcer Advisory Panel; 2001.

29. Vanderwee K, Grypdonck MH, De Bacquer D, Defloor T. Effectiveness of turning with unequal time intervals on the incidence of pressure ulcer lesions. Journal of Advanced Nursing 2007;57:59-68.

30. Kwong EW, Pang SM, Aboo GH, Law SS. Pressure ulcer development in older residents in nursing homes: influencing factors. Journal of Advanced Nursing 2009;65:2608-2620.

31. Kwong EW, Lau AT, Lee RL, Kwan RY. A pressure ulcer prevention programme specially designed for nursing homes: does it work? Journal of Clinical Nursing 2011;20:2777-2786.

32. Spector WD, Fortinsky RH. Pressure ulcer prevalence in Ohio nursing homes: clinical and facility correlates. Journal of Aging and Health 1998;10:62-80.

33. Baumgarten M, Margolis D, Gruber-Baldini AL, Zimmerman S, German P, Hebel JR, Magaziner J. Pressure ulcers and the transition to long-term care. Advances in Skin \& Wound Care 2003; 16:299-304.

34. Bergquist-Beringer S, Gajewski BJ. Outcome and assessment information set data that predict pressure ulcer development in older adult home health patients. Advances in Skin \& Wound Care 2011;24:404-414.

35. Zulkowski K. MDS+ RAP items associated with pressure ulcer prevalence in newly institutionalized elderly: study I. Ostomy Wound Management 1998;44:40-53.

36. Horn SD, Bender SA, Bergstrom N, Cook AS, Ferguson ML, Rimmasch HL, Sharkey SS, Smout RJ, Taler GA, Voss AC. Description of the national pressure ulcer long-term care study. Journal of the American Geriatrics Society 2002;50:1816-1825.

37. Thomas DR. Prevention and management of pressure ulcers. Missouri Medicine 2007;104 52-57.

38. Allman RM. Pressure ulcer prevalence, incidence, risk factors, and impact. Clinics in Geriatric Medicine 1997;13:421-436. 


\section{Chapter 7}

39. Boyle M, Green M. Pressure sores in intensive care: defining their incidence and associated factors and assessing the utility of two pressure sore risk assessment tools. Australian Critical Care 2001;14:24-30.

40. Smith M. A comprehensive review of risk factors related to the development of pressure ulcers. Journal of Orthopaedic Nursing 2003;7:94-102. 


\section{CHAPTER 8}

GENERAL DISCUSSION 
Chapter 8 


\section{GENERAL DISCUSSION}

Pressure ulcers are a common and serious health care problem within the nursing home sector. $^{1-3}$ They cause a major burden in terms of patient suffering and frustration ${ }^{4,5}$ and can result in a decreased quality of life, an increased need for intensive nursing and medical care, an increased workload for healthcare workers and, as a consequence, increased healthcare costs. ${ }^{5-9}$ Annual pressure ulcer prevalence surveys conducted in the Netherlands since 1998 and in Germany since $2001^{10,11}$ have revealed large differences in prevalence rates between nursing homes in both countries over the past ten years. ${ }^{12-14}$ Prevalence rates have been reported to be over three times as high in Dutch nursing homes (30.8\%) compared to German ones (8.3\%). ${ }^{14}$ A full explanation for this difference has not been found yet, ${ }^{12-14}$ partly because of the cross-sectional design of the prevalence studies, which makes it impossible to draw causal relationships, and because the prevalence studies did not measure all relevant factors, such as staffing levels. This implies that there are still unanswered questions around this difference in prevalence rates between both countries. As part of this thesis, a conceptual model was developed as a guide to obtain a complete view of all factors that could possibly influence this difference.

The overall aim of this thesis is to investigate the differences in pressure ulcer care between nursing homes in the Netherlands and Germany by measuring the incidence of pressure ulcers and possible related factors with respect to the nursing home residents, the nursing care provided and attributes of the care setting, such as the availability and implementation of a pressure ulcer guideline. The specific aims of this thesis are:

1. To investigate the process of pressure ulcer guideline development and dissemination in six European countries.

2. To assess the process of pressure ulcer guideline implementation in Dutch and German nursing homes.

3. To assess nursing staff's knowledge about pressure ulcer preventive strategies and nursing staff's preventive practice in nursing homes in the Netherlands and Germany.

4. To investigate the incidence of pressure ulcers in nursing homes in the Netherlands and Germany.

5. To identify patient-related, nursing-related and structural factors associated with pressure ulcer development.

This final chapter summarises the main findings of the separate studies, as presented in Chapters 2 through to 7, followed by a reflection from a methodological and theoretical perspective. Finally, implications for clinical practice and future research will be presented. 


\section{MAIN FINDINGS}

The first study investigating the process of pressure ulcer guideline development and dissemination in England, Germany, Italy, the Netherlands, Portugal and Sweden revealed that Portugal was the only country without national pressure ulcer prevention and treatment guidelines. The strategies used in the other five countries to disseminate national pressure ulcer guidelines to nursing homes differed in terms of number and type. Strategies varied from distributing the guideline to individual institutions to presenting the guideline at conferences. Nevertheless, all national organisations used a multifaceted strategy, which some studies have recognised as a successful dissemination approach. ${ }^{15,16}$ However other studies have not necessarily found it more effective than single interventions. ${ }^{17}$ The dissemination barrier mentioned most often was lack of money.

After this international comparison, the further studies pointed out in this thesis focused on the situation regarding pressure ulcer care in the Netherlands and Germany. The studies investigating the process of pressure ulcer guideline dissemination and implementation in Dutch and German nursing homes revealed that all participating nursing homes in both countries had institutional pressure ulcer prevention and treatment guidelines and that the dissemination of the guidelines to the nursing staff was successful. Nevertheless, improvements were possible in implementing pressure ulcer guidelines in the daily practice at the Dutch and German nursing homes. The implementation barriers were related to a lack of (qualified) personnel, additional work load, a lack of motivation and poor communication. These findings are in line with previous studies. ${ }^{18,19}$ Furthermore, all studies referring to the comparison between the Netherlands and Germany presented in this thesis observed an insufficient level of knowledge regarding pressure ulcer guideline recommendations among Dutch as well as German nursing staff. Knowledge about useful pressure ulcer preventive measures was moderate in both countries, and non-useful preventive measures were poorly known. The same pattern could be seen with regard to the use of preventive measures, since non-useful preventive measures were still commonly used. Other studies confirm this lack of knowledge among nursing home staff, especially with regard to non-useful pressure ulcer measures. ${ }^{20-23}$

The results of the prospective multicenter cohort study showed a higher pressure ulcer incidence during the first 12 weeks after nursing home admission for the Dutch nursing homes (33.3\%) compared to the German nursing homes (14.3\%). These results confirm the findings from the previous prevalence surveys, which showed higher pressure ulcer prevalence rates in the Dutch nursing homes. Six factors were identified that explained the difference in pressure ulcer incidence rates between nursing homes in both countries. Three of these factors increased the chance of developing a pressure ulcer and were more common in Dutch nursing homes, namely the necessity to use a transfer aid to reposition the resident, the availability of a tissue viability nurse working on the ward and the use of analgesics. The other three factors decreased the chance of developing a pressure ulcer 
and were more common in the German nursing homes. These were repositioning the resident, the resident suffering from dementia and regular internal quality control in the nursing home.

\section{THEORETICAL CONSIDERATIONS}

The results of this thesis reveal several differences in pressure ulcer care between the Dutch and German nursing homes. As mentioned in the introduction of this thesis, Donabedian's structure-process-outcome model was used as the theoretical framework for the studies in this thesis. ${ }^{24}$ The three key concepts in the model (structure, process and outcome) each have an effect or direct influence on the next. ${ }^{25}$ The strengths of this model are that it allows for an evaluation of the effectiveness of a current process. Furthermore it mirrors the care provided in that it has a data input point of multiple factors possibly affecting a process, which in turn affects the outcome.

In this thesis, 'structure' refers to the countries' health care systems and the structural aspects related to the nursing homes, 'process' refers to nursing- and patient-related factors and 'outcome' is referred to as pressure ulcer incidence or prevalence.

Figure 8.1 gives an overview of the model. The following part discusses the findings of the thesis according to this model.

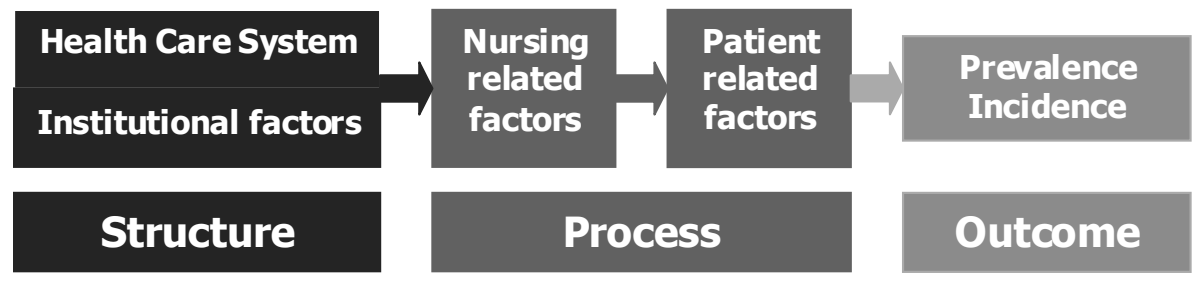

Figure 8.1 Factors influencing pressure ulcer prevalence and incidence rates (according to Donabedian's model).

\section{Structure}

In the prospective cohort study, we found a significantly higher pressure ulcer incidence in the Dutch nursing homes (33.3\%) compared to the German nursing homes (14.3\%). Out of the six factors that explained this difference, two were related to structural factors at the nursing home. One of these factors is the availability of a tissue viability nurse on the ward or at the nursing home, which was more common in the Dutch nursing homes. The availability of a tissue viability nurse was identified as a factor that increased the chance of 
pressure ulcer development among nursing home residents. This might be seen as a surprising result, as tissue viability nurses are recognised internationally as expert practitioners who could facilitate the implementation of evidence-based practice. ${ }^{26}$ However, this facilitation might be hampered if tissue viability nurses have difficulty articulating their role and nursing staff misunderstand the tissue viability nurse's role and tasks. ${ }^{26-28}$ Although tissue viability nurses are acknowledged as enabling rather than deskilling the nursing staff, support for their ideas depends on what the nursing staff views as their own role and tasks. Misunderstandings may lead to a poor working relationships if tissue viability nurses are thought to encroach on areas of work usually undertaken by the other nurses. ${ }^{29}$ This may also lead to nurses feeling threatened by the role of the tissue viability nurses. ${ }^{30}$ Therefore, a positive working relationship is a key factor for a successful collaboration. ${ }^{31}$ Besides the above-mentioned factors, tissue viability nurses also need the appropriate infrastructure and support at the nursing home to fulfil their tasks effectively. ${ }^{32}$

In conclusion, the effectiveness of appointing a tissue viability nurse depends on many factors. If these are not met, their efforts may be unsuccessful if their nursing colleagues are not receptive to their ideas, despite the best intentions of the tissue viability nurse.

The other structural factor explaining the difference in pressure ulcer incidence between the two countries was the performance of regular internal quality controls in the nursing homes, which were more common in the German nursing homes. Internal quality control within the healthcare sector is a widely discussed theme. ${ }^{33}$ Within the nursing home sector, there are several indicators of quality of care, also referred to as quality indicators. Examples of quality indicators are the prevalence of pressure ulcers, falls and incontinence. Quality indicators are widely used as a foundation for internal quality control and assurance and quality improvement activities. ${ }^{33,34}$

\section{Process}

Two of the factors that explained the difference in pressure ulcer incidence between the Dutch and German nursing homes in this thesis were related to the nursing care provided. These were the use of a transfer aid to reposition and/or transfer the resident in bed, from a bed to a chair and vice versa and resident repositioning. In our study, the use of a transfer aid increased the chance for developing a pressure ulcer. Other studies also found a negative relationship regarding the use of positioning devices and pressure ulcer development. ${ }^{1,35}$

In our study, resident repositioning decreased the chance of developing a pressure ulcer. Resident repositioning is a mainstay in most pressure ulcer prevention protocols and is seen as an appropriate strategy to prevent pressure ulcers. ${ }^{36}$ While most guidelines recommend turning every two hours, several studies report that there is insufficient 
evidence to recommend specific turning regimens. ${ }^{36,37}$ Therefore, we did not ask for specific turning regimens in our study, rather we asked if the resident had been repositioned according to a time schedule during the past 24 hours.

In addition, two factors related to nursing home residents explained the difference in pressure ulcer incidence between the Dutch and German nursing homes, namely suffering from dementia and the use of analgesics. Our study showed that suffering from dementia decreased the chance of developing a pressure ulcer. This finding has been supported by several other studies. ${ }^{38,39}$ A possible explanation could be that these residents have fewer mobility and activity limitations compared to other residents that suffer from (chronic) physical diseases. Furthermore it is conceivable that nurses pay more attention to these residents because these are prone to slide down the bed. ${ }^{38}$

The use of analgesics increased the chance of developing a pressure ulcer in our study. This has also been supported by other studies, which have shown that using analgesics may lead to altered pain perception and lower sensitivity to pressure and shear forces. ${ }^{40-42}$ Therefore, care should be taken with the prescription of analgesics and their use should be carefully evaluated. ${ }^{43}$

\section{Outcome}

The incidence of category 1 to 4 pressure ulcers in this thesis was significantly higher in the Dutch nursing homes (33.3\%) compared to the German nursing homes (14.3\%). Several other international studies investigating the incidence of pressure ulcers found rates varying from $2.2 \%$ to $39.4 \% .{ }^{1,3,44-47}$ Equated with these studies, the incidence rate in the Dutch nursing homes in our study is rather high, while the incidence rate in the German nursing homes is rather low. Investigating the incidence per pressure ulcer category revealed the same pattern for both countries: the incidence rates were higher in the Dutch nursing homes for all four categories, with the highest rate for category 1 pressure ulcers. This is comparable with other studies in which category 1 pressure ulcers were also the most common.

\section{METHODOLOGICAL CONSIDERATIONS}

In order to facilitate the interpretation of the results, a number of methodological issues regarding strengths and limitations should be considered.

\section{Design}

Chapters 2, 3, and 4 describe the studies for which semi-structured interviews were conducted. Interviews were chosen in order to obtain detailed information about the processes of guideline development, dissemination and implementation within different countries and from different disciplines and perspectives. Semi-structured interviews 
allow researchers to ask detailed questions, adapt questions as necessary, clarify doubt and ensure that the responses are properly understood. Compared to focus groups, interviewees are not influenced by others in the group. ${ }^{48}$

The interviews in the six European countries (chapter 2) were conducted to get an overview of the availability of national pressure ulcer guidelines in these countries and the way in which these were developed and disseminated to nursing homes. To verify, interviews were also held in three nursing homes in each country. Although this sample of three nursing homes in each country is rather small, the rationale for conducting the interviews in the nursing homes was to get a general impression of the dissemination of the national guideline to the nursing homes in that country, not to get an overview of the number of nursing homes in which the national pressure ulcer guideline was available.

The interviews in the Dutch and German nursing homes (chapters 3 and 4) were conducted in a heterogeneous sample of nursing homes. Nursing homes were included based on their variety of pressure ulcer prevalence rate, nursing home size and location. By including such a heterogeneous sample, we were able to see whether these differences influenced the process of pressure ulcer guideline implementation at these nursing homes.

The prospective cohort design (chapters 5 and 7) was chosen because until now, many studies concerning pressure ulcer development and risk factors have a cross-sectional or retrospective design. These designs make it difficult to investigate which factors influence the onset of pressure ulcers because they cannot provide insight into causal relationships. The prospective and longitudinal design of our study allowed us to investigate these factors and made it possible to make causal connections and closely monitor the development of a pressure ulcer. Moreover, this type of design is less vulnerable to measurement error, which is a risk in cross-sectional or retrospective studies. ${ }^{49,50}$ Furthermore, the study collected both data about the nursing home residents, the nursing care provided and structural factors at the nursing home. Most previous studies on pressure ulcer care have focused on only one of these factors. The present study made it possible to gain better insight into all these factors that may influence pressure ulcer prevalence and incidence rates and their interactions.

The prospective cohort study was set up as an observational study. One of this study's limitations was that the observations could not start immediately after nursing home admission. Before study participation, residents had to be informed about the study by the nursing staff or a member of the research team and needed to be given sufficient time to consider participation. Because of the essential and compulsory informed consent procedure, we could not enroll residents directly after nursing home admission. Furthermore, time to consider participation was also prolonged if informed consent had to be given by the legal representatives of the residents who were not able to give 
informed consent themselves. Due to this, we might have missed an important vulnerable period for the development of pressure ulcers. Furthermore, we chose a design in which residents were followed for a period of 12 weeks with weekly observations. This had the disadvantage that we were not able to monitor changes on a daily basis. Therefore, the observations were a random indication of the resident's condition and the pressure ulcer prevention and/or treatment provided during that week. For example, repositioning could have been given only that day or the condition of the resident could have been worse during the rest of the week.

Due to the nursing homes' participation in the cohort study, it is reasonable to assume that the awareness of nursing staff, medical staff and paramedical staff with regard to pressure ulcer prevention and treatment increased. Although this was an observational study, the study might have led to more alertness and nursing staff may have changed their behaviour because of the study.

\section{Study population}

The interviewees who participated in the interview studies in the Dutch and German nursing homes were representatives from different disciplines. This diverse sample allowed us to obtain information from different perspectives and to get an overall picture of the process of pressure ulcer guideline implementation at the different nursing homes.

The nursing homes that participated in the prospective cohort study were chosen from the Dutch national prevalence measurement of care problems database and the German government database for the federal states of Berlin and Brandenburg. The participating nursing homes were chosen at random. Not all nursing homes were willing to take part, mainly due to time issues and the involvement in other research projects at that point in time.

During the inclusion period for the prospective cohort study, $6.2 \%$ of the Dutch residents and $6.7 \%$ of the German residents who were screened for eligibility did not meet the inclusion criteria. In addition, $38.6 \%$ of the Dutch residents and $37.8 \%$ of the German residents who met the inclusion criteria refused to participate in our study. The most important reasons why residents refused to participate were that participation would take too much of their time and residents could not oversee what the outcome of the study would be. Also some residents refused to participate because their legal representative did not support their participation in the study. The consequences of this high refusing rate could be that the clinical characteristics of these residents differ from those of the residents who gave their informed consent. Furthermore, we excluded residents with an expected nursing home stay of less than 12 weeks and residents with a terminal illness from study participation. The exclusion of these residents may also have had consequences for the interpretation of our results, as it is possible that participating 
residents have other clinical characteristics than non-participating residents. For example, non-participating residents may have poorer physical conditions than participating residents.

The strength of the prospective cohort study is that we included both residents with and without a pressure ulcer at the start of the study and residents who had a high/low risk for pressure ulcer development in order to increase the generalisability of the study results.

Like in many studies, we had to deal with drop out during the study period. The dropout rate of residents in the Dutch nursing homes was $5.8 \%$, while the dropout rate in the German nursing homes was $26.9 \%$. The higher dropout rate in the German nursing homes was mainly caused by a higher rate of hospital admissions and because residents refused further participation. The lower hospital admission rate in the Dutch nursing homes can be explained by the fact that medical care in the Dutch nursing homes is provided by specially trained and employed nursing home physicians. As a result of the appointment of nursing home physicians, medical staff and advice are continuously available 24 hours a day. ${ }^{51}$

\section{RECOMMENDATIONS FOR CLINICAL PRACTICE}

This thesis has shown that pressure ulcer prevention and treatment in Dutch and German nursing homes shows signs of shortcomings. These shortcomings have led to the following recommendations for clinical practice.

As mentioned above, this thesis has shown that the implementation of guidelines is no sinecure. One way to encourage the implementation is by using active implementation strategies, as these have shown to be generally effective, ${ }^{16,52,53}$ in contrast to passive implementation strategies. ${ }^{15,16,54,55}$ Active implementation strategies include interactive educational meetings, discussion, feedback and the use of reminder systems. ${ }^{16,52,53}$ Another way to stimulate the implementation of guidelines is by eliminating the barriers faced during the implementation of pressure ulcer guideline recommendations. Barriers pointed out in this thesis include a lack of (qualified) staff, staff shortages, lack of time, insufficient knowledge concerning guideline recommendations, lack of motivation and poor communication. Furthermore, the implementation of the pressure ulcer guideline in daily practice can be improved by converting guideline recommendations into simple actions for nursing practice. This thesis has shown that repositioning and correctly using transfer aids to (re)position residents were the two nursing-related factors that were associated with a decreased chance of developing a pressure ulcer. These two factors should be brought more to the attention of both management and nursing staff in the nursing home sector. 
Moreover, the execution of these actions should be regularly checked and monitored, especially since a change in routines also involves a change in behaviour. Generating behavioural changes in care professionals is recognised as a difficult and complex process. This is confirmed by the studies in this thesis, which all showed that ineffective and outdated preventive measures were still frequently applied by nursing staff. Nursing staff still believed that these measures were effective and held on to their old habits. Educational programmes and coaching in daily practice should clarify why these harmful and outdated preventive measures are inefficient, so that nursing staff will stop believing in them and old habits will be eliminated. ${ }^{22}$

Furthermore, the studies in this thesis showed that the nursing staffs' overall knowledge about pressure ulcer care should be improved. Improved knowledge may lead to better use of guidelines in clinical practice. One way to improve knowledge is by providing sufficient education. The importance of education has been well demonstrated. ${ }^{56-59}$ Education raises awareness of the problem and provides the information needed to carry out prevention effectively. ${ }^{56}$ Providing adequate, sufficient and recurring education is essential to increase the knowledge level of the nursing staff at the nursing homes and to keep their knowledge up to date. Furthermore, the education provided should be compulsory for all nursing staff. However, education alone will be of limited value if this is not reflected in daily clinical practice. Successful pressure ulcer prevention also depends on the attitudes of nursing staff. ${ }^{19,60,61}$ A negative attitude can lead to non-application of preventive measures in clinical practice ${ }^{59,62}$, while a positive attitude makes it more likely that pressure ulcer preventive measures will be carried out. ${ }^{63}$ Additionally, the role and tasks of a tissue viability nurse working on the ward or at the nursing home should be clearly stated. Instead of being the person primarily (and sometimes perceived as 'only') responsible for pressure ulcer care on the ward, tissue viability nurses should focus on informing and coaching the rest of the ward's nursing staff so they can gain more knowledge about and experience with pressure ulcer prevention and treatment and pressure ulcer care can be incorporated in regular nursing care.

Finally, this thesis has shown that the performance of internal quality controls was one of the factors that decreased the chance of developing a pressure ulcer. Ideally, these controls should be carried out regularly. This can be accomplished, for instance, by having a person on every ward who is responsible for inspecting the quality of the nursing care provided on the ward, among which pressure ulcer care. To do so, it is essential that this person is able to provide effective nursing leadership, meaning that he or she has the task and responsibility of steering the nursing staff on the ward and functioning as a kind of 'head nurse'. The role of this person should be both to stimulate and monitor, and he or she should have the time and the skills to carry out these tasks. Adequate nursing professional leadership has been linked with good patient care and improved quality of care. ${ }^{64-68}$ Moreover, high levels of leadership support have been associated with low levels of pressure ulcer prevalence ${ }^{69}$ and leadership is at the core of nursing staff productivity. It 
is important to note that the position of the tissue viability nurse is different from that of the 'head nurse' mentioned above. The tissue viability nurse should focus on informing and coaching the nursing staff in the area of pressure ulcer care, whereas the focus of the 'head nurse' should be on stimulating and monitoring total nursing care.

\section{RECOMMENDATIONS FOR FUTURE RESEARCH}

This thesis has shown that country comparison studies can lead to useful new information and new insights. This country comparison study gave us a unique opportunity to find factors that probably would not have been found in a single country study.

Results from this thesis point to several recommendations for future research.

First, we recommend introducing an educational programme on pressure ulcer care for nursing staff employed in nursing homes to increase their knowledge level and keep their knowledge up to date. This programme should provide sufficient and recurrent education about pressure ulcer care for nursing staff. Furthermore, it should pay attention to stopping the use of non-useful preventive measures. Moreover, this educational programme should focus on the behavioural change of nursing staff.

Second we recommend a multifactorial intervention study. The intervention must focus both on structural as well as process aspects. The structural aspect of the intervention comprises the introduction of an internal quality control system at the nursing home. This control system should include more formal leadership by 'head nurses' related to daily nursing care, including pressure ulcer care. The focus of the control system should be on monitoring the execution of guideline recommendations. The process aspect of the intervention comprises the correct application of the preventive measures shown by this thesis as factors that decrease the chance of developing a pressure ulcer. These involve repositioning according to a time schedule, correct use of transfer aids to (re)position residents and control over the necessity of the use of analgesics. 


\section{REFERENCES}

1. Horn SD, Bender SA, Ferguson ML, Smout RJ, Bergstrom N, Taler G, Cook AS, Sharkey SS, Voss AC. The national pressure ulcer long-term care study: pressure ulcer development in long-term care residents. Journal of the American Geriatrics Society 2004;52:359-367.

2. Vanderwee K, Clark M, Dealey C, Gunningberg L, Defloor T. Pressure ulcer prevalence in Europe: a pilot study. Journal of Evaluation in Clinical Practice 2007;13:227-235.

3. De Souza DM, De Gouveia Santos VL. Incidence of pressure ulcers in the institutionalized elderly. Journal of Wound, Ostomy and Continence Nursing 2010;37:272-276.

4. Health Council of the Netherlands. Pressure ulcers. The Hague: Health Council of the Netherlands; 1999.

5. De Laat EHEW, Scholte op Reimer WJ, Van Achterberg T. Pressure ulcers: diagnostics and interventions aimed at wound-related complaints: a review of the literature. Journal of Clinical Nursing 2005;14:464-472.

6. Erwin-Toth P. Cost-effective pressure ulcer management in extended care. Ostomy Wound Management 1995;41:0889-5899.

7. Berlowitz DR, Brandeis GH, Anderson J, Du W, Brand H. Effect of pressure ulcers on the survival of long-term care residents. Journal of Gerontology: Medical Sciences 1997;52a:106-110.

8. Allman RM, Goode PS, Burst N, Bartolucci AA, Thomas DR. Pressure ulcers, hospital complications, and disease severity: impact on hospital costs and length of stay. Advances in Wound Care 1999;12:22-30.

9. Severens JL, Habraken JM, Duivenvoorden S, Frederiks CMA. The cost of illness of pressure ulcers in the Netherlands. Advances in Skin \& Wound Care 2002;15:72-77.

10. Bours GJJW, Halfens RJG, Lubbers M, Haalboom JRE. The development of a national registration form to measure the prevalence of pressure ulcers in the Netherlands. Ostomy Wound Management 1999;45:28-40.

11. Dassen T, Petermann B, Heinze C, Lahmann N, Lohrmann C, Mertens E, Tannen A. Dekubitus, Sturzereignisse, Pflegeabhängigkeit: Prävalenzerhebung 2002. Berlin: Institut für Medizin/Pflegepädagogik und Pflegewissenschaft; 2002.

12. Tannen A, Bours G, Halfens R, Dassen T. A comparsion of pressure ulcer prevalence rates in nursing homes in the Netherlands and Germany, adjusted for population characteristics. Research in Nursing \& Health 2006;29:588-596.

13. Tannen A, Dassen T, Halfens R. Differences in prevalence of pressure ulcers between the Netherlands and Germany: associations between risk, prevention and occurrence of pressure ulcers in hospitals and nursing homes. Journal of Clinical Nursing 2008;17:1237-1244.

14. Tannen A, Dietz E, Dassen T, Halfens R. Explaining the national differences in pressure ulcer prevalence between the Netherlands and Germany: adjusted for personal risk factors and institutional quality indicators. Journal of Evaluation in Clinical Practice 2009;15:85-90.

15. Oxman AD, Thomson MA, Davis DA, Haynes B. No magic bullets: a systematic review of 102 trials of interventions to improve professional practice. Canadian Medical Association Journal 1995;153:1423-1431.

16. Davis DA, Taylor-Vaisey A. Translating guidelines into practice: a systematic review of theoretic concepts, practical experience and research evidence in the adoption of clinical practice guidelines. Canadian Medical Association Journal 1997;157:408-416.

17. Grimshaw JM, Thomas RE, MacLennan G, Fraser C, Ramsay CR, Vale L, Whitty P, Eccles MP, Matowe L, Shirran L, Wensing M, Dijkstra R, Donaldson C. Effectiveness and efficiency of guideline dissemination and implementation strategies. Health Technology Assessment 2004;8:341-352. 
18. Clarke HF, Bradley C, Whytock S, Handfield S, Van der Wal R, Gundry S. Pressure ulcers: implementation of evidence-based nursing practice. Journal of Advanced Nursing 2005;49:578590.

19. Moore Z, Price P. Nurses' attitudes, behaviours and perceived barriers towards pressure ulcer prevention. Journal of Clinical Nursing 2004;13:942-951.

20. Panagiotopoulou K, Kerr SM. Pressure area care: an exploration of Greek nurses' knowledge and practice. Journal of Advanced Nursing 2002;40:285-296.

21. Benbow M. Quality of life and pressure ulcers. Journal of Community Nursing 2009;23:14-18.

22. Pancorbo-Hidalgo PL, Garcia-Fernandez FP, Lopez-Medina IM, Lopez-Ortega J. Pressure ulcer care in Spain: nurses' knowledge and clinical practice. Journal of Advanced Nursing 2007; 58:327-338.

23. Miyazaki MY, Caliri MH, Santos CB. Knowledge on pressure ulcer prevention among nursing professionals. Revista Latino-Americana de Enfermagem 2011;18:1203-1211.

24. Donabedian A. Criteria and standards for quality assessment and monitoring. Quality Review Bulletin 1986;12:99-108.

25. Donabedian A. Explorations in Quality Assessment and Monitoring, Volume I. The Definition of Quality and Approaches to its Assessment. Ann Arbour MI: Health Administration Press; 1980.

26. Austin L, Luker K, Martin R. Clinical nurse specialists and the practice of community nurses. Journal of Advanced Nursing 2006;54:542-552.

27. Redekopp M. Clinical nurse specialist role confusion: the need for identity. Clinical Nurse Specialist 1997;11:87-91.

28. Bamford O, Gibson F. The clinical nurse specialist role: key role components identified Managing Clinical Nursing 1999;2:105-109.

29. Haste FH, MacDonald LD. The role of the specialist in community nursing: perceptions of specialists and district nurses. International Journal of Nursing Studies 1992;29:37-47.

30. Bousfield C. A phenomenological investigation into the role of the clinical nurse specialist. Journal of Advanced Nursing 1997;25:245-256.

31. Lloyd Jones M. Role development and effective practice in specialist and advanced practice roles in acute hospital settings: systematic review and metasynthesis. Journal of Advanced Nursing 2005;49:191-209.

32. Audit Commission. First assessment: A review of district nursing services in England and Wales. Wales: Audit Commission; 1999.

33. Zimmerman DR. Improving nursing home quality of care through outcomes data: the MDS quality indicators. International Journal of Geriatric Psychiatry 2003;18:250-257.

34. Institute of Medicine. Improving the quality of care in nursing homes. Washington DC: National Academy Press; 1986.

35. Armstrong D, Bortz P. An integrative review of pressure relief in surgical patients. Association of periOperative Registered Nurses Journal 2001;73:645-674.

36. Reddy M, Gill SS, Rochon PA. Effective methods for preventing pressure ulcers. Journal of Family Practice 2006;55:942.

37. Lyder $\mathrm{CH}$. Pressure ulcer prevention and management. Annual Review of Nursing Research 2002;20:35-61.

38. Zulkowski K. MDS+ RAP items associated with pressure ulcer prevalence in newly institutionalized elderly: study I. Ostomy Wound Management 1998;44:40-53.

39. Margolis DJ, Knauss J, Bilker W, Baumgarten M. Medical conditions as risk factors for pressure ulcers in an outpatient setting. Age and Ageing 2003;32:259-264.

40. Allman RM. Pressure ulcer prevalence, incidence, risk factors, and impact. Clinics in Geriatric Medicine 1997;13:421-436. 
41. Boyle M, Green M. Pressure sores in intensive care: defining their incidence and associated factors and assessing the utility of two pressure sore risk assessment tools. Australian Critical Care 2001;14:24-30.

42. Smith M. A comprehensive review of risk factors related to the development of pressure ulcers. Journal of Orthopaedic Nursing 2003;7:94-102.

43. Grey JE, Harding KG, Enoch S. Pressure ulcers. British Medical Journal 2006;332:472-475.

44. Cuddigan J, Ayello EA, Sussman C, Baranoski S. Pressure ulcers in America: prevalence, incidence, and implications for the future. Reston VA: National Pressure Ulcer Advisory Panel; 2001.

45. Vanderwee K, Grypdonck MH, De Bacquer D, Defloor T. Effectiveness of turning with unequal time intervals on the incidence of pressure ulcer lesions. Journal of Advanced Nursing 2007;57:59-68.

46. Kwong EW, Pang SM, Aboo GH, Law SS. Pressure ulcer development in older residents in nursing homes: influencing factors. Journal of Advanced Nursing 2009;65:2608-2620.

47. Kwong EW, Lau AT, Lee RL, Kwan RY. A pressure ulcer prevention programme specially designed for nursing homes: does it work? Journal of Clinical Nursing 2011;20:2777-2786.

48. Lindlof TR, Taylor BC. Qualitative communication research methods. 2nd ed. Thousand Oaks CA: Sage Publications; 2002.

49. Hudson JI, Pope HG, Jr., Glynn RJ. The cross-sectional cohort study: an underutilized design. Epidemiology 2005;16:355-359.

50. White E, Hunt JR, Casso D. Exposure measurement in cohort studies: The challenges of prospective data collection. Epidemiologic Reviews 1998;20:43-56.

51. Schols JMGA, Crebolder HFJM, van Weel C. Nursing home and nursing home physician: the Dutch experience. Journal of the American Medical Directors Association 2004;5:207-212.

52. Bero LA, Grilli R, Grimshaw JM, Harvey E, Oxman AD, Thomson MA. Closing the gap between research and practice: an overview of systematic reviews of interventions to promote the implementation of research findings. The Cochrane Effective Practice and Organization of Care Review Group. British Medical Journal 1998;317:465-468.

53. National Health Service Centre for Reviews and Dissemination. Getting evidence into practice. Effective Health Care 1999;5:1-16.

54. Feder G, Eccles M, Grol R, Griffiths C, Grimshaw J. Using clinical guidelines. British Medical Journal 1999;318:728-730.

55. Grimshaw JM, Shirran L, Thomas R, Mowatt G, Fraser C, Bero L, Grilli R, Harvey E, Oxman A, O'Brien MA. Changing provider behavior: an overview of systematic reviews of interventions. Medical Care 2001;39:2-45.

56. Benbow M. Keeping the pressure off. Nursing the Elderly 1992;4:17-19.

57. Maylor ME. Knowledge base and use in the management of pressure sores. Journal of Wound Care 1997;6:244-247.

58. Arblaster G. Pressure sore incidence: a strategy for reduction. Nursing Standard 1998;12:49-52.

59. Källman U, Suserud BO. Knowledge, attitudes and practice among nursing staff concerning pressure ulcer prevention and treatment: a survey in a Swedish healthcare setting. Scandinavian Journal of Caring Sciences 2009;23:334-341.

60. Land L. A review of pressure damage prevention. Journal of Advanced Nursing 1995;22:329337.

61. Anthony DM. The formation of pressure sores and the role of nursing care. Journal of Wound Care 1996;5:192-194.

62. Buss IC, Halfens RJG, Huijer Abu-Saad H, Kok G. Pressure ulcer prevention in nursing homes: views and beliefs of enrolled nurses and other health care workers. Journal of Clinical Nursing 2004;13:668-676. 
63. Maylor M, Torrance C. Pressure sore survey. Part 3: Locus of control. Journal of Wound Care 1999;8:101-105.

64. Kramer M, Schmalenberg C. Magnet hospitals - Part I: Institutions of excellence. Journal of Nursing Administration 1988;18:13-24.

65. Kramer M, Schmalenberg C. Magnet hospitals - Part II: Institutions of excellence Journal of Nursing Administration 1988;18:1-11.

66. McClure M, Poulin M, Sovie M, Wandelt M. Magnet hospitals: Attraction and retention of professional nurses (The Original Study). In Magnet hospitals revisited. (McClure M, Hinshaw A, eds.), Washington DC: American Academy of Nurses; 2002.

67. Gilley A, McMillan H, Gilley J. Organizational change and characteristics of leadership effectiveness. Journal of Leadership and Organizational Studies 2009;16:38-47.

68. Strodeur S, Vandenberghe C, D'hoore W. Leadership styles across hierarchical levels in nursing departments. Nursing Research 2000;49:37-43.

69. Boyle SM. Nursing unit characteristics and patient outcomes. Nursing Economics 2004;22:111 119. 
SUMMARY 


\section{SUMMARY}

Within the nursing home sector pressure ulcers are a common and serious health care problem. They cause a major burden in terms of patient suffering and frustration and can result in a decreased quality of life, increased morbidity and mortality rates, an increased need for intensive nursing and medical care and, as a consequence, increased healthcare costs.

In the Netherlands and Germany annual pressure ulcer prevalence surveys have been conducted since 1998 (NL) and 2001 (GER) using the same standardized definitions, instruments and methodology. Results of these surveys reveal large differences in prevalence rates between both countries in nursing homes over the past ten years. Prevalence rates over three times as high in Dutch nursing homes (30.8\%) compared to the German ones (8.3\%) have been reported.

The difference in pressure ulcer prevalence rates between nursing homes in the Netherlands and Germany has been studied previously. However, no full explanation could be found for this difference, partly because of the cross-sectional design of the prevalence studies, which makes it impossible to draw causal relationships and because of the fact that some relevant factors for pressure ulcer development could not be measured during the prevalence studies.

The studies in this thesis were set up to investigate the differences in pressure ulcer care between nursing homes in the Netherlands and Germany by measuring the incidence of pressure ulcers and possible related factors with respect to the nursing home residents, the nursing care provided and attributes of the care setting, such as the availability and implementation of a pressure ulcer guideline.

The general introduction of this thesis (Chapter 1), addresses background information on pressure ulcer care, prevalence and incidence rates and factors associated with the development of pressure ulcers. Furthermore, the aims and outline of the thesis are presented in this chapter.

Chapter $\mathbf{2}$ describes a qualitative study which explored the process of pressure ulcer guideline development and dissemination from national to nursing home level in six European countries: England, Germany, Italy, the Netherlands, Portugal and Sweden. Semi-structured interviews were conducted at national and nursing home level. The interviews revealed a variety of similarities and differences regarding the development and dissemination process of pressure ulcer guidelines in these countries. The strategies used to disseminate national pressure ulcer guidelines in the six countries differed in terms of number and type of used strategies. Nevertheless, all national organizations used a multifaceted strategy. The dissemination barrier mentioned most often was lack of money.

Chapter 3 describes another qualitative study which investigated the process of pressure ulcer guideline dissemination and implementation in Dutch nursing homes. Semistructured interviews were conducted in eight nursing homes in the Netherlands. In each nursing home, interviews were held with eight representatives. All eight participating 
nursing homes had institutional pressure ulcer prevention and treatment guidelines and the dissemination of the guidelines to the nursing staff seemed to be successful. Nevertheless, the actual implementation of the pressure ulcer guidelines was lacking in all of the nursing homes. Barriers to apply guideline recommendations in daily practice were mostly related to a lack of (qualified) personnel, a lack of nurses/nursing assistants' knowledge and poor communication.

In Chapter 4 the results of the study described in chapter 3 were compared with the results of a qualitative study conducted in ten German nursing homes. Both studies used the same design and methodology. The interviews conducted in both countries revealed that all nursing homes in both countries had institutional pressure ulcer prevention and treatment guidelines. Nevertheless, the implementation of pressure ulcer guidelines in daily practice of the Dutch and German nursing homes could be improved. Implementation barriers were related to unqualified personnel, staff shortages, additional work load and lack of motivation. Furthermore, insufficient knowledge concerning guideline recommendations was observed during the interviews with the nurses and nursing assistants, both in Dutch and German nursing homes. Although pressure ulcer education was offered in both countries in most nursing homes, attendance was not obligatory in the Dutch nursing homes.

In Chapter $\mathbf{5}$ the design of a cohort study is presented. This study was set up as a prospective multicenter cohort study, to investigate the incidence of pressure ulcers in nursing homes in the Netherlands and Germany and to identify patient related factors, nursing related factors and structural factors associated with pressure ulcer development. The study population consisted of newly admitted nursing home residents in 10 Dutch and 11 German nursing homes which were followed for a period of 12 weeks. Data were collected by independent research assistants by means of weekly observations using questionnaires both on resident, nursing staff, ward and nursing home level.

Chapter 6 describes the results of the nursing staff questionnaire described in chapter 5 , which examined the knowledge and use of pressure ulcer preventive measures among nursing staff in the Dutch and German nursing homes that participated in the prospective multicenter cohort study. The knowledge among nursing staff about useful pressure ulcer preventive measures was moderate in both countries, while non-useful preventive measures were poorly known. The same pattern could be seen with regard to the use of preventive measures, since non-useful preventive measures were still commonly used according to the respondents. These results indicate that further efforts are still required to improve knowledge about pressure ulcer preventive measures among nursing staff in nursing homes in both the Netherlands and Germany.

The next chapter (Chapter 7) reports on the main outcomes of the prospective multicenter cohort study described in chapter 5 . The results of this study showed that the pressure ulcer incidence during the first 12 weeks after admission was much higher in the Dutch nursing homes $(33,3 \%)$ compared to the German nursing homes $(14,3 \%)$. Six factors were identified which explained the difference in pressure ulcer incidence rates between nursing homes in both countries. Two of these factors were related to the nursing home 
residents: suffering from dementia and the use of analgesics. Two factors were related to the nursing care provided: the use of transfer aids and repositioning the residents. Finally, two factors were related to structural factors at the nursing home: the availability of a tissue viability nurse on the ward and regular internal quality controls in the nursing home. Of these six factors, three were more common in Dutch nursing homes: the necessity to use a transfer aid to reposition and/or transfer the resident, the availability of a tissue viability nurse working on the ward and the use of analgesics. The occurrence of one or more of these factors increased the chance of developing a pressure ulcer. The other three factors were more common in the German nursing homes: repositioning the resident, suffering from dementia and regular internal quality control in the nursing home. The existence of one or more of these factors decreased the chance of developing a pressure ulcer. This study concluded that continuous attention to pressure ulcer care is important for all healthcare settings and countries, but Dutch nursing homes especially should pay more attention to repositioning residents, the necessity and correct use of transfer aids, the necessity of analgesics use, the tasks of the tissue viability nurse and the performance of regular internal quality controls.

The general discussion in Chapter $\mathbf{8}$ provides an overview and discussion of the main findings presented in the previous chapters of this thesis. Theoretical and methodological considerations are addressed. Furthermore, the following recommendations for clinical practice were made: stimulate the implementation of pressure ulcer guidelines by using active implementation strategies, by eliminating implementation barriers, and by converting guideline recommendations into simple actions for nursing practice. Provide adequate, sufficient and recurring compulsory education to increase the knowledge level of the nursing staff and to keep their knowledge up to date. Clearly state the role and tasks of a tissue viability nurse working on the ward or at the nursing home. Their focus should be on informing and coaching the rest of the ward's nursing staff to gain more knowledge about and experience with pressure ulcer prevention and treatment. Carry out regular internal quality controls within the nursing home. Finally, recommendations for future research are presented. 
NEDERLANDSE SAMENVATTING 


\section{NEDERLANDSE SAMENVATTING}

In de gezondheidszorg is decubitus nog steeds een veel voorkomend zorgprobleem. Decubitus betekent voor de patiënt pijn en overlast en kan resulteren in een verminderde kwaliteit van leven, hogere morbiditeit- en mortaliteitscijfers, meer verpleegkundige en medische zorg en, als resultaat hiervan, hogere kosten.

In Nederland wordt sinds 1998 jaarlijks de Landelijke Prevalentiemeting Zorgproblemen (LPZ) uitgevoerd waarbij de prevalentie, preventie en behandeling van zorgproblemen, waaronder decubitus, in diverse gezondheidszorginstellingen gemeten wordt. Sinds 2001 wordt ook in Duitsland deze meting jaarlijks uitgevoerd. Beide landen hanteren dezelfde gestandaardiseerde definities, methodologie en vragenlijsten. Resultaten van deze jaarlijkse metingen laten in de afgelopen 10 jaar grote verschillen zien in decubitusprevalentiecijfers tussen beide landen, in het bijzonder in de verpleeghuissector. Prevalentiecijfers in Nederlandse verpleeghuizen (30.8\%) liggen vele malen hoger dan die in Duitse verpleeghuizen (8.3\%). Deze verschillen in decubitus-prevalentie tussen beide landen zijn in eerdere studies onderzocht. Deze onderzoeken hebben echter geen volledige verklaring kunnen vinden voor dit verschil. Dit wordt deels veroorzaakt door het cross-sectionele design van de prevalentiemetingen, waardoor geen causale verbanden aangetoond kunnen worden. Daarnaast is het bij deze prevalentiemetingen niet mogelijk om alle factoren die de prevalentie van decubitus mogelijk kunnen beïnvloeden te meten. Het onderzoek beschreven in dit proefschrift is opgezet om de verschillen in decubituszorg tussen verpleeghuizen in Nederland en Duitsland nader te onderzoeken. Hierbij wordt gekeken naar de incidentie van decubitus en mogelijke verklarende factoren, zowel gerelateerd aan de verpleeg-huisbewoners, de verleende verpleegkundige zorg en structurele kenmerken van de verpleeghuisorganisaties, zoals de aanwezigheid en implementatie van een decubitus-richtlijn.

De algemene inleiding van dit proefschrift (Hoofdstuk 1) geeft achtergrondinformatie over het zorgprobleem decubitus, het ontstaan van decubitus en factoren die het ontstaan van decubitus kunnen beïnvloeden. Verder worden in dit hoofdstuk de doelstellingen en de opzet van het proefschrift toegelicht.

Hoofdstuk 2 beschrijft een kwalitatieve studie waarin de ontwikkeling en verspreiding van decubitus-richtlijnen (van nationaal niveau tot verpleeghuisniveau) werd onderzocht in zes Europese landen: Engeland, Duitsland, Italië, Nederland, Portugal en Zweden. Met vertegenwoordigers van de organisaties die de nationale richtlijn decubitus hebben ontwikkeld en met representanten van diverse verpleeghuizen werden semigestructureerde interviews gehouden. De interviews hebben een reeks van overeenkomsten en verschillen naar voren gebracht in de ontwikkeling en verspreiding van decubitus-richtlijnen tussen deze landen. Verschillen waren zichtbaar in de strategieën die werden toegepast bij de verspreiding van de landelijke/regionale decubitus-richtlijn naar verpleeghuis niveau. Ook waren er verschillen zichtbaar in het aantal strategieën dat werd gebruikt voor het verspreiden van de richtlijn. In alle landen werd gebruik gemaakt van meer dan één 
strategie. De meeste genoemde barrière bij de verspreiding van de decubitus-richtlijn was geldgebrek.

Hoofdstuk 3 beschrijft een tweede kwalitatieve studie, waarin de verspreiding en implementatie van decubitus-richtlijnen in Nederlandse verpleeghuizen werd onderzocht. In acht verpleeghuizen in Nederland werden semigestructureerde interviews gehouden. In elk verpleeghuis werden interviews gehouden met acht vertegenwoordigers. Verpleeghuisbrede richtlijnen voor de preventie en behandeling van decubitus waren aanwezig in alle deelnemende verpleeghuizen. De verspreiding van de decubitus-richtlijn naar de afdeling en het verpleegkundig personeel was succesvol. Echter, de implementatie van de richtlijn schoot in alle verpleeghuizen tekort. Barrières in het toepassen van de aanbevelingen vanuit de richtlijn in de praktijk waren voornamelijk gerelateerd aan een gebrek aan (gekwalificeerd) personeel, gebrek aan kennis bij verpleegkundig personeel en gebrekkige communicatie.

In Hoofdstuk 4 worden de resultaten van de studie die is beschreven in Hoofdstuk 3 vergeleken met de resultaten van een vergelijkbare kwalitatieve studie uitgevoerd in 10 verpleeghuizen in Duitsland. In beide studies werd dezelfde methodologie gehanteerd. De interviews toonden aan dat richtlijnen voor de preventie en behandeling van decubitus aanwezig waren in alle verpleeghuizen in beide landen. Echter, de implementatie van de richtlijn in de dagelijkse praktijk behoeft verbetering. Barrières bij de implementatie van de richtlijn zijn gerelateerd aan personeelstekort, onvoldoende gekwalificeerd personeel, hoge werkdruk en gebrek aan motivatie. Daarnaast toonden de interviews aan dat de kennis over preventieve maatregelen bij decubitus onder het verpleegkundig personeel ontoereikend is. Hoewel in het merendeel van de verpleeghuizen in beide landen scholing werd aangeboden aan het verpleegkundig personeel, was het volgen van deze scholing geen verplichting in de Nederlandse verpleeghuizen.

Hoofdstuk 5 schetst het studieprotocol en de methoden van het onderzoek waarin de incidentie van decubitus in verpleeghuizen Nederland en Duitsland werd onderzocht. Dit onderzoek had tevens tot doel factoren op te sporen die het ontwikkelen van decubitus kunnen verklaren. Het betreft een prospectieve cohortstudie waarbij nieuw opgenomen verpleeghuisbewoners in 10 Nederlandse en 11 Duitse verpleeghuizen voor een periode van 12 weken werden gevolgd. Data werden verzameld door getrainde onderzoeksassistenten door middel van wekelijkse observaties. Daarnaast werden vragenlijsten gehanteerd op het niveau van de verpleeghuisbewoner, het verpleegkundig personeel, de afdeling en het verpleeghuis.

In Hoofdstuk 6 worden de resultaten van de in Hoofdstuk 5 benoemde vragenlijst op het niveau van het verpleegkundig personeel weergegeven. De vragenlijst had tot doel inzicht te krijgen in de kennis over en het gebruik van, al dan niet zinvolle, preventieve decubitusmaatregelen onder verpleegkundig personeel in de Nederlandse en Duitse verpleeghuizen die deelnamen aan de prospectieve cohortstudie. Kennis aangaande zinvolle preventieve maatregelen was middelmatig in beide landen. Kennis over niet zinvolle maatregelen was gebrekkig. Hetzelfde patroon was zichtbaar met betrekking tot de toepassing van preventieve maatregelen. Niet zinvolle maatregelen werden regelmatig 
toegepast in de praktijk. Deze resultaten tonen aan dat zowel in Nederlandse als Duitse verpleeghuizen meer inspanningen nodig zijn om de kennis over en toepassing van preventieve decubitusmaatregelen te verbeteren onder verpleegkundig personeel.

In het volgende hoofdstuk (Hoofdstuk 7) worden de belangrijkste uitkomsten van de prospectieve cohortstudie, zoals beschreven in Hoofdstuk 5, weergegeven. De resultaten van deze studie tonen aan dat de incidentie van decubitus gedurende de eerste 12 weken na opname in het verpleeghuis vele malen hoger is in de Nederlandse verpleeghuizen $(33,3 \%)$ in vergelijking tot de verpleeghuizen in Duitsland $(14,3 \%)$. In totaal werden 6 factoren gevonden die het verschil in decubitus-incidentie tussen beide landen verklaren. Twee van deze factoren zijn gerelateerd aan de verpleeghuisbewoners: lijden aan dementie en het gebruik van analgetica. Twee factoren zijn gerelateerd aan de verleende zorg: het gebruik van transfer-hulpmiddelen en het toepassen van wisselligging. Tenslotte zijn er twee factoren gerelateerd aan de structuur van het verpleeghuis: de aanwezigheid van een decubitus verpleegkundige op de afdeling en het regelmatig uitvoeren van interne kwaliteitscontroles binnen het verpleeghuis.

Van deze zes factoren kwamen er 3 meer voor in de Nederlandse verpleeghuizen; het gebruik van transfer hulpmiddelen bij de verpleeghuisbewoner, de aanwezigheid van een decubitus-verpleegkundige op de afdeling en het gebruik van analgetica. De aanwezigheid van één of meer van deze factoren verhoogt het risico op het ontwikkelen van decubitus. De andere 3 factoren kwamen meer voor in de Duitse verpleeghuizen, namelijk het toepassen van wisselligging, de diagnose dementie en het regelmatig uitvoeren van interne kwaliteitscontroles binnen het verpleeghuis. De aanwezigheid van één of meer van deze factoren verlaagt het risico op het ontwikkelen van decubitus. Conclusies van deze studie waren dat continue aandacht voor decubituszorg essentieel is voor alle landen en alle type zorginstellingen. Specifiek in Nederlandse verpleeghuizen zou meer aandacht besteedt moeten worden aan het toepassen van wisselligging bij bewoners, het gebruik van hulpmiddelen bij de transfer van verpleeghuisbewoners, de noodzaak van het gebruik van analgetica, de taken van de decubitus-verpleegkundige en het uitvoeren van regelmatig terugkerende interne kwaliteitscontroles.

De algemene discussie (Hoofdstuk 8) geeft een overzicht en discussie van de belangrijkste resultaten beschreven in de voorgaande hoofdstukken van dit proefschrift. Theoretische en methodologische overwegingen worden hier ook toegelicht. Daarnaast worden in dit hoofdstuk een aantal aanbevelingen voor de praktijk gedaan. Aanbevolen wordt de implementatie van de richtlijn decubitus te stimuleren door actieve implementatiestrategieën te gebruiken, barrières in de implementatie te elimineren en aanbevelingen vanuit de richtlijn decubitus om te zetten in eenvoudige acties voor de dagelijkse praktijk. Daarnaast wordt aanbevolen om adequate, toereikende en terugkerende verplichte scholing aan te bieden voor verpleegkundig personeel om hun kennis over decubitus te verbeteren en actueel te houden. Ook wordt aanbevolen de rol en de taken van een decubitus-verpleegkundige duidelijk te specificeren. Tevens wordt aanbevolen om regelmatig terugkerende interne kwaliteitscontroles uit te voeren in het verpleeghuis. Tot slot worden in dit hoofdstuk aanbevelingen voor toekomstig onderzoek gedaan. 


\section{DANKWOORD}




\section{DANKWOORD}

Lang heb ik uitgekeken naar dit moment, na zoveel jaar onderzoek is mijn proefschrift een feit! Dit proefschrift had er niet gelegen zonder de hulp en steun van velen. ledereen die een bijdrage heeft geleverd aan de totstandkoming van dit proefschrift wil ik natuurlijk bedanken en een aantal mensen in het bijzonder.

Mijn promotieteam, bestaande uit Prof. dr. Jos Schols, Prof. dr. Christa Lohrmann en Dr. Ruud Halfens. Bedankt voor de prettige samenwerking en begeleiding en het vertrouwen dat jullie in mij hebben gehad om dit onderzoek tot een goed einde te brengen.

Beste Jos, ik wil je graag danken voor je niet afhoudende betrokkenheid bij het onderzoek, je aanstekelijke enthousiasme en je inspirerende en vernieuwende ideeën. Jouw expertise en brede blik op onderzoek en praktijk hebben mij enorm geholpen gedurende de opzet en uitvoering van het onderzoek.

Dear Christa, I would like to thank you for your positive feedback, critical questions and notes. Many thanks for your quick replies, encouragements and fruitful discussions during our meetings. Your precision and attention to detail has improved the draft versions of the manuscripts considerably.

Beste Ruud, bedankt voor het vertrouwen dat jij de afgelopen jaren in mij hebt gehad. Onze overleggen en discussies hebben mij altijd gestimuleerd en geënthousiasmeerd. Bedankt voor de vrijheid die je me hebt gegeven om zelf op onderzoek uit te gaan. Voor de verschillende studies hebben we heel wat verpleeghuizen van binnen mogen bekijken en onze verwondering uit mogen spreken over de diversiteit hierin!

Mijn dank gaat ook uit naar Rianne de Wit. Beste Rianne, tijdens de eerste twee jaar van mijn promotietraject was jij als promotor betrokken. Bedankt voor de inspirerende discussies, je kritische feedback en de prettige samenwerking; het is spijtig dat deze vroeger dan gepland geëindigd is.

De leden van de beoordelingscommissie, dr. G.J.J.W. Bours, prof. dr. C. Lindholm, prof. dr. G. Meyer en prof. dr. T. Van der Weijden, onder voorzitterschap van prof. dr. J.P.H. Hamers, dank ik hartelijk voor het lezen en beoordelen van mijn proefschrift.

Geen onderzoek zonder deelnemers. Mijn dank gaat uit naar alle bewoners en hun vertegenwoordigers voor hun deelname aan het onderzoek en hun medewerking bij het beantwoorden van de vragenlijsten. Mijn dank gaat ook uit naar al het personeel (verpleegkundig, verzorgend, medisch en paramedisch), de afdelingshoofden, contactpersonen en bestuurders van de verpleeghuizen in Nederland en de diverse Europese landen die deel hebben genomen aan de verschillende deelonderzoeken 
beschreven in dit proefschrift. Bedankt voor jullie ondersteuning en jullie inspanningen bij het uitvoeren van de studies.

Jacques Neyens en Miriam Gigase, heel hartelijk dank voor jullie inspanningen bij de dataverzameling. Jullie hebben bergen werk verzet en zonder jullie hulp was het niet mogelijk geweest alle data bij de vele bewoners te verzamelen. Dankzij jullie is de dataverzameling goed en vlot verlopen.

Het team dat verantwoordelijk is geweest voor de dataverzameling in de Duitse verpleeghuizen wil ik ook graag bedanken. Dear Cornelia, Doris, Theo and the German research assistants, thank you all for the pleasant collaboration and your efforts in performing the data collection in the German nursing homes.

Marieke Spreeuwenberg en Ton Ambergen, bedankt voor jullie hulp en adviezen bij de statistische analyses die dankzij jullie heldere uitleg ook voor mij duidelijk werden. Marieke bedankt ook voor je hulp bij het beschrijven van deze analyses in het artikel.

Tiny Wouters bedank ik voor het verzorgen van de opmaak van dit proefschrift.

Mijn collega's van de LPZ. Judith, als kamergenoot en treinmaatje hebben wij heel wat tijd samen doorgebracht. Bij vragen kon ik altijd bij je terecht. Bedankt voor je luisterend oor en adviezen en vooral ook voor de gezelligheid. Suzanne en Saskia, bedankt voor de fijne samenwerking en jullie ondersteuning bij allerlei klussen. Donja, bedankt de gezellige lunchwandelingen!

Mijn collega's van de vakgroep, welke in de afgelopen jaren vele namen heeft gekend... Bedankt voor de leuke gesprekken, bij de koffiecorner, tijdens congressen en lunchwandelingen.

Noémi, wat hebben we samen veel gelachen de afgelopen jaren. Vanaf dag één hebben we een kantoor gedeeld en, hoe cliché ook, lief en leed gedeeld. Je bent altijd attent, staat voor iedereen klaar en niets is te gek. Je hebt zelfs voor mijn verjaardag een keer sushi gemaakt! Ik hoop dat we nog veel samen kunnen lachen. Bedankt dat jij vandaag als paranimf aan mijn zijde wilt staan, binnenkort is het jouw beurt een dankwoord te schrijven!

Jeroen, ik vraag me soms af hoe we het voor elkaar krijgen om steeds op grote afstand van elkaar te gaan wonen. Toen ik in Maastricht ging studeren koos jij voor Groningen en toen jij verhuisde naar Antwerpen woonde ik in Weert. Nu is Zwolle al weer een tijdje de plek waar jij en Inge je helemaal thuis voelen. Ondanks de afstand spreken we elkaar gelukkig vaak genoeg en is er altijd teveel om over bij te kletsen. Bedankt voor je betrokkenheid, je droge humor en je oneliners, ik denk trouwens dat dit in de familie zit;-) Je bent een hele 
trotse peetoom en vandaag vervul je weer een voor mij speciale rol door naast mij te staan als paranimf. Bedankt broertje!

Mijn lieve vriendinnen! Bedankt voor jullie interesse in mijn werk en voor de afleiding van het onderzoek de afgelopen jaren tijdens weekendjes weg, dispuutsdagen en vele koppen koffie en thee. We zullen straks samen proosten met een biertje en voor mij natuurlijk een cassis!

Mijn (schoon) familie, bedankt voor jullie interesse in mijn werk. Lieve pap en mam, bij jullie kan ik altijd terecht voor een luisterend oor, advies en wijze raad. De afgelopen jaren hebben we samen veel mooie en helaas ook minder mooie momenten mee mogen maken. Ik ben heel blij dat de mooie momenten weer overheersen en ik ben trots dat jullie vandaag op de eerste rij zitten!

De laatste woorden heb ik bewaard voor mijn thuisbasis. Lieve Jeroen, bedankt voor je steun, luisterend oor, nuchterheid, geloof in mij, liefde en de nodige afleiding en opbeurende woorden als ik even door de bomen het bos niet meer zag. Dankzij jou ziet de omslag van dit proefschrift er prachtig uit! Lieve Tijn en Bente, wat is het heerlijk om jullie te zien opgroeien en te zien hoe jullie zelf op onderzoek uitgaan. Geen dag is hetzelfde en een leukere afleiding van het werk is er niet. Mama is trots op jullie! 
ABOUT THE AUTHOR 


\section{ABOUT THE AUTHOR}

Esther Meesterberends was born in Enschede, the Netherlands, on the $29^{\text {th }}$ of November 1982. She attended secondary school (VWO) at the Noordik in Almelo. After her graduation she studied Nursing at Saxion Hogeschool in Enschede. After obtaining here bachelor's degree in Nursing in June 2004, she followed the master Physical Activity and Health at Maastricht University. In September 2006, she received a master's degree in Physical Activity and Health after finishing her thesis concerning the influence of activity patterns and food patterns on overweight and obesity in school children.

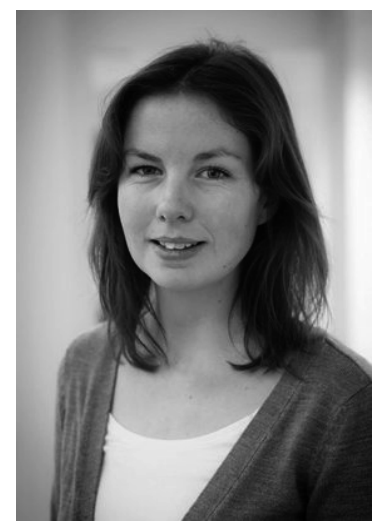

In February 2007, Esther took up a PhD student position at Maastricht University working on the research which is presented in this PhD thesis under supervision of Prof. dr. Jos Schols, Prof. dr. Christa Lohrmann and dr. Ruud Halfens.

During the PhD trajectory she followed master courses in Epidemiology at the Institute for Research in Extramural Medicine (EMGO Institute) of the VU University Medical Center Amsterdam, participated in the Nursing Science PhD program organized jointly by Maastricht University, Berlin's Charité University and the University of Graz, and coorganized the European Doctoral Conference in Nursing Science (EDCNS) in Maastricht in 2008 and 2011. In 2010 Esther completed the three-year Ph.D. summer course of the European Academy of Nursing Science (2008-2010). Since 2008 she is a member of the European Pressure Ulcer Advisory Panel (EPUAP). From 2011 on she is a trustee of the EPUAP.

Since September 2013, Esther works as a research fellow based in the Innovations in Care for the Elderly research programme at the CAPHRI School for Public Health and Primary Care at Maastricht University. Her research activities are aimed at the optimization of pressure ulcer care and the further improvement of scientific research in this field. Furthermore, she is working as a researcher for the Landelijke Prevalentiemeting Zorgproblemen (LPZ) at the same University. 
LIST OF PUBLICATIONS 


\section{LIST OF PUBLICATIONS}

\section{International journal articles}

Halfens RJG, Meesterberends E, van Nie-Visser NC, Lohrmann C, Schönherr S, Meijers JM, Hahn S, Vangelooven C, Schols JMGA. International prevalence measurement of care problems: results. Journal of Advanced Nursing 2013;69:e5-e17.

Van Nie-Visser NC, Schols JMGA, Meesterberends E, Lohrmann C, Meijers JM, Halfens RJG. An international prevalence measurement of care problems: study protocol. Journal of Advanced Nursing 2013;69:e18-29.

Meesterberends E, Wilborn D, Lohrmann C, Schols JMGA, Halfens RJG. Knowledge and use of pressure ulcer preventive measures in nursing homes: a comparison of Dutch and German nursing staff. Journal of Clinical Nursing 2013. In press. doi: 10.1111/jocn.12352.

Meesterberends E, Halfens RJG, Spreeuwenberg MD, Ambergen TA, Lohrmann C, Neyens JC, Schols JMGA. Do patients in Dutch nursing homes have more pressure ulcers than patients in German nursing homes? A prospective multicenter cohort study. Journal of the American Medical Directors Association 2013;14:605-610.

Breimaier HE, Halfens RJG, Wilborn D, Meesterberends E, Nielsen GA, Lohrmann C. Implementation interventions used in nursing homes and hospitals: a descriptive, comparative study between Austria, Germany, and The Netherlands. ISRN Nursing 2013; ID706054.

Breimaier HE, Eichhorn-Kissel J, Kottner J, Meesterberends E, Meijers J, van Nie-Visser N. Editorial: The meaning of being a guest editor - a real challenge! Journal of Clinical Nursing 2011;20:2383-2384.

Meesterberends E, Halfens RJG, Heinze C, Lohrmann C, Schols JMGA. Pressure ulcer incidence in Dutch and German nursing homes: design of a prospective multicenter cohort study. BMC Nursing 2011;10:8.

Meesterberends E, Halfens RJG, Lohrmann C, Schols JMGA, de Wit R. Evaluation of the dissemination and implementation of pressure ulcer guidelines in Dutch nursing homes. Journal of Evaluation in Clinical Practice 2011;17:705-712.

Meesterberends E, Halfens RJG, Lohrmann C, de Wit R. Pressure ulcer guideline development and dissemination in Europe. Journal of Clinical Nursing 2010;19:1495-1503. 


\section{National journal articles}

Schols JMGA, Meijers JJM, van Nie NC, Meesterberends E, Neyens JCL, Halfens RJG. De Landelijke Prevalentiemeting Zorgproblemen (LPZ), na meer dan 15 jaar nog steeds actueel en belangrijk voor de zorgkwaliteit. WCS Nieuws 2013;29:4-6.

Halfens RJG, Meijers JMM, van Nie-Visser NC, Meesterberends E, Neyens JCL, Schols JMGA. Van meten naar implementeren: 15 jaar prevalentiemetingen. Tijdschrift voor Gezondheidswetenschappen 2012;90:401-405.

\section{Reports}

Meesterberends E, Halfens RJG. Standaardisatie van decubituszorg in de regio: Een eerste verkenning. Maastricht: Nefemed; 2013.

Halfens RJG, Meijers JMM, Meesterberends E, van Nie NC, Neyens JCL, Rondas ALM, Schols JMGA. Rapportage resultaten: Landelijke Prevalentiemeting Zorgproblemen 2012. Maastricht: Maastricht University; 2012.

Halfens RJG, Meesterberends E, Meijers JJM, Du Moulin MFMT, van Nie NC, Neyens JCL, Schols JMGA. Rapportage resultaten: Landelijke Prevalentiemeting Zorgproblemen 2011. Maastricht: Datawyse / Universitaire Pers Maastricht; 2011.

\section{Published conference abstracts}

Meesterberends E, Halfens RJG, Lohrmann C, Schols JMGA. Pressure ulcer care in nursing homes: a comparison between the Netherlands and Germany. Journal of Nutrition, Health \& Aging 2013;17:S189. The 20th IAGG World Congress of Gerontology and Geriatrics, Seoul, Korea, June 23-27, 2013.

Meesterberends E, Halfens RJG, Lohrmann C, Schols JMGA. Pressure ulcer care in Dutch and German nursing homes. The $15^{\text {th }}$ Annual European Pressure Ulcer Advisory Panel meeting, Cardiff, United Kingdom, September 19-21, 2012.

Schols JMGA, Meesterberends E, Lohrmann C, Halfens RJG. Pressure ulcer incidence in nursing homes: Germany beats the Netherlands. European Geriatric Medicine 2012;3:S34. The $8^{\text {th }}$ Congress of the EUGMS, Brussels, September 26-28, 2012.

Meesterberends E, Halfens R, Lohrmann C, Schols J. Pressure ulcer care in Dutch and German nursing homes: a comparison of nurses' knowledge and patient characteristics. The $14^{\text {th }}$ Annual European Pressure Ulcer Advisory Panel meeting, Oporto, Portugal, August 31-September 2, 2011. 
Meesterberends E, Halfens RJG, Lohrmann C, Schols JMGA, de Wit R. Dissemination and implementation of pressure ulcer guidelines in Dutch nursing homes. The $13^{\text {th }}$ Annual European Pressure Ulcer Advisory Panel meeting, Birmingham, United Kingdom, September 1-3, 2010.

Meesterberends E, Halfens RJG, Lohrmann C, Schols JMGA. (2010) Verspreiding en implementatie van decubitus richtlijnen in Nederlandse verpleeghuizen. Congress decubitus stichting OZL, Kerkrade.

Meesterberends E, Halfens RJG, Lohrmann C, de Wit R, Schols JMGA. Pressure ulcer guideline development and dissemination in Europe. Journal of Clinical Nursing 2010;19:46. Fourth European Nursing Congress Older Persons: the Future of Care, Rotterdam, the Netherlands, October 4-7, 2010.

Meesterberends E, Halfens RJG, Lohrmann C, Schols JMGA, de Wit R. Dissemination and implementation of pressure ulcer guidelines in Dutch nursing homes. The $12^{\text {th }}$ Annual European Pressure Ulcer Advisory Panel meeting, Amsterdam, the Netherlands, September 3-5, 2009.

Meesterberends E, Tannen A, Lohrmann C, Schols JMGA, de Wit R, Halfens RJG. Pressure ulcer prevalence influencing factors - a model (PUP-IM). The $12^{\text {th }}$ Annual European Pressure Ulcer Advisory Panel meeting, Amsterdam, the Netherlands, September 3-5, 2009.

Meesterberends E, Halfens RJG, de Wit R, Lohrmann C. (2009) Pressure ulcer guideline development and dissemination in Europe. Journal of Nutrition, Health and Aging 2009;13. The $20^{\text {th }}$ IAGG World Congress, Paris, France, July 5-9, 2009.

Meesterberends E, Halfens RJG, de Wit R, Lohrmann C. Pressure ulcer guideline development and dissemination in Europe. EPUAP review 2008;9;48. $11^{\text {th }}$ Annual European Pressure Ulcer Advisory Panel meeting, Bruges, Belgium, September 4-6, 2008.

Meesterberends E, De Wit R, Dassen T, Halfens RJG. Explaining the differences in pressure ulcer prevalence in Europe by comparing guideline implementation processes, prevention and treatment. In: Proceedings of the Abstract book EDCNS, Vienna, Austria, September 7-8, 2007.

\section{Award}

First price for the best poster presentation at the European Academy of Nursing Science Summer School (Witten Herdecke, Germany, 2010) entitled 'Pressure ulcer care in Dutch and German nursing homes'. 
